SAND88-7115

Unlimited Release

$U C-253$

\title{
Evaluation of Saponite and Saponite/Sepiolite Fluids for Geothermal Drilling
}

N. Guven, D. J. Panfil, L. L. Carney

Department of Geosciences

Texas Tech University

Lubbock, TX 79409

Prepared by Sandia National Laboratories Albuquerque. New Mexico 87185 and Livermore. California 94550 for the United States Department of Energy under Contract DE-AC04-76DP00789

Printed February 1991

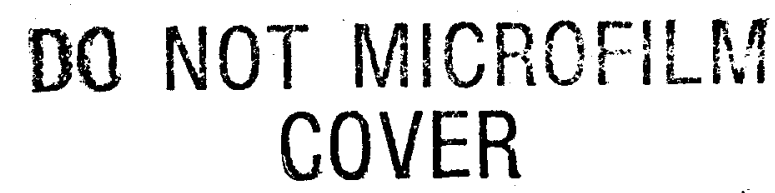




\section{DISCLAIMER}

This report was prepared as an account of work sponsored by an agency of the United States Government. Neither the United States Government nor any agency Thereof, nor any of their employees, makes any warranty, express or implied, or assumes any legal liability or responsibility for the accuracy, completeness, or usefulness of any information, apparatus, product, or process disclosed, or represents that its use would not infringe privately owned rights. Reference herein to any specific commercial product, process, or service by trade name, trademark, manufacturer, or otherwise does not necessarily constitute or imply its endorsement, recommendation, or favoring by the United States Government or any agency thereof. The views and opinions of authors expressed herein do not necessarily state or reflect those of the United States Government or any agency thereof. 


\section{DISCLAIMER}

Portions of this document may be illegible in electronic image products. Images are produced from the best available original document. 
Issued by Sandia National Laboratories, operated for the United States Department of Energy by Sandia Corporation.

NOTICE: This report was prepared as an account of work sponsored by an agency of the United States Government. Neither the United States Government nor any agency thereof, nor any of their employees, nor any of their contractors, subcontractors, or their employees, makes any warranty, express or implied, or assumes any legal liability or responsibility for the accuracy, completeness, or usefulness of any information, apparatus, product, or process disclosed, or represents that its use would not infringe privately owned rights. Reference herein to any specific commercial product, process, or service by trade name, trademark, manufacturer, or otherwise, does not necessarily constitute or imply its endorsement, recommendation, or favoring by the United States Government, any agency thereof or any of their contractors or subcontractors. The views and opinions expressed herein do not necessarily state or reflect those of the United States Government, any agency thereof or any of their contractors.

Printed in the United States of America. This report has been reproduced directly from the best available copy.

Available to DOE and DOE contractors from

Office of Scientific and Technical Information

PO Box 62

Oak Ridge, TN 37831

Prices available from (615) 576-8401, FTS 626-8401

Available to the public from

National Technical Information Service

US Department of Commerce

5285 Port Royal Rd

Springfield, VA 22161

NTIS price codes

Printed copy: A06

Microfiche copy: A01

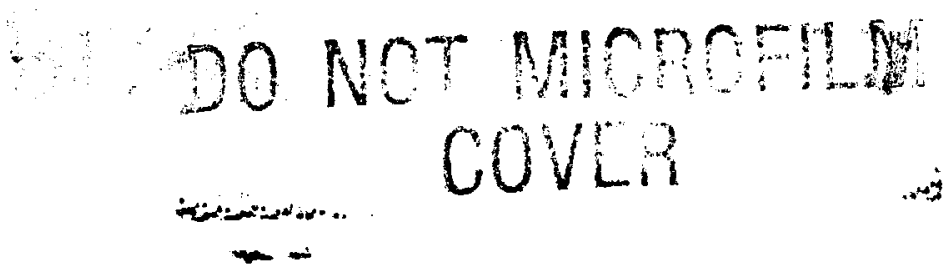




\title{
EVALUATION OF SAPONITE AND SAPONITE/SEPIOLITE FLUIDS FOR GEOTHERMAL DRILLING
}

\author{
By \\ N. Guven, D.J. Panfil, and L.L. Carney \\ Department of Geosciences, Texas Tech University \\ Lubbock, TX 79409
}

Submitted to

SANDIA NATIONAL LABORATORIES

Division 6252

Albuquerque, New Mexico 87185

MASTER

$m \cdot \cdots$

....... 


\section{ABSTRACT}

The rheology and other properties of drilling fluids containing saponite and a saponite-sepiolite mixture as the main viscosifier have been systematically evaluated in the temperature range of $300-600^{\circ} \mathrm{F}$ under appropriate confining pressures up to 16,000 psi. Saponite represents the magnesium analog of the clay mineral montmorillonite, which is the main constituent in conventional bentonite-based fluids. The fluid with $6 \%$ saponite exhibits a prominent viscosity enhancement at temperatures above $250^{\circ} \mathrm{F}$. This viscosity enhancement is easily controlled by salts and hydroxides of $\mathrm{Na}$ and $\mathrm{K}$. The addition of Na-polyacrylates (low- and high-molecular weight polymers) eliminates the viscosity anomaly of pure saponite fluids. These polymers also increase the filtration control of saponite.

The anomalous viscosity enhancement of saponite is significantly reduced by the addition of sepiolite (a clay mineral with a fibrous morphology). Sepiolite readily converts into thin films of smectite at $300^{\circ} \mathrm{F}$ and above which improves the filtration control of these fluids at high temperatures. This mixture demonstrates considerable potential for drilling geothermal wells. New fluids have been formulated by adding various polymers ( $\mathrm{Na}$ polyacrylates) to the saponite/sepiolite mixture. These formulations display excellent rheology and filtration control at elevated temperatures which will enhance performance in geothermal drilling. The properties of these fluids can be adjusted by controlling the relative concentrations of these constituents. 


\section{TABLE OF CONTENTS}

EXECUTIVE SUMMARY $\ldots \ldots \ldots \ldots \ldots \ldots \ldots \ldots \ldots \ldots \ldots \ldots \ldots, 1$

INTRODUCTION .................................... 14

METHODS OF INVESTIGATION $\ldots \ldots \ldots \ldots \ldots \ldots \ldots \ldots \ldots \ldots \ldots$

I. PROPERTIES AND RHEOLOGY OF SAPONITE

FLUIDS AT HIGH TEMPERATURES $\ldots \ldots \ldots \ldots \ldots \ldots \ldots, 23$

II. PROPERTIES AND RHEOLOGY OF SAPONITE/

SEPIOLITE FLUIDS AT HIGH TEMPERATURES .......... 46

III. NEW FLUID FORMULATIONS $\ldots \ldots \ldots \ldots \ldots \ldots \ldots \ldots . . . . . .60$

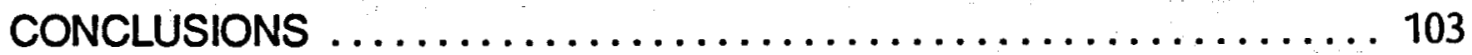

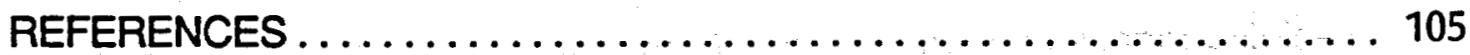




\section{EXECUTIVE SUMMARY}

A systematic investigation of water-based drilling fluids composed of saponite and a saponite-sepiolite mixture have been carried out under conditions prevailing in geothermal environments. The meological behavior and other mud properties necessary to maintain optimum performance during rotary drilling have been evaluated at high temperatures and pressures in chemically complex environments similar to those in geothermal wells. The appropriate slurries have been prepared at 6 and $8 \%$ concentrations, which are comparable to fluids used under realistic field conditions (not counting drill solids and weighting materials). The commonly encountered formation salts and hydroxides such as $\mathrm{Na}, \mathrm{Ca}$, and $\mathrm{K}$ have been added at $1 \%$ concentrations to the above fluid systems. Similarly, the contribution of various organic mud additives such as lignite, lignosulfonate, and polymers (high-and low-molecular weight sodium polyacrylates) have also been evaluated in the high temperature regime.

These fluid systems were autoclaved in the temperature range of $300-600^{\circ} \mathrm{F}$ under the appropriate confining pressures up to $16,000 \mathrm{psi}$. High temperature viscosity profiles have been measured with a Fann $50 \mathrm{C}$ rotational-type concentric viscometer before and after autoclaving. Other fluid properties such as plastic viscosity, gel strength, yield point, $\mathrm{pH}, \mathrm{CEC}$, surface area, fluid loss, and filter cake thickness have also been determined, and are summarized in Tables I-III. Precipitation of new mineral phases have been characterized with $x$-ray diffraction and electron microscopy, and correlated with the rheological and filtration properties of these fluids. The major result of these investigations are summarized below. 


\section{Saponite-Based Fluids}

1. The properties of $6 \%$ saponite fluids are summarized in Table 1.

Viscosity profiles of saponite-based fluids exhibit an anomalous enhancement between 200 and $450^{\circ} \mathrm{F}$, and their maxima increase with subsequent levels of autoclaving. In fact, the fluid autoclaved at $600^{\circ} \mathrm{F}$ reaches a maximum viscosity of $165 \mathrm{cp}$ at $425^{\circ} \mathrm{F}$. Saponite has extremely good fluid loss properties (low). The API filtrate remains relatively stable at $8 \mathrm{ml} / 30 \mathrm{~min}$ for all temperatures, and the HP.HT filtrate ranges from $36 \mathrm{ml} / 30$ min for the unautoclaved fluid to $20 \mathrm{ml} / 30 \mathrm{~min}$ at $500^{\circ} \mathrm{F}$.

2. The addition of KOH significantly reduces the viscosity of saponite fluids. The presence of $\mathrm{KOH}$ completely eliminates the viscosity anomaly (i.e. enhancement at high temperature) in all of the saponite fluids except for the fluid autoclaved at $400^{\circ} \mathrm{F}$. The presence of the $\mathrm{K}+$ ion seems to promote a face-to-face association of clay particles, which reduces the exposed surface area and subsequently reduces viscosity. As determined by $x$-ray diffraction, saponite remains stable up to and including the fluid autoclaved at $500^{2} \mathrm{~F}$. Saponite does begin to breakdown in the fluid autoclaved at $600^{\circ} \mathrm{F}$, whereas Wyoming bentonite was found to be unstable in the presence of $\mathrm{KOH}$ at high temperatures. The main mineral component in bentonite fluids was a $\mathrm{K}$-feldspar (sanidine) that forms at the expense of smectite and is rheologically inert. In the saponite fluid only a small amount of tremolite, a fibrous amphibole, was found at $600^{\circ} \mathrm{F}$. Although both saponite and Wyoming bentonite have very high fluid losses in the presence of potassium, the K-ion has a more detrimental effect on Wyoming bentonite.

3. The addition of $1 \% \mathrm{Na}_{2} \mathrm{CO}_{3}$ has a less dramatic affect upon the fluid properties of saponite as compared with Wyoming bentonite. Montmorillonite (main component of Wyoming bentonite) readily dissolves and leads to the 
SIGNIFICANT PROPERTIES OF FLUIDS CONTAINING 6\% SAPONITE AND 1\% ADDITIVES

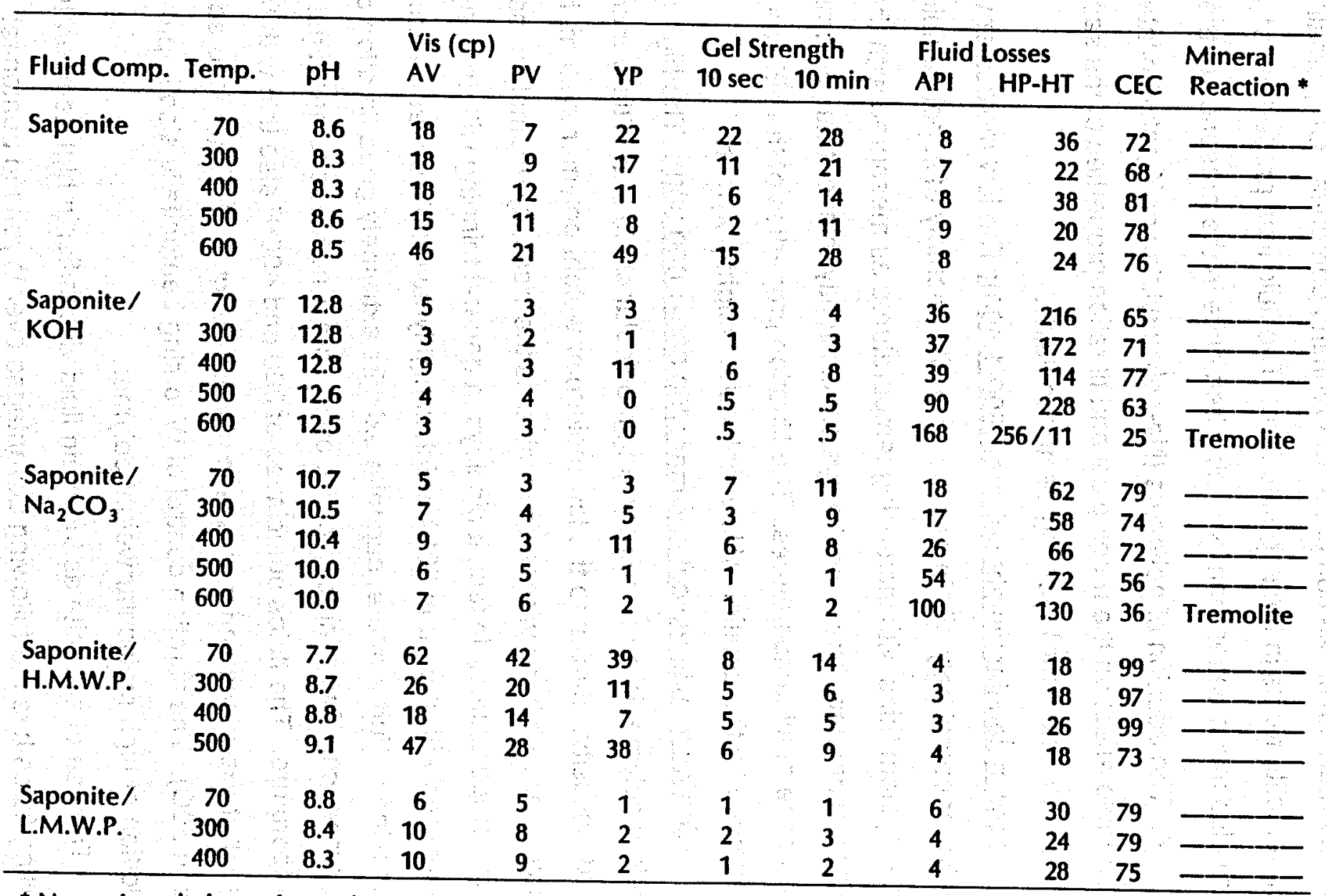

* New mineral phases formed in the fluid 
precipitation of albite (a Na-plagioclase) at high temperatures. The saponite system remains relatively stable in the presence of soda ash at all temperature levels as compared to Wyoming bentonite. Only small amounts of tremolite forms in the saponite fluid. The fluid loss properties of saponite are also much better than Wyoming bentonite in the presence of the $\mathrm{Na}_{2} \mathrm{CO}_{3}$.

4. The addition of polymers (Na-polyacrylates or K-polyacrylates) has a favorable effect on the rheological and filtration properties of the saponite fluid as was the case for Wyoming bentonite fluids.

Low molecular weight polymer (900-1.400): The low molecular weight polymer completely eliminates the viscosity anomaly of saponite fluids. The fluid system thins with increasing temperatures as measured with the Fann $50 \mathrm{C}$ viscometer. The saponite system is slightly thinner than Wyoming bentonite at all temperatures. The filtration properties of the fluid have been improved by the addition of low molecular weight polymer.

High molecular weight polymer (750.000-1.000.000): The high molecular weight polymer is an extremely long molecular chain that initially increases fluid viscosity. Similar to the low molecular weight polymer system, high molecular weight polymer also eliminates the viscosity anomaly of saponite at high temperatures. In fact, it displays a general thinning with temperature (as measured with the Fann $50 \mathrm{C}$ ) which is highly favorable under realistic field conditions. Furthermore, saponite exhibits extremely good filtration control in its presence. Wyoming bentonite, on the other hand, becomes a gel at room temperature. The fluids autoclaved at 300 and $40^{\circ} \mathrm{F}$ also thin with temperature, but experience an increase in viscosity above 4009F (measured with Fann $50 \mathrm{C}$ ). The filtration control of Wyoming bentonite is also improved by the addition of high molecular weight polymer.

The use of saponite as the main fluid viscosifier in high temperature drilling fluids has the following advantages over Wyoming bentonite: (a) in all 
cases, saponite has better filtration control than Wyoming bentonite, (b) saponite remains stable at high temperatures in the presence of contaminants, whereas Wyoming bentonite is rather unstable and leads to the precipitation of new mineral phases in large amounts, which are inert toward fluid properties, and (c) the addition of Na-polyacrylates has a more favorable affect upon the properties of saponite than Wyoming bentonite.

\section{Saponite-Sepiolite Based Drilling Fluids}

Fluids containing a 1:1 mixture of saponite and sepiolite have been evaluated in the high temperature regime. The properties of these fluids are summarized in Table II, and they are briefly described below.

1. Sepiolite is a clay mineral with a chemical composition similar to saponite, however, it has a non-swelling structure, a fibrous morphology and does not carry an excess layer charge. Therefore, the addition of sepiolite to the saponite system modifies the anomalous viscosity enhancement at elevated temperatures. Sepiolite has intercrystalline channels within its structure, therefore as expected, the API and HP-HT fluid losses are higher than the pure saponite system. Seplolite has a relatively delicate structure and readily converts to smectite under hydrothermal conditions at elevated temperatures. Therefore, as sepiolite is converted to smectite, the filtration control properties and the rheology of the fluids improves considerably.

2. Salts and hydroxides of calcium are extremely detrimental to mud properties of saponite-sepiolite fluids. In fact, the addition of $1 \% \mathrm{CaCl}_{2}$ reduces the viscosity below $4 \mathrm{cp}$ at all temperature levels in the laminar flow regime. Other rheological properties (plastic viscosity, yield point, and gel 
TABLE ॥

SIGNIFICANT PROPERTIES OF THE FLUIDS CONTAINING 6\% SAPONITE-SEPIOLITE AND 1\% ADDITIVES

\begin{tabular}{|c|c|c|c|c|c|c|c|c|c|c|c|}
\hline \multirow[b]{2}{*}{ Fluid Comp. } & \multirow[b]{2}{*}{ Temp. } & \multirow[b]{2}{*}{$\mathrm{pH}$} & \multicolumn{2}{|c|}{ Vis (cp) } & \multirow[b]{2}{*}{$Y P$} & \multicolumn{2}{|c|}{ Gel Strength } & \multicolumn{2}{|c|}{ Fluid Losses } & \multirow[b]{2}{*}{ CEC } & \multirow{2}{*}{$\begin{array}{c}\text { New } \\
\text { Minerals* }\end{array}$} \\
\hline & & & AV & PV & & $10 \mathrm{sec}$ & $10 \mathrm{~min}$ & API & HP-HT & & \\
\hline \multirow{5}{*}{$\begin{array}{l}\text { Saponite- } \\
\text { Sepiolite }\end{array}$} & 70 & 9.1 & 27 & 5 & 44 & 36 & 47 & 18 & 90 & 49 & \\
\hline & 300 & 8.0 & 10 & 5 & 10 & 10 & 15 & 16 & 76 & 76 & \multirow{4}{*}{$\begin{array}{l}\text { Smectite } \\
\text { Smectite } \\
\text { Smectite } \\
\text { Smectite }\end{array}$} \\
\hline & 400 & 8.0 & 12 & 10 & 3 & 3 & 11 & 16 & 56 & 71 & \\
\hline & 500 & 8.1 & 25 & 13 & 23 & 17 & 29 & 14 & 48 & 79 & \\
\hline & 600 & 8.3 & 28 & 10 & 35 & 13 & 30 & 15 & 40 & 63 & \\
\hline Saponite- & 70 & 7.5 & 7 & 2 & 9 & 5 & 7 & 72 & ** & 38 & \\
\hline Sepiolite/ & 300 & 6.9 & 4 & 2 & 3 & 3 & 10 & 114 & ** & 45 & \multirow{4}{*}{$\begin{array}{l}\text { Smec, Cal } \\
\text { Smec, Cal } \\
\text { Smectite } \\
\text { Smectite }\end{array}$} \\
\hline \multirow[t]{3}{*}{$\mathrm{CaCl}_{2}$} & 400 & 6.8 & 4 & 2 & 3 & 3 & 7 & 102 & ** & 60 & \\
\hline & 500 & 6.7 & 2 & 1 & 2 & 1 & 1 & 170 & ** & 57 & \\
\hline & 600 & 7.0 & 2 & 1 & 1 & .5 & 1 & - & ** & 49 & \\
\hline Saponite- & 70 & 12.3 & 6 & 2 & 7 & 3 & 4 & 208 & ** & 23 & Calcite \\
\hline Sepiolite/ & 300 & 11.3 & 10 & 3 & 14 & 10 & 13 & 154 & ** & 42 & Smec, Cal \\
\hline \multirow[t]{3}{*}{$\mathrm{Ca}(\mathrm{OH})_{2}$} & 400 & 10.0 & 2 & 1 & 1 & .5 & 1 & 136 & \multirow{3}{*}{$\begin{array}{r}* * \\
180\end{array}$} & 52 & \multirow{3}{*}{$\begin{array}{l}\text { Smec,Tober, } \\
\text { Smectite } \\
\text { Smectite }\end{array}$} \\
\hline & 500 & 9.6 & 2 & 2 & 0 & .5 & .5 & 96 & & 49 & \\
\hline & 600 & 9.3 & 2 & 1 & 1 & .5 & .5 & 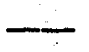 & & 40 & \\
\hline \multirow{5}{*}{$\begin{array}{l}\text { Saponite- } \\
\text { Sepiolite/ } \\
\mathrm{KCl}\end{array}$} & 70 & 8.4 & 26 & 7 & 38 & 23 & 30 & 54 & 194 & 46 & \\
\hline & 300 & 7.4 & 9 & 3 & 11 & 14 & 38 & 62 & 204 & 51 & \multirow{4}{*}{$\begin{array}{l}\text { Smectite } \\
\text { Smectite } \\
\text { Smectite } \\
\text { Tremolite }\end{array}$} \\
\hline & 400 & 7.5 & 10 & 4 & 12 & 14 & 40 & 52 & 138 & 66 & \\
\hline & 500 & 7.5 & 12 & 4 & 16 & 19 & 46 & 40 & 144 & 64 & \\
\hline & 600 & 7.7 & 6 & 2 & 7 & 7 & 17 & 56 & 182 & 55 & \\
\hline \multirow{5}{*}{$\begin{array}{l}\text { Saponite- } \\
\text { Sepiolite/ } \\
\text { KOH }\end{array}$} & 70 & 12.7 & 5 & 2 & 5 & 6 & 10 & 43 & $* *$ & 50 & \\
\hline & 300 & 12.3 & 3 & 2 & 2 & .5 & 2 & 51 & ** & 68 & \multirow{4}{*}{$\begin{array}{l}\text { Smec, Cal } \\
\text { Smectite } \\
\text { Smectite } \\
\text { Smec,l/S, Feld }\end{array}$} \\
\hline & 400 & 11.7 & 5 & 4 & 2 & .5 & 12 & 49 & 98 & 59 & \\
\hline & 500 & 10.9 & 3 & 3 & 0 & .5 & 1 & 42 & ** & 48 & \\
\hline & 600 & 10.4 & 3 & 3 & 0 & .5 & 1 & 86 & *** & 24 & \\
\hline
\end{tabular}

* New mineral phases formed in the fluid: Smec: smectite formed from sepiolite, Cal: calcite, Tober: tobermorite, I/S: illite/smectite mixed layers, Feld: feldspars, Trem: tremolite.

** The fluid loss is extermely high ( $>250 \mathrm{ml} / 30 \mathrm{~min}$ ), and blowout occurs. 
TABLE II. CONTINUED

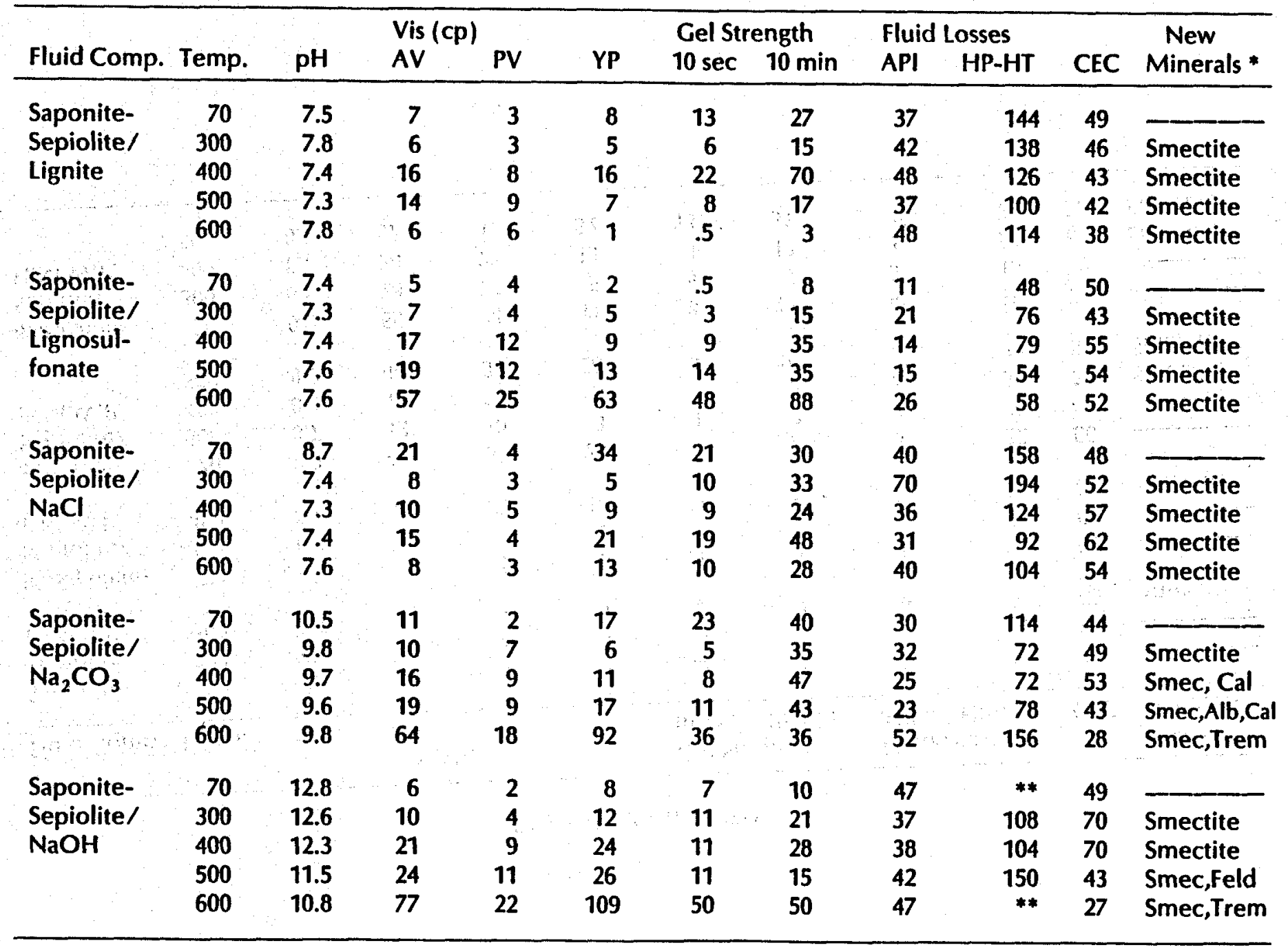


TABLE II. CONTINUED

\begin{tabular}{|c|c|c|c|c|c|c|c|c|c|c|c|}
\hline \multirow[b]{2}{*}{ Fluid Comp. } & \multirow[b]{2}{*}{ Temp. } & \multirow[b]{2}{*}{$\mathrm{pH}$} & \multicolumn{2}{|c|}{ Vis $(c p)$} & \multirow[b]{2}{*}{ YP } & \multicolumn{2}{|c|}{ Gel Strength } & \multicolumn{2}{|c|}{ Fluid Losses } & \multirow[b]{2}{*}{ CEC } & \multirow{2}{*}{$\begin{array}{c}\text { New } \\
\text { Minerals }\end{array}$} \\
\hline & & & AV & PV & & $10 \mathrm{sec}$ & $10 \mathrm{~min}$ & API & HP-HT & & \\
\hline Saponite- & 70 & 9.3 & 4 & 3 & 1 & .5 & 1 & 7 & 50 & 59 & - \\
\hline Sepiolite/ & 300 & 8.9 & 5 & 4 & 1 & .5 & 1 & 5 & 35 & 61 & $-\ldots$ \\
\hline L.M.W.P. & 400 & 8.7 & 7 & 7 & 1 & .5 & 1 & 6 & 34 & 69 & Smectite \\
\hline 8\%Saponite- & 70 & 9.4 & 5 & 5 & 0 & .5 & 1 & 4 & 36 & 59 & $\longrightarrow-1$ \\
\hline Sepiolite/ & 300 & 8.9 & 8 & 7 & 2 & 1 & 1 & 5 & 25 & 62 & $-1-1$ \\
\hline L.M.W.P. & 400 & 8.4 & 30 & 22 & 16 & 3 & 5 & 5 & 30 & 66 & Smectite \\
\hline Saponite- & 70 & 8.3 & 48 & 35 & 26 & 4 & 7 & 5 & 32 & 66 & \\
\hline Sepiolite/ & 300 & 8.7 & 12 & 10 & 3 & 1 & 2 & 4 & 22 & 66 & $-\cdots$ \\
\hline \multirow[t]{2}{*}{ H.M.W.P. } & 400 & 8.4 & 13 & 11 & 3 & 1 & 2 & 5 & 30 & 78 & Smectite \\
\hline & 500 & 8.2 & 40 & 30 & 20 & 4 & 10 & 6 & 30 & 84 & Smectite \\
\hline 8\% Saponite- & 70 & 9.2 & 65 & 44 & 41 & 8 & 15 & 4 & 16 & 73 & $-\cdots$ \\
\hline Sepiolite/ & 300 & 8.8 & 28 & 25 & 5 & 5 & 9 & 3 & 16 & 70 & \\
\hline \multirow[t]{2}{*}{ H.M.W.P. } & 400 & 8.7 & 28 & 21 & 13 & 4 & 12 & 3 & 24 & 69 & Smectite \\
\hline & 500 & 8.4 & 67 & 41 & 52 & 13 & 31 & 4 & 22 & 77 & Smectite \\
\hline
\end{tabular}


strength) and filtration control are also extremely poor in the presence of Ca-ions. As the $\mathrm{Ca}$-ion is incorporated into the clay structure (i.e., interlayer cation), it promotes stronger bonding between smectite layers, leading to the formation of flocs. This mode of aggregation reduces surface area and dispersion of the clays which, in tum, reduces fluid rheology and filtration control.

3. The addition of potassium chloride and potassium hydroxide also has a significant effect upon the fluid properties of saponite-sepiolite slurries, and it appears, that $\mathrm{KOH}$ is more detrimental than $\mathrm{KCl}$. The addition of $\mathrm{KCl}$ has reduced the viscosity at all temperatures, and for the most part, eliminates or considerably reduces the anomalous enhancement present in the pure saponite-sepiolite system. Similar to the saponite/KOH system, the saponitesepiolite/KOH system is relatively thin in viscosity at all temperatures. Only the fluid autoclaved at $300^{\circ} \mathrm{F}$ experiences a noticeable viscosity enhancement. At higher temperatures ( 500 and $600^{\circ} \mathrm{F}$ ), the presence of the K-ion in the saponite-sepiolite/ KOH system seems to promote the conversion of saponite to illite / smectite mixed-layers, and K-feldspar. The precipitation of inert mineral phases are responsible for the poor fluid properties.

4. Salts and hydroxides of sodium are less detrimental to the fluid properties of saponite-sepiolite than the contaminants previously discussed. The presence of sodium in solution leads to a higher degree of dispersion of smectite particles. This is reflected by higher viscosities, lower fluid losses, and relatively higher CEC's and surface areas compared with the fluids saturated with $\mathrm{Ca}$ - or $\mathrm{K}$-ions. Fluids containing $1 \% \mathrm{NaCl}$ experience the most significant viscosity anomalies. However, in all cases the $\mathrm{Na}$-ion has reduced the viscosity enhancement present in the pure saponite-sepiolite fluids. Precipitation of a new mineral phase, tremolite, in the presence of $\mathrm{Na}_{2} \mathrm{CO}_{3}$ and $\mathrm{NaOH}$ are responsible for the significant increase in viscosity at room 
temperature for the fluids autoclaved at $600^{\circ} \mathrm{F}$. The saponite-sepiolite system offers a more stable fluid viscosity with increasing temperatures (as measured with the Fann $50 \mathrm{C}$ ) than the pure saponite system in the presence of $\mathrm{Na}_{2} \mathrm{CO}_{3}$. With exception of the saponite-sepiolite $/ \mathrm{Na}_{2} \mathrm{CO}_{3}$ fluid autoclaved at $600^{\circ} \mathrm{F}$, other rheological properties are also more favorable than in the pure saponite system.

5. The addition of various organic compounds such as lignite, lignosulfonate, and polymers have the following effects on saponite-sepiolite fluids.

Lignite: The addition of lignite has a notable effect upon the fluid properties of saponite-sepiolite. It controls the extent of the anomalous viscosity enhancement and is better than with bentonite fluids. The fluids remain below $17 \mathrm{cp}$ throughout the appropriate temperature range. However, contrary to the popular belief of practical field applications, the addition of lignite does not improve filtration control. Due to the evolution of $\mathrm{CO}_{2}$ gas, this system experiences a higher fluid loss than the pure saponite-sepiolite system. It is apparent that lignite has affected the dispersion of clay particles. This can be implied from the existence of low surface areas.

Lignosulfonate: The addition of lignosulfonate completely eliminates the viscosity maxima for the unautoclaved and fluid autoclaved at $300^{\circ} \mathrm{F}$. The saponite-sepiolite fluids display rather low viscosities up to $300^{\circ} \mathrm{F}$, but become increasingly viscous with high temperatures. It appears that lignosulfonate begins to decompose at and above $400^{\circ} \mathrm{F}$. Filtration control is better than the lignite system, but still exhibits higher fluid losses than pure saponite-sepiolite. The fluid is slightly above neutral with a pH ranging from 7.3 to 7.6. The clay minerals do not undergo any major reactions at low $\mathrm{pH}$ values.

SPA polymers with low molecular weight $(900-1,400)$ : The addition of low molecular weight polymer completely eliminates the viscosity anomaly of 
saponite-sepiolite fluids. Filtration control is improved considerably. Low molecular weight polymer inhibits the conversion of sepiolite to smectite at 300'F; however, it begins to decompose above this temperature. Therefore, as the polymer begins to decompose, sepiolite starts to convert into smectite which improves fluid loss properties.

SPA polymers with high molecular weight (750.000-1.000.000): High molecular weight polymers also control the rheological properties of saponite-sepiolite fluids at high temperatures, and have a favorable effect upon filtration control. High molecular weight polymer also inhibits the conversion of sepiolite to smectite at $300^{\circ} \mathrm{F}$, but begins to decompose above $300^{\circ} \mathrm{F}$.

The contributions of sepiolite to the saponite system offer the following advantages: (a) it modifies the anomalous viscosity enhancement of the pure saponite system at elevated temperatures, and (b) the addition of sepiolite offers more stable rheological properties in the presence of common salt contaminants such as in sea water or salt water.

\section{New Fluid Formulations}

The above investigations of saponite and saponite - sepiolite fluids lead to the formulations of new fluids for geothermal drilling. These new fluids contain a 1:1 mixture of saponite and sepiolite as the main viscosifier, various amounts of high- and low-molecular weight polymers (Na-polyacrylates) and weighting material (barite). The fluids are formulated as indicated below, and their properties are summarized in Table III.

\section{Fluid A:}

$25 \mathrm{lbs} / \mathrm{bbl}$ Saponite-Sepiolite

$5 \mathrm{lbs} / \mathrm{bbl}$ High molecular weight polymer

$1 \mathrm{lbs} / \mathrm{bbl}$ Low molecular weight polymer 


\section{Fluid B:}

$25 \mathrm{lbs} / \mathrm{bb}$ Saponite-Sepiolite

$5 \mathrm{lbs} / \mathrm{bbl}$ High molecular weight polymer

$1 \mathrm{lbs} / \mathrm{bb} /$ Low molecular weight polymer

$12 \mathrm{lbs} / \mathrm{gal}$ (weighted with barite)

Fluid C:

$25 \mathrm{lbs} / \mathrm{bbl}$ Saponite-Sepiolite

$5 \mathrm{lbs} / \mathrm{bbl} \mathrm{High} \mathrm{molecular} \mathrm{weight} \mathrm{polymer}$

$1 \mathrm{lbs} / \mathrm{bbl}$ Low molecular weight polymer

$14 \mathrm{lbs} / \mathrm{gal}$ (weighted with barite)

Fluid D:

$25 \mathrm{lbs} / \mathrm{bb} /$ Saponite-Sepiolite

$5 \mathrm{lbs} / \mathrm{bbl} \mathrm{High} \mathrm{molecular} \mathrm{weight} \mathrm{polymer}$

$2 \mathrm{lbs} / \mathrm{bbl}$ Low molecular weight polymer

$14 \mathrm{lbs} / \mathrm{gal}$ (weighted with barite)

\section{Fluid E:}

$25 \mathrm{lbs} / \mathrm{bb} /$ Saponite-Sepiolite

$5 \mathrm{lbs} / \mathrm{bbl} \mathrm{High} \mathrm{molecular} \mathrm{weight} \mathrm{polymer}$

$3 \mathrm{lbs} / \mathrm{bbl}$ Low molecular weight polymer

$16 \mathrm{lbs} / \mathrm{bbl}$ (weighted with barite)

These fluids maintain favorable rheological properties in the temperature range of $70-600^{\circ} \mathrm{F}$ and may be adjusted in order to obtain desirable values by varying the relative clay concentrations (saponite-sepiolite). These muds exhibit exceptional fluid loss properties at all temperature levels. 
TABLE III

SIGNIFICANT PROPERTIES OF THE FORMULATED FLUIDS

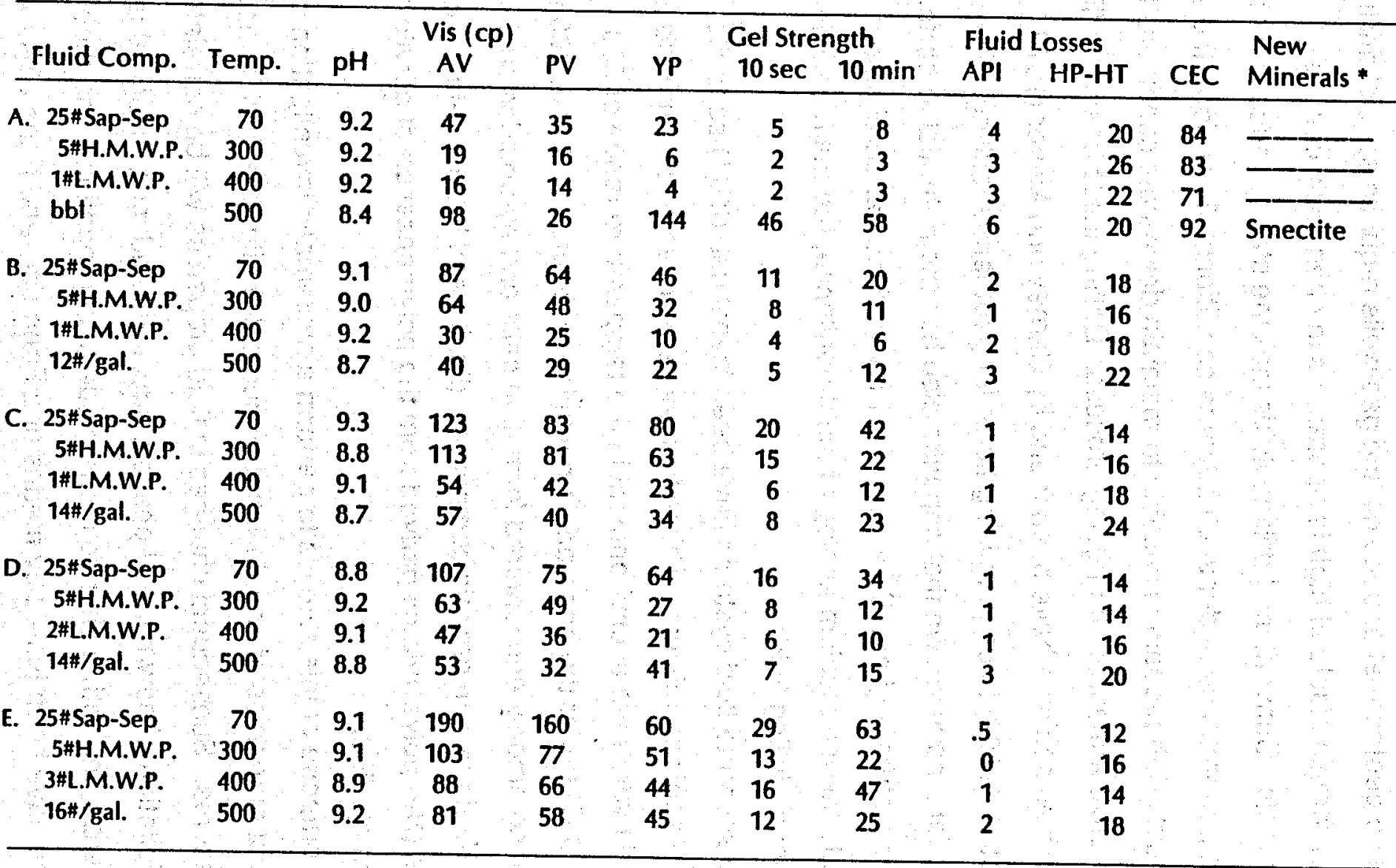

\#: pounds per barrel; * new mineral phases formed in the fluid. 


\section{INTRODUCTION}

Drilling geothermal or deep oil and gas wells requires special drilling fluids that must remain stable at high temperatures in chemically complex environments. Conventional drilling fluids lack the stability necessary to maintain optimum performance under such adverse conditions. Therefore, the search for drilling fluids with properties suitable to maintain down-hole conditions in an extreme environment is an ongoing process. Drilling fluids based on fibrous clays such as sepiolite have been found by Carney and Meyer (1976), and Guven et al. (1982) to be promising fluids for geothermal drilling. Our preliminary investigations have shown that saponite also has the potential to perform in the high temperature regime. Saponite (a 2:1 layered trioctahedral smectite) represents the magnesium analog of montmorillonite, the main constituent in conventional drilling fluids.

Two separate fluid systems have been investigated: (1) saponite and (2) a saponite - sepiolite mixture. These fluid systems have been exposed to a simulated hydrothermal environment in the temperature range of $300-600^{\circ} \mathrm{F}$ $\left(149-316^{\circ} \mathrm{C}\right)$ under the appropriate confining pressures up to $16,000 \mathrm{psi}$. The effects of commonly encountered formation salts and hydroxides such as of $\mathrm{Na}$, $\mathrm{Ca}$, and $\mathrm{K}$, along with organic compounds (lignite and lignosulfate), and various polymers ( $\mathrm{Na}$ - polyacrylates derived from the polymerization of acrylic acid) have also been studied.

The purpose of this study is to perform a systematic investigation of the rheological properties of certain water-based drilling fluids at high temperatures and pressures. Subsequent changes in fluid properties will be correlated with the precipitation of new mineral phases, structural and morphological features of clay minerals and with a change in the mode of aggregation. The rheological properties have been tested by means of a Fann $50 \mathrm{C}$ and Fann 35A rotational viscometers. The characterization of solid particles in these fluids has been 
determined by $x$-ray diffraction and electron microscopy.

Finally, based on the understanding and comparison of these fluid systems, new fluids for geothermal drilling have been formulated and tested within the appropriate temperature range. 


\section{METHODS OF INVESTIGATION}

Clay-based drilling fluids consisting of saponite and a saponite - sepiolite mixture have been prepared at 6 and $8 \%$ concentrations in deionized water. The appropriate clay weight-volume was mixed for 20 minutes in a Hamilton Beach blender and allowed to hydrate overnight in order to permit the clay to reach optimum dispersion. The fluids were autoclaved in the temperature range of $300-600^{\circ} \mathrm{F}$ under the appropriate confining pressures up to 16,000 psi. After autoclaving, the rheological and filtration properties of the fluids were tested by means of a Fann $50 \mathrm{C}$ high pressure-high temperature viscometer, Fann 35A viscometer, Baroid high pressure-high temperature (HP-HT) filter press, and Baroid standard (API) filter press. Subsequent fluid systems containing $1 \%$ concentrations of salts and hydroxides of $\mathrm{Na}, \mathrm{K}$, and $\mathrm{Ca}$, organic compounds (lignite and lignosulfonate), and various polymers (Na-polyacrylates or K-polyacrylates for low sodium systems) were also tested by the above procedure. The specifics of these experiments are described in the following:

\section{High Temperature-High Pressure Auteclave}

The autoclave was designed and manufactured by Autoclave Engineers, Erie, Pennsylvania. The cell itself has a sample capacity of $800 \mathrm{ml}$ and is capable of reaching $1,000^{\circ} \mathrm{F}$ and $17,500 \mathrm{psi}$. The autoclave uses Autoclave Engineers self-supported closure metal seals, which press the seal ring against the autoclave body. Slight variation of the angles between contact surfaces of the seal ring and body results in a line contact between the two surfaces. The cell was used for static heating of clay slurries at high temperatures $\left(300-600^{\circ} \mathrm{F}\right)$ under the appropriate confining pressures up to 16,000 psi. Pressure is initially produced by a Haskel air driven liquid pump, model \#DHW 300. The temperature is maintained by an Autoclave Engineers temperature controller which consists of a Barber-Colman, Model 520 analog 
and digital set point controllers. Temperature and pressure are monitored and recorded automatically by a Barber-Colman single pen strip chart recorder in degrees Fahrenheit and pounds per square inch, respectively.

The sample was heated at a rate of $125^{\circ} \mathrm{F} /$ hour to the desired temperature and pressure, at which point it was maintained for 6 hours. The autoclave is cooled to room temperature in approximately 14 hours. The sample was transferred for further testing.

A detailed description of the autoclave has been documented by Guven et al. (1982).

\section{Eann $50 \mathrm{C}$ Viscometer}

The Fann $50 \mathrm{C}$ viscometer is a rotational-type concentric viscometer. This viscometer is equipped with a standard rotor cup (sample capacity of $50 \mathrm{ml}$ ) that has a rotational speed of 0-600 RPM. The viscosity is calibrated by shearing a thin film of fluid between concentric cylinders, as the outer cylinder is rotated at a constant rate. Shear stress is measured in terms of deflection of the inner cylinder or bob, which is suspended by a torsion spring. The system is completely sealed from the atmosphere to prevent dehydration of the sample.

The sample is heated at a constant rate for two hours up to $500^{\circ} \mathrm{F}$ by an oil bath under a constant pressure of $750 \mathrm{psi}$, and a shear rate of $1022 \mathrm{sec}^{-1}$. The temperature and viscosity are automatically recorded by a Houston Instruments' two-pen, bichannel strip recorder. The viscosity vs. temperature variations are given in the form of a rheogram for each fluid.

\section{Eann $35 \mathrm{~A}$ Viscometer}

The Fann 35A viscometer is also a rotational-type concentric viscometer, which operates on the same principle as the Fann 50C. However, the Fann $35 \mathrm{~A}$ measures apparent and plastic viscosity, yield point and gel strength at 
room temperature and atmospheric pressure. The Fann $35 \mathrm{~A}$ is operated by a two-speed, 110 volt synchronous motor, which enables it to operate at six rotation speeds.

The plastic viscosity and yield point can be calculated very simply from two direct dial readings; one at 600 RPM and the other at 300 RPM. Savins and Roper (1954) have determined that the plastic viscosity is the difference between the dial readings at 600 and 300 RPM, respectively. The yield point can be calculated by subtracting the plastic viscosity from the 300 RPM reading. The following equations give plastic viscosity in centipoise and yield point in pounds per 100 square feet.

The apparent viscosity (shear stress divided by shear rate) is calculated when the following information is known:

1 dial unit $=5.11$ dynes $/ \mathrm{cm}^{2}$ (shear stress)

$1 \mathrm{RPM}=1.7033 \mathrm{sec}^{-1}$ (shear rate) with 300

centipoise per unit per RPM

Therefore, the following equations apply:

Apparent viscosity $=300 \times$ units read at $R P M+R P M$

Because the standard method of measuring apparent viscosity is at a 600 RPM rotation, the equation may be simplified to:

Apparent viscosity = units read at $600 \mathrm{RPM}+2$

In order to fully comprehend these calculations, it is appropriate to discuss some basic drilling fluid-flow properties.

Plastic viscosity: Plastic viscosity is the shearing stress in excess of yield point that will induce a unit rate of shear (Magcobar, 1972). Plastic viscosity is that part of flow resistance caused by mechanical friction which occurs: (1) between the solids in the mud, (2) between the solids and the liquid that surrounds them, and (3) with the shearing of the liquid itself. Therefore, for all practical purposes, plastic viscosity depends on the concentration of mud solids. 
Yield point: Yield point is the second component of resistance to flow in a drilling fluid. It is a measurement of the electro-chemical or attractive forces in a fluid under flow conditions. These forces are a result of negative and positive charges located on or near the particle surfaces, and are dependent on: (1) the surface properties of the mud solids, (2) volume concentration of the solids, and (3) the electro-chemical environment of these solids, particularly the concentration and type of ions present. Yield point may be regulated by the use of chemical additives. Therefore, it dictates the nature and degree of treatment necessary to maintain a desirable fluid viscosity (Magcobar, 1972).

Gel strength: Gel strength is a measurement of the thixotropic properties of a drilling fluid under static or non-flow conditions. Similar to yield point, gel strength is a measure of the electro-chemical attractive forces between solid particles. However, gel strength should not be confused with yield point as it is a measurement under flow conditions. Because yield point and gel strength are a result of the flocculation forces of a thixotropic fluid, as yield point decreases, gel strength will generally decrease.

Gel strengths are classified as two types; a strong (progressive) gel strength or a weak (fragile) gel strength. Strong gel strengths are typically associated with thicker muds that are hard to break upon initial rotation, such as bentonites muds. Gel strength will normally increase with stagnation time. On the other hand, weak gel strengths are associated with thin muds that are easily broken with initial rotation, and increase slightly with stagnation time (saponite/sepiolite muds). According to Roseland (1980), fragile gels are the most desirable.

Gel strengths are measured by the Fann 35A at a rotational speed of 3 RPM. The drilling fluid is allowed to stagnate for 10 seconds and 10 minutes respectively, at which time the outer cup is rotated at 3 RPM and the maximum deflection of the dial is recorded. Gel strengths are recorded in pounds per 
100 square feet.

\section{Baroid Standard Filter Press}

The Baroid Standard Filter Press, which determines API filtrate and cake thickness under static conditions, consists of a fluid cup supported by a frame, a filtering medium, and a pressurized nitrogen gas cylinder and regulator. $A$ graduated cylinder is used to measure the discharged filtrate. $100 \mathrm{psi}$ is applied to a column of fluid for 30 minutes, or until blowout occurs, upon which the filtrate is measured and recorded. The mud cake deposited on the filter paper is measured in thirty-seconds of an inch.

Filtration properties of drilling muds determine the ability of the solid phase in the fluid to form a thin impervious cake of filtered solids. Even though the cake thickness is related to filter loss, it is ultimately dependent on the concentration of solids in the mud and on the amount of water retained in the cake (Gray et al., 1980). Dynamic filtration is more important than static filtration, and unfortunately there is no relationship between the two.

\section{Baroid High Pressure-High Temperature Filter Press}

This filter press is designed to simulate down-hole conditions at elevated temperatures and pressures (under static conditions). The unit consists of a filter cell equipped with a thermometer, heating jacket with thermostat, pressure release to collect discharged filtrate, and a controlling pressure source. Mud is placed into the filter cell (with a fluid capacity of $250 \mathrm{ml}$ ) and heated to $300^{\circ} \mathrm{F}$ with an initial top pressure of $200 \mathrm{psi}$. At the appropriate temperature, the top pressure is increased to $600 \mathrm{psi}$ and the back pressure receiver is maintained at $100 \mathrm{psi}$. Filtrate is collected for 30 minutes or until blow-out. In the latter case, the time and filtrate are recorded when blow-out occurred. Filter cake thickness is measured and recorded in thirty-seconds of an inch. 
Hydrogen lon Concentration ( $\mathrm{OH}$ )

The hydrogen ion concentration $(\mathrm{pH})$ measurements of the fluids were made using a Fisher Accumet glass electrode pH meter, Model 620. Measurements of $\mathrm{pH}$ reflect the relative chemical complexity of a particular environment, and in many cases are responsible for the dissolution and/or precipitation of new mineral phases.

\section{Cation Exchange Capacity (CEC)}

Cation exchange capacity of the solid particles in the fluids was determined by the methylene blue spot test according to the procedure described by Nevins and Weintritt (1967). The CEC values were converted to surface areas in $\mathrm{m}^{2} / \mathrm{g}$ by multiplying the CEC (meq/100 $\mathrm{g}$ of clay) with 7.826 . Methylene blue molecules are adsorbed as a monolayer which lies flat on the clay surfaces. Hang and Brindley (1970) calculated the surface area of the methylene blue molecule to be $130 \AA^{2}$.

Taking the relationship between CEC and surface area into consideration, both measurements reflect the surface area of the clays exposed at the solid/water interface. These measurements reflect the dispersion of individual clay particles within the fluids. The aggregation of clay particles into a face-to-face arrangement will significantly reduce the exposed surface area and therefore the apparent CEC values. This mode of aggregation is associated with strong interlayer bonding, and is common in the presence of calcium or potassium ions. As a result, the solid/water interface is decreased, which in turn, decreases the exposed surface area of the clays and reduces fluid rheology.

\section{$X$-ray Diffraction}

$X$-ray diffraction analysis was used to determine the mineral phases in the fluids before and after autoclaving at high temperatures. Excess salts and 
hydroxides were washed off the solids by centrifugation and dialysis prior to $x$-ray diffraction and electron microscopy. Oriented clay slides were prepared and air-dried at room temperature and relative humidity of $40-50 \%$. Each slide was $\mathrm{x}$-rayed using a Philips Norelco diffractometer, which was operated at $40 \mathrm{kV}$ and $20 \mathrm{~mA}$ with Ni-filtered Cuk-alpha radiation at a scanning speed of two degrees per minute (29/2Ø). The same slides were saturated with ethylene glycol $\left(\mathrm{C}_{2} \mathrm{H}_{6} \mathrm{O}_{2}\right)$ and $x$-rayed again.

\section{Electron Microscopy}

The clay particles in the fluids are examined with a JEM $100 \mathrm{CX}$ electron microscope, which was operated at $100 \mathrm{kV}$ potential. The morphological features and chemical composition of the individual clay particles are determined using TEM images and characteristic $x$-ray spectra. These spectra are processed by a KEVEX 8000 Microanalyzer that was attached to the electron microscope column. Both electron microscopy and energy dispersive $x$-ray spectral analysis of the samples were described in our previous report SAND \#82-7037. 


\section{PROPERTIES AND RHEOLOGY OF SAPONITE}

\section{FLUID AT HIGH TEMPERATURES}

\section{Starting Material}

Saponite has recently been discovered as a possible alternative for water-based drilling fluids in the high temperature regime (Guven et al., 1985). Samples from three different saponite deposits have been selected for investigation; two of them representing large deposits in Nevada and the third from Ballarat, California. The purpose of this preliminary investigation is to determine which of these saponites exhibits the greatest potential to represent the main constituent in high temperature drilling fluids. Based on these findings, the most promising saponite will be exposed to a variety of hydrothermal conditions. A detailed description of each saponite is given as follows:

Saponite from Ballarat. California. California saponite was obtained from the Source Clay Repository of the Clay Minerals Society (University of Columbia, Missouri), and its occurrence was described by Post (1984).

The bulk sample contains about $80-85 \%$ smectite with impurities of quartz, diopside, feldspars, tremolite, and carbonates. Saponite has a basal spacing of $15.2 \AA$ in the air-dried state with sodium as the predominant interlayer cation. Upon glycolation, the basal spacing expands to $16.8 \AA$. The $x$-ray diffraction pattern displays sharp and strong basal reflections indicating a mineral with high crystallinity.

Typical saponite particles occur as compact platelets (Figures $1 \& 2$ ). These platelets display exceptionally high crystallinity and may be as large as 4.0 microns in size. $\mathrm{Mg}$ is the predominant octahedral cation and $\mathrm{Al}$ is the main tetrahedral substitution for Si as indicated by energy dispersive spectroscopy. Saponite particles also occur as thin and flexible films with large surface areas (Figure 2). As expected from this smectite, $\mathrm{Mg}$ is the predominant octahedral cation. 


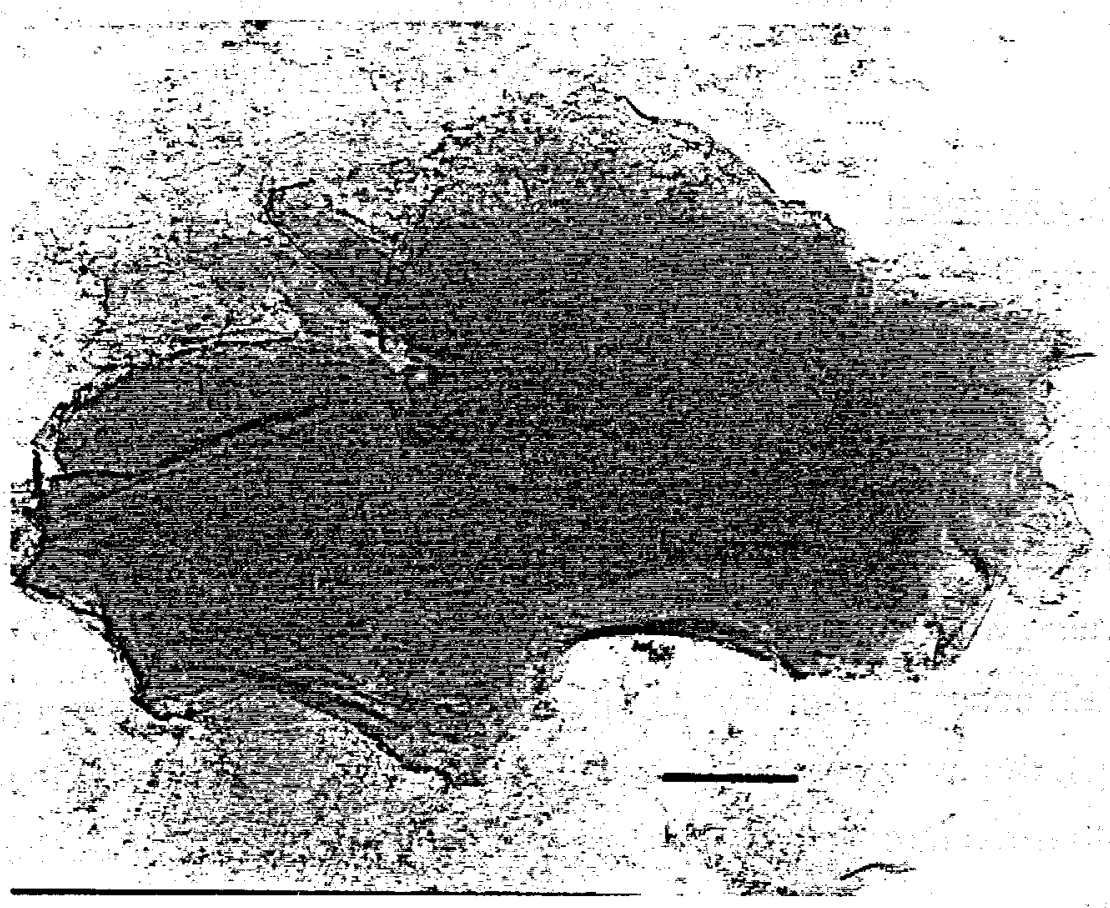

Figure 1. Typical smectite platelet demonstrating the high crystallinity of California saponite; scale: 1 micron.

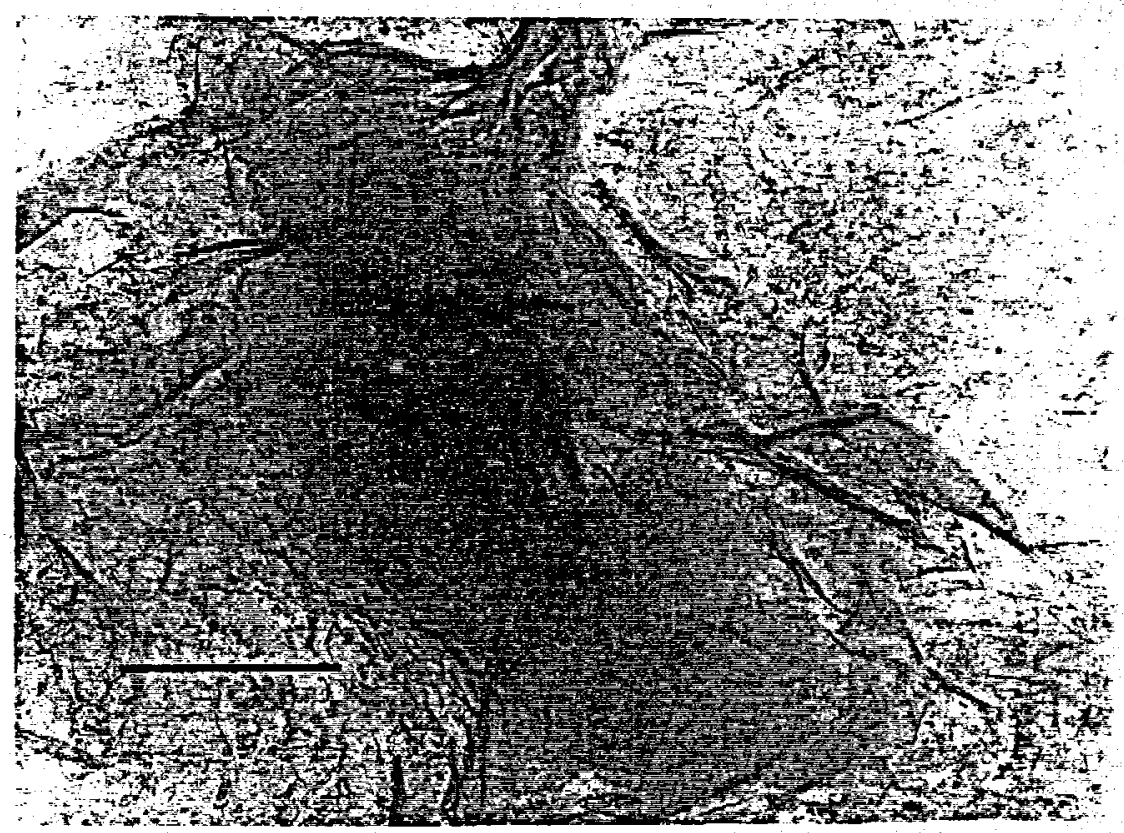

Figure 2. Thin and crumbled films of saponite exposing large surface area; scale: 0.5 micron. 
Nevada Saponite AC-53. Saponite AC-53 (Figures 3 \& 4 ) was obtained from pit AC-53 in Nevada, courtesy of Industrial Mineral Ventures, Inc.

$X$-ray diffraction analysis indicates a saponite with a broad basal reflection of 13.9 to $14.8 \AA$, which suggests a non-uniform mixture of interlayer cations. Saponite comprises about $80 \%$ of the sample. A well crystallized illite (or mica) constitutes $10-15 \%$, and minor amounts of quartz and calcite are the remaining impurities.

As seen in Figure 3, saponite occurs as subrounded flakes about 0.5 microns in size. $\mathrm{X}$-ray spectra indicate that $\mathrm{Mg}$ is the predominant octahedral cation. The Al content, however, is relatively higher than expected from saponite and is attributed to the presence of illite. Figure 4 displays a typical saponite aggregate which consists of crumbled thin films. Minute laths of illite (up to 0.5 microns) are intimately associated with these saponite aggregates. The identification of these laths as illite has been verified by the presence of high concentrations of $K$ and $A l$ in the $x$-ray spectra.

Nevada Saponite AB-9. Saponite AB-9 was also obtained from Industrial Mineral Ventures, Inc., and it is from another clay pit Nevada designated AB-9.

$X$-ray diffraction analysis indicates that the predominant clay mineral present is saponite with a basal spacing of $14.0 \AA$. Saponite makes up approximately $80 \%$ of the sample. A fine grained illite (or mica) with good crystallinity and a sharp $10 \AA$ reflection is the other major mineral component. Illite makes up about $10-15 \%$ of the sample. Carbonates and quartz are the remaining impurities found in saponite AB-9.

Electron microscopic examination shows that saponite occurs as flakes about 0.5 microns in size with irregular outlines (Figure 5 and 6). The Mg/Al ratio is approximately 3.0 , indicating that $\mathrm{Mg}$ is the main octahedral cation. High spectral intensities of $\mathrm{Al}$ and $\mathrm{K}$ confirm the existence of minute inclusions of illite rhombs and laths within the saponite flakes. 


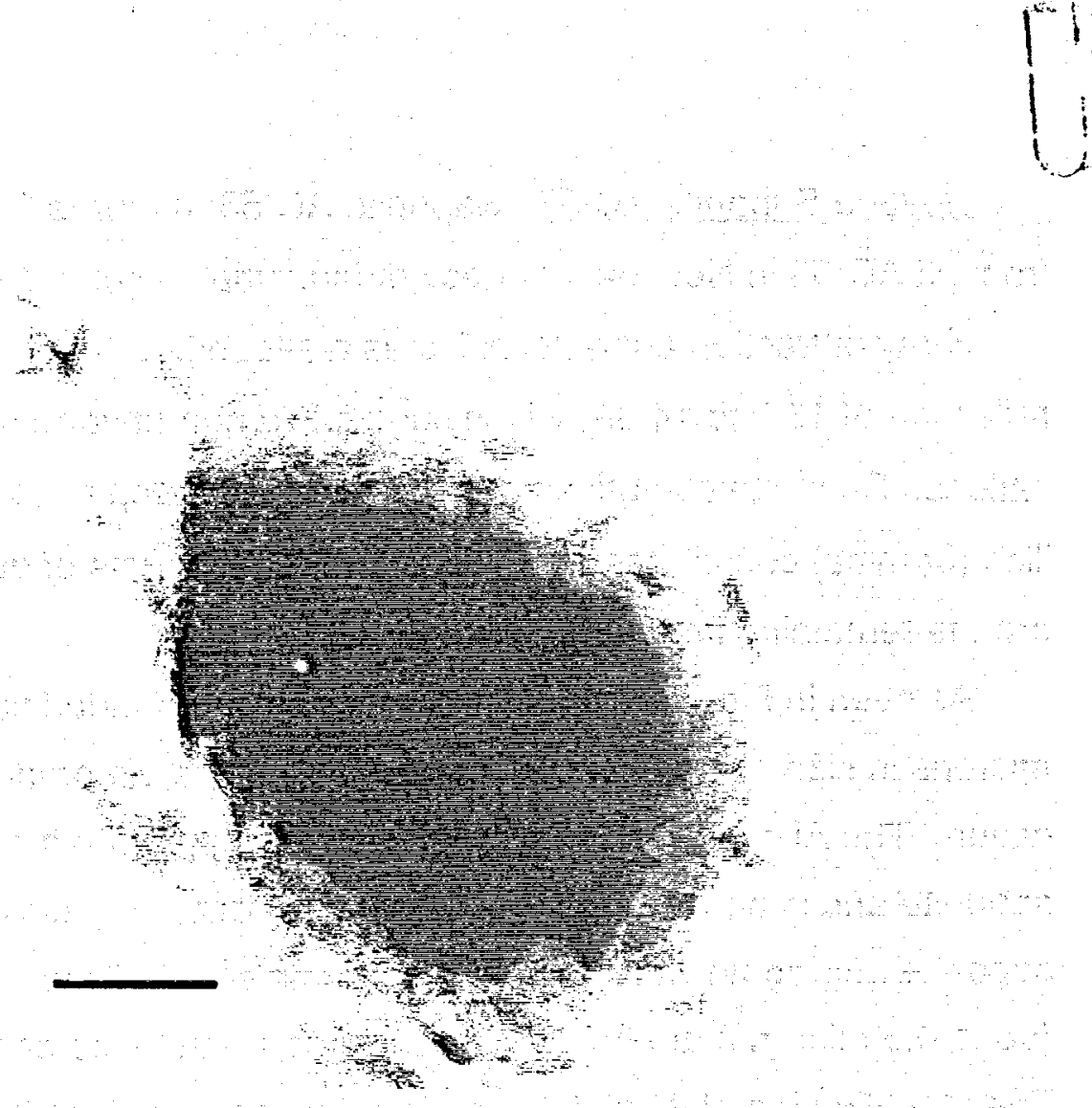

Figure 3. Typical saponite flake $(0.5$ micron) from Nevada with subrounded outlines; scale: 0.1 micron.

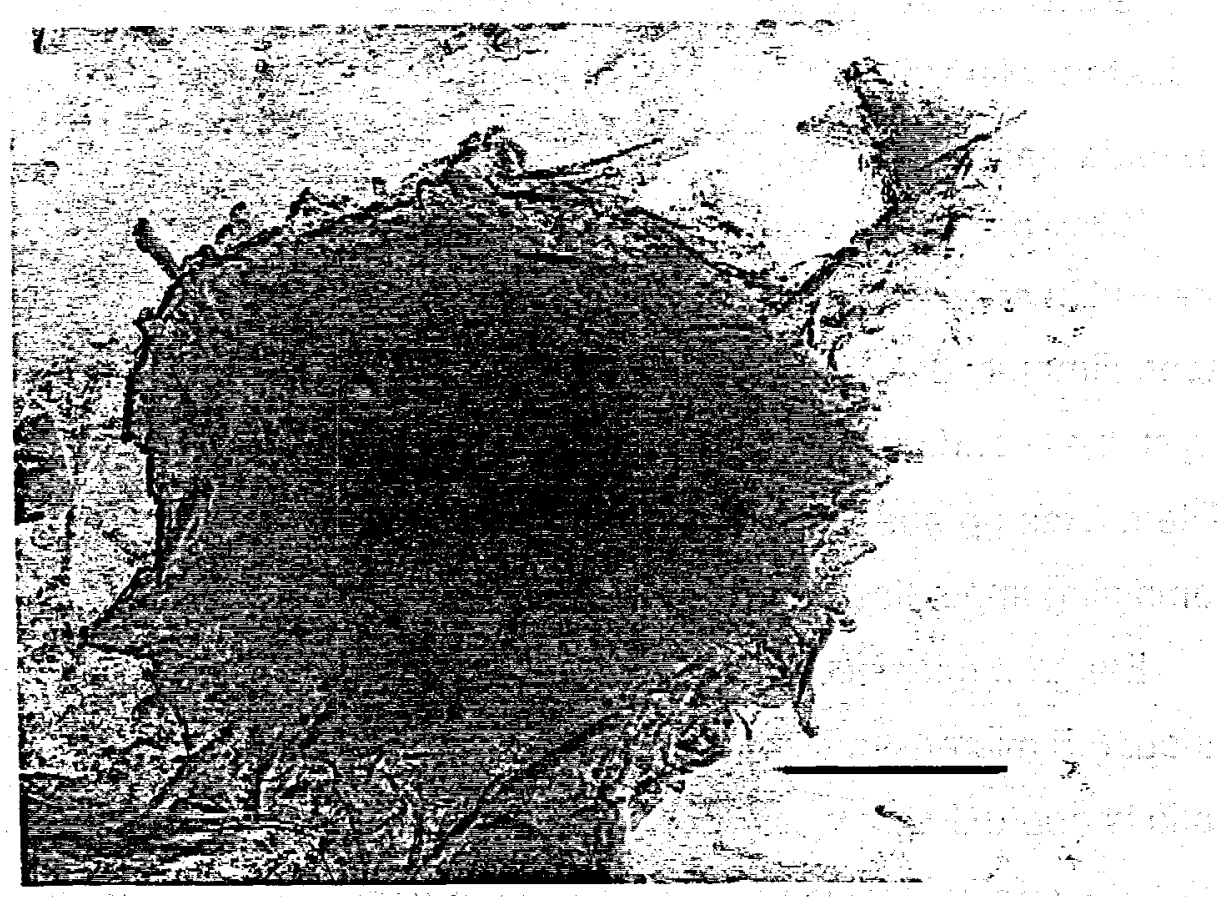

Figure 4. Saponite aggregate consisting of thin films and minute inclusions of illite laths; scale: 0.5 micron. 
.

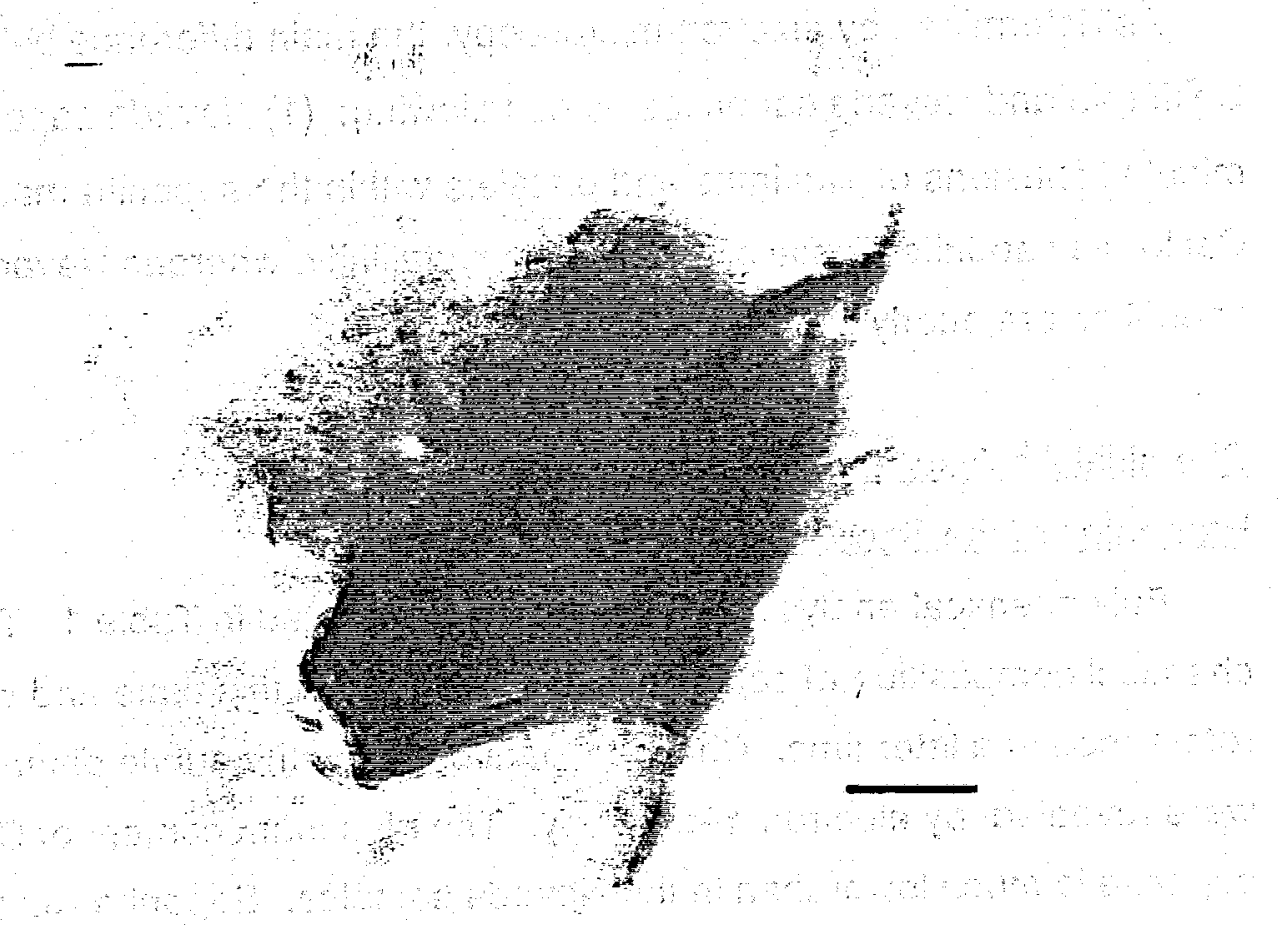

Figure 5. Minute inclusions of mica ( $0.1 \mathrm{micron})$ are intimately associated with saponite flakes; scale: 0.1 micron.

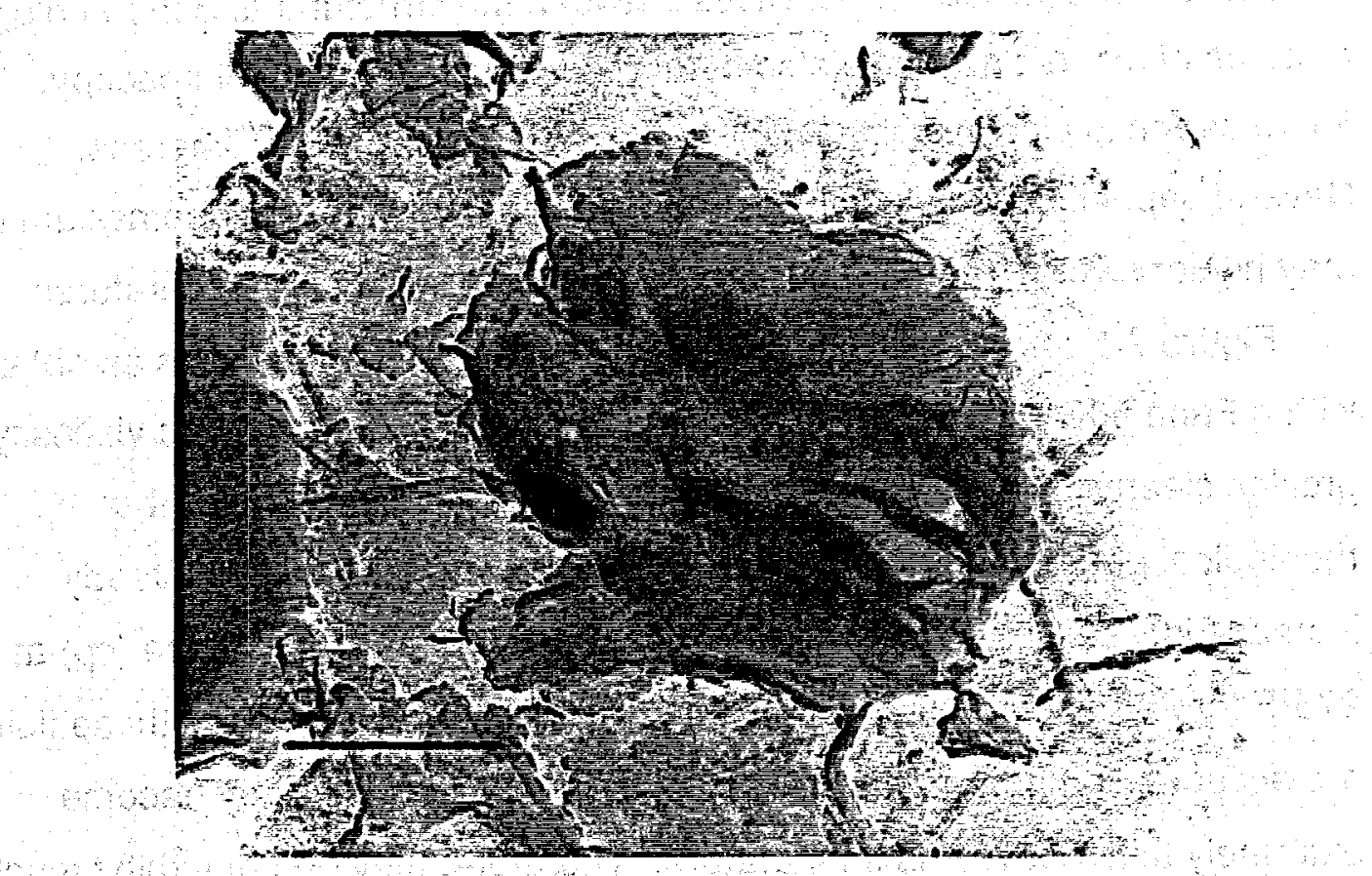

Figure 6. Saponite flake with dense inclusions of illite which display a platy morphology; scale: 0.5 micron. 
As determined by electron microscopy, the main difference between California and Nevada saponites is the following: (1) Nevada saponites have minute inclusions of illite laths and platelets within the saponite matrix, and (2) California saponite displays rather high crystallinity, whereas Nevada saponites are poorly crystalline.

\section{Chemical Analysis and Rheological}

\section{Properties of the Saponites}

Bulk chemical analysis of the saponites are listed in Table 1. The chemical composition of sepiolite is also included in this table and will be referenced at a later time. Chemical data confirms the subtle differences that were revealed by electron microscopy. The aluminum content of California saponite is much lower than in the Nevada samples. Saponite AC-53 has the highest percentage of aluminum substitution within its structure. Finally, MgO steadily decreases from $27.18 \%$ in California saponite to $23.33 \%$ in saponite AC-53. Other significant differences between the structural and morphological features of these clays have also been revealed by electron microscopy. California saponite displays higher crystallinity with larger flakes, whereas, Nevada saponites contain incipient mica inclusions with higher potassium that may hinder swelling and dispersion of clay particles at high temperatures.

Figure 7 displays the viscosity variations of the saponite fluids as obtained with a Fann $50 \mathrm{C}$ high temperature-high pressure viscometer. The viscosity profiles clearly illustrate that significant differences exist between the rheological properties of these fluids. Nevada saponites show a steady increase in viscosity above $150^{2} \mathrm{~F}$ with a maximum of 36 centipoise (cp) at $275^{\circ} \mathrm{F}$ for $\mathrm{AC}-53$, and $28 \mathrm{cp}$ at $32^{\circ} \mathrm{F}$ for $\mathrm{AB}-9$. The viscosities of these fluids are acceptable at low temperatures up to $300^{\circ} \mathrm{F}$, however, they become extremely thin above this temperature. Therefore, they do not exhibit much promise for the high temperature regime. In contrast to the Nevada saponites, California saponite shows a steady increase in viscosity with temperature and 
TABLE 1

CHEMICAL COMPOSITION OF CLAYS THAT WERE

PREVIOUSLY IGNITED (OXIDES IN WT\%)

\begin{tabular}{|c|c|c|c|c|}
\hline Oxides & $\begin{array}{l}\text { California } \\
\text { Saponite }\end{array}$ & $\begin{array}{c}\text { Nevada } \\
\text { Saponite AC-53 }\end{array}$ & $\begin{array}{c}\text { Nevada } \\
\text { Saponite AB-9 }\end{array}$ & $\begin{array}{l}\text { Nevada } \\
\text { Sepiolite }\end{array}$ \\
\hline $\mathrm{SiO}_{2}$ & 59.33 & 59.57 & 58.27 & 63.02 \\
\hline $\mathrm{Al}_{2} \mathrm{O}_{3}$ & 4.55 & 7.36 & 6.33 & 5.77 \\
\hline $\mathrm{Fe}_{2} \mathrm{O}_{3}$ & 1.20 & 2.33 & 2.43 & 1.78 \\
\hline $\mathbf{P}_{2} \mathbf{O}_{5}$ & 0.15 & 0.08 & 0.05 & 0.07 \\
\hline $\mathrm{TiO}_{2}$ & 0.67 & 0.23 & 0.23 & 0.27 \\
\hline $\mathrm{MgO}$ & 27.18 & 23.33 & 25.73 & 21.43 \\
\hline $\mathrm{CaO}$ & 5.74 & 1.87 & 2.39 & 4.43 \\
\hline $\mathrm{K}_{2} \mathrm{O}$ & 0.90 & 3.43 & 3.10 & 1.75 \\
\hline $\mathrm{Na}_{2} \mathrm{O}$ & 2.29 & 2.77 & 1.90 & 1.21 \\
\hline Total & 102.01 & 100.97 & 100.00 & 99.73 \\
\hline $\begin{array}{l}\text { Preignition } \\
\qquad\left(\mathrm{CO}_{2}\right)\end{array}$ & 0.70 & 1.74 & 2.53 & 3.67 \\
\hline
\end{tabular}


reaches a maximum of $65 \mathrm{cp}$ at $450^{\circ} \mathrm{F}$ (Figure 7).

Filtration data of the saponites are given in Table 2. Once again, California saponite appears to be far superior, as Nevada saponites display extremely high filtrate losses. The $\mathrm{pH}$ values listed in Table 2 are moderately alkaline for all fluids. Cation exchange capacities of the clays are rather similar as well.

The rheological and filtration properties of California saponite far exceed that of Nevada saponites. Therefore, California saponite exhibits the potential to be a promising constituent in high temperature drilling fluids.

\section{Pure Saponite Fluids}

The viscosity profiles of fluids containing $6 \%$ California saponite are given in Figure 8. The fluids show a steady increase in viscosity with increasing temperatures, and display an anomalous viscosity enhancement between $250-450^{\circ} \mathrm{F}$. The magnitude of this enhancement increases with subsequent levels of autoclaving. The fluid autoclaved at $600^{\circ} \mathrm{F}$ reaches a viscosity maximum of $165 \mathrm{cp}$ at $425^{\circ} \mathrm{F}$, as opposed to $81 \mathrm{cp}$ at $425^{\circ} \mathrm{F}$ for the fluid autoclaved at $300^{\circ} \mathrm{F}$ and $62 \mathrm{cp}$ at $475^{\circ} \mathrm{F}$ for the unautoclaved fluid $\left(70^{\circ} \mathrm{F}\right)$. The viscosity drops steeply from $450-500^{\circ} \mathrm{F}$ in all of the autoclaved fluids (Figure 8). Osmotic swelling of clay layers is one possible explanation for this anomalous viscosity enhancement. Another possible explanation is a variation in the mode of aggregation of individual clay particles, or possibly a combination of both.

Plastic viscosity remains rather stable at approximately $10 \mathrm{cp}$ from $70-500^{\circ} \mathrm{F}$ and increases to $21 \mathrm{cp}$ after autoclaving at $600^{\circ} \mathrm{F}$. Yield point and gel strength exhibit a proportional decrease from $70-500^{\circ} \mathrm{F}$, however, they increase abruptly at $600^{\circ} \mathrm{F}$ (Table 3 ). Fluid loss and filter cake thickness values of the saponite fluids are extremely good at all temperatures. The API filtrate loss remains stable at $8 \mathrm{ml} / 30 \mathrm{~min}$ for all fluids. The HP-HT filtration loss drops from $36 \mathrm{ml} / 30 \mathrm{~min}$ for the unautoclaved fluid to $24 \mathrm{ml} / 30 \mathrm{~min}$ after 


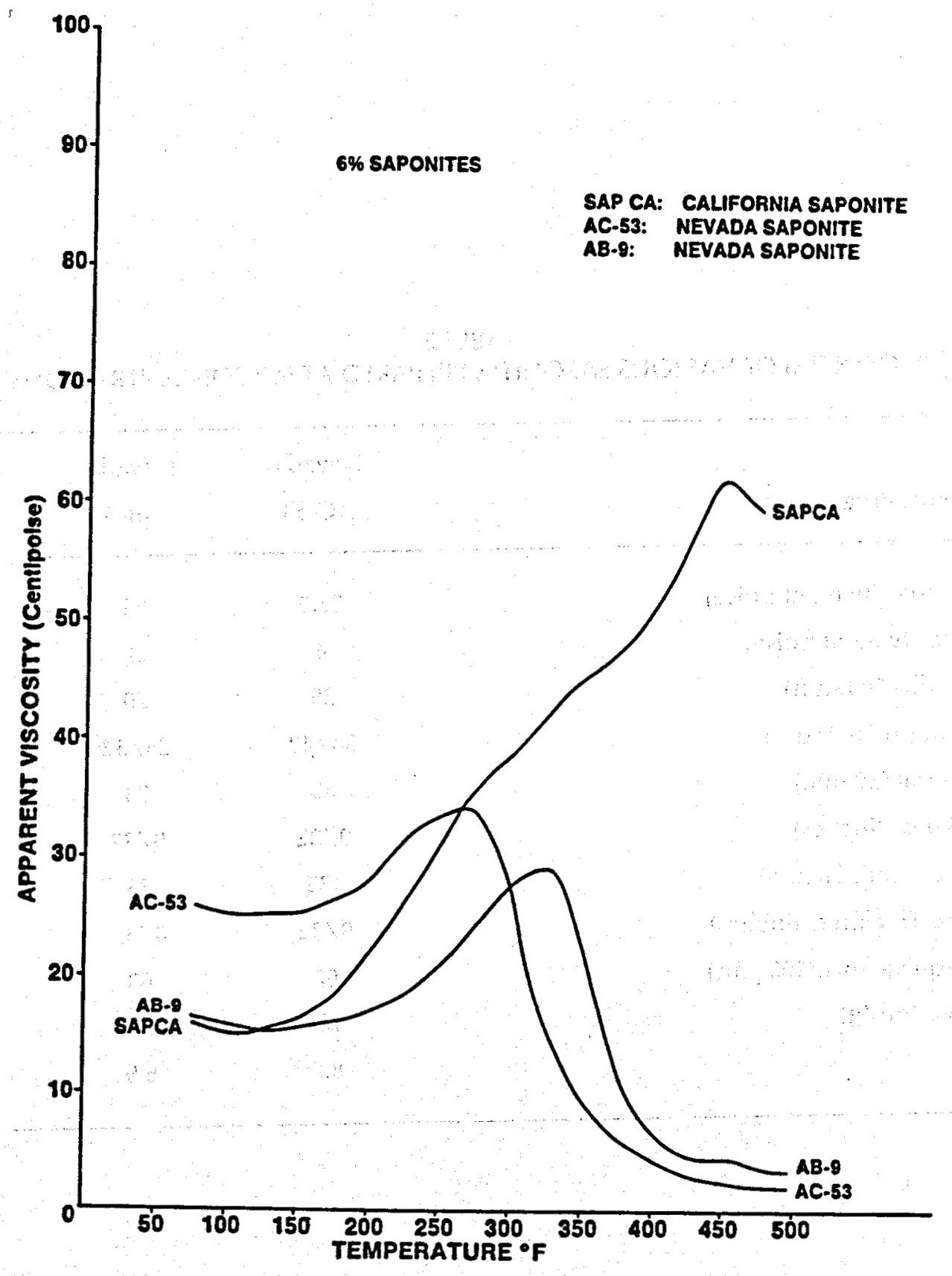

Figure 7. Viscosity profiles of various saponite fluids prepared at $6 \%$ concentrations. 
TABLE 2

PROPERTIES OF VARIOUS SAPONITES PREPARED AT 6\% CONCENTRATIONS

\begin{tabular}{lccc}
\hline \multicolumn{1}{c}{ Fluid Properties } & Nevada & Nevada & California \\
& AC-53 & AB-9 & \\
\hline Apparent Viscosity (centipoise) & 23.5 & 13 & 18 \\
Plastic Viscosity (centipoise) & 4 & 3 & 7 \\
Yield Point (lb/100 sq ft) & 39 & 20 & 22 \\
Gei Strength (lb/100 sq ft) & $34 / 42$ & $24 / 32$ & $22 / 28$ \\
API Filtrate (ml/30 min) & 80 & 94 & 8 \\
Cake Thickness (inches) & $9 / 32$ & $9 / 32$ & $1 / 32$ \\
HP-HT Filtrate (ml/30 min) & 135 & 86 & 36 \\
HP-HT Cake Thickness (inches) & $9 / 32$ & $8 / 32$ & $3 / 32$ \\
CEC (milliequivalents/100 gms) & 67 & 63 & 72 \\
Surface Area (m ${ }^{2} / g$ ) & 524 & 493 & 563 \\
pH & 8.7 & 8.9 & 8.6 \\
\hline
\end{tabular}




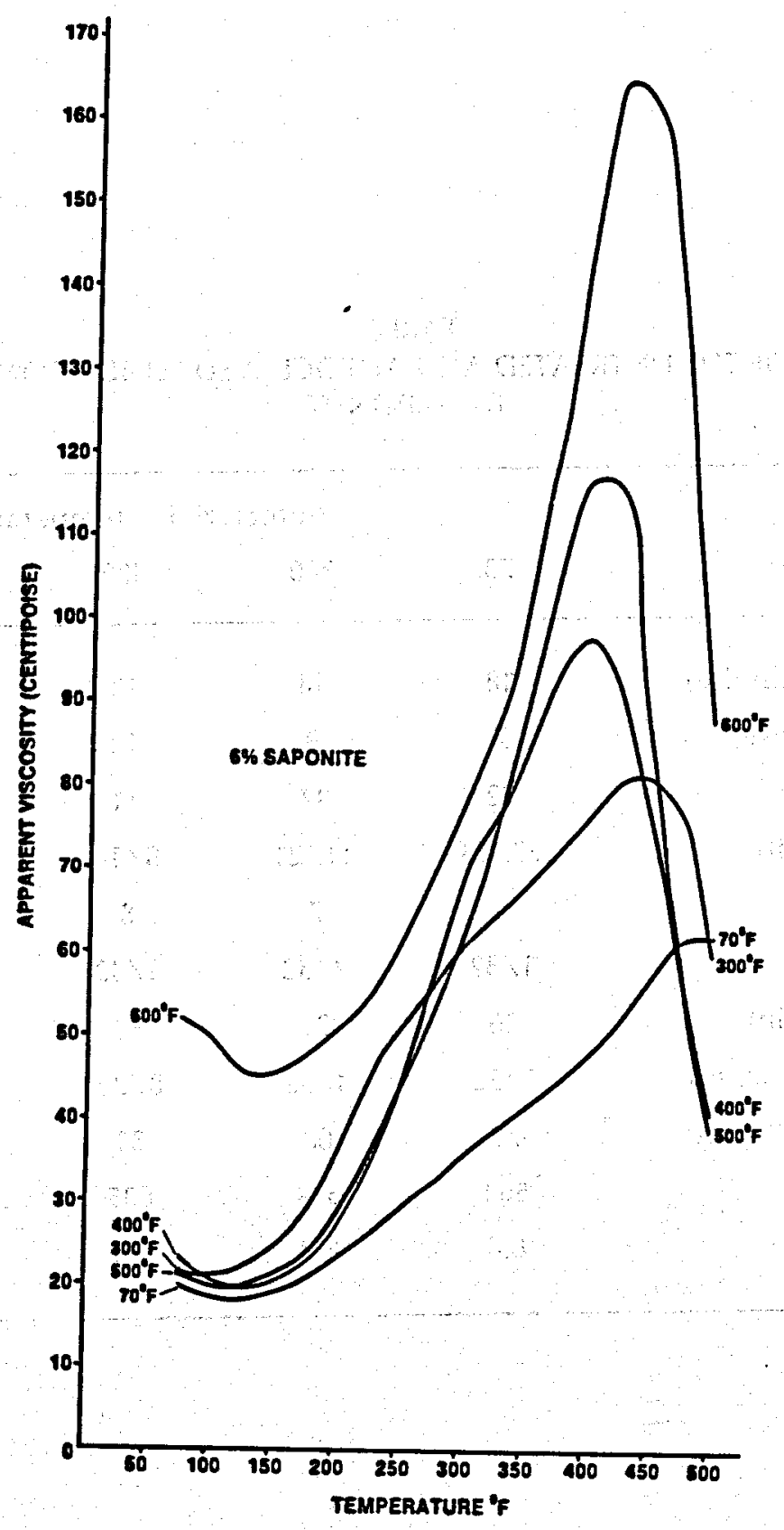

Figure 8. Viscosity profiles of $6 \%$ saponite fluids autoclaved at various temperatures. 
TABLE 3

PROPERTIES OF THE UNTREATED AND AUTOCLAVED FLUIDS CONSISTING OF

$6 \%$ SAPONITE

\begin{tabular}{lccccc}
\hline \multicolumn{1}{c}{ fluid Properties } & \multicolumn{5}{c}{ Autoclaved at temperatures ( ${ }^{\circ} \mathrm{F}$ ) } \\
& 70 & 300 & 400 & 500 & 600 \\
\hline & & & & \\
Apparent Viscosity (centipoise) & 18 & 18 & 18 & 15 & 46 \\
Plastic Viscosity (centipoise) & 7 & 9 & 12 & 11 & 27 \\
Yield Point (lb/100 sq ft) & 22 & 17 & 11 & 8 & 49 \\
Gel Strength (lb/100 sq ft) & $22 / 28$ & $11 / 21$ & $6 / 14$ & $2 / 11$ & $15 / 28$ \\
API Filtrate (ml/30 min) & 8 & 7 & 8 & 9 & 8 \\
Cake Thickness (inches) & $1 / 32$ & $2 / 32$ & $2 / 32$ & $2 / 32$ & $2 / 32$ \\
HP-HT Filtrate (ml/30 min) & 36 & 22 & 38 & 20 & 24 \\
HP-HT Cake Thickness (inches) & $3 / 32$ & $4 / 32$ & $8 / 32$ & $7 / 32$ & $7 / 32$ \\
CEC (milliequivalents/100 gms) & 72 & 68 & 81 & 78 & 76 \\
Surface Area (m ${ }^{2} / \mathrm{g}$ ) & 564 & 534 & 635 & 607 & 591 \\
pH & 8.6 & 8.3 & 8.3 & 8.6 & 8.5 \\
& & & & & \\
\hline
\end{tabular}


autoclaving at $600^{\circ} \mathrm{F}$. This is amazingly different from the bentonite fluids. The CEC and $\mathrm{pH}$ values remain remarkably stable indicating that saponite has the potential of making an extremely good high temperature drilling fluid.

Preliminary $x$-ray diffraction analysis indicates that saponite has a basal spacing of $15.2 \AA$ in the air-dried state and fully expands to $17.0 \AA$ upon glycolation. Saponite retains strong and sharp basal reflections even in fluid autoclaved at $600^{\circ} \mathrm{F}$, indicating that saponite remains stable at high temperatures.

The dissolution of impurities such as carbonates seems to provide free $\mathrm{Ca}^{2+}$ and $\mathrm{Mg}^{2+}$ in solution. These ions are incorporated into the interlayer structure of saponite and give rise to the formation of two distinct peaks at $\mathbf{1 5 . 0}$ and $12.7 \AA$ in the fluid autoclaved at $600^{\circ} \mathrm{F}$. There appears to be a heterogenous mixture of water-cation complexes. A minor reflection at $33.2 \AA$ indicates the presence of $\mathrm{Ca}-, \mathrm{Mg}$ - and/or $\mathrm{Na}$-smectite mixed-layers. High temperatures seem to promote the preferred orientation of these layer silicates.

\section{Sapenite/KOH Fluids}

The viscosity profiles of $6 \%$ saponite $/ 1 \% \mathrm{KOH}$ are rather thin at all temperatures (Figure 9). Only the fluid autoclaved at $400^{\circ} \mathrm{F}$ shows no appreciable viscosity enhancement. However, it also remains below $10 \mathrm{cp}$ as measured with the Fann $50 \mathrm{C}$. Other rheological properties are given in Table 4. The fluids autoclaved at 300,500 , and $600^{\circ} \mathrm{F}$ show extremely low yield points and gel strengths. The filtration control of saponite is rather poor in the presence of $\mathrm{KOH}$. The most significant increase exists in the fluids autoclaved at and above $500^{\circ} \mathrm{F}$. The presence of the K-ion seems to promote a face-to-face association of clay particles, which leads to a decrease in CEC. The $\mathrm{pH}$ remains highly alkaline at all temperatures (12.5 to 12.8).

Saponite remains stable with a basal spacing of $12.3 \AA$ up to and including the fluid autoclaved at $500^{\circ} \mathrm{F}$, which is considerably different than 


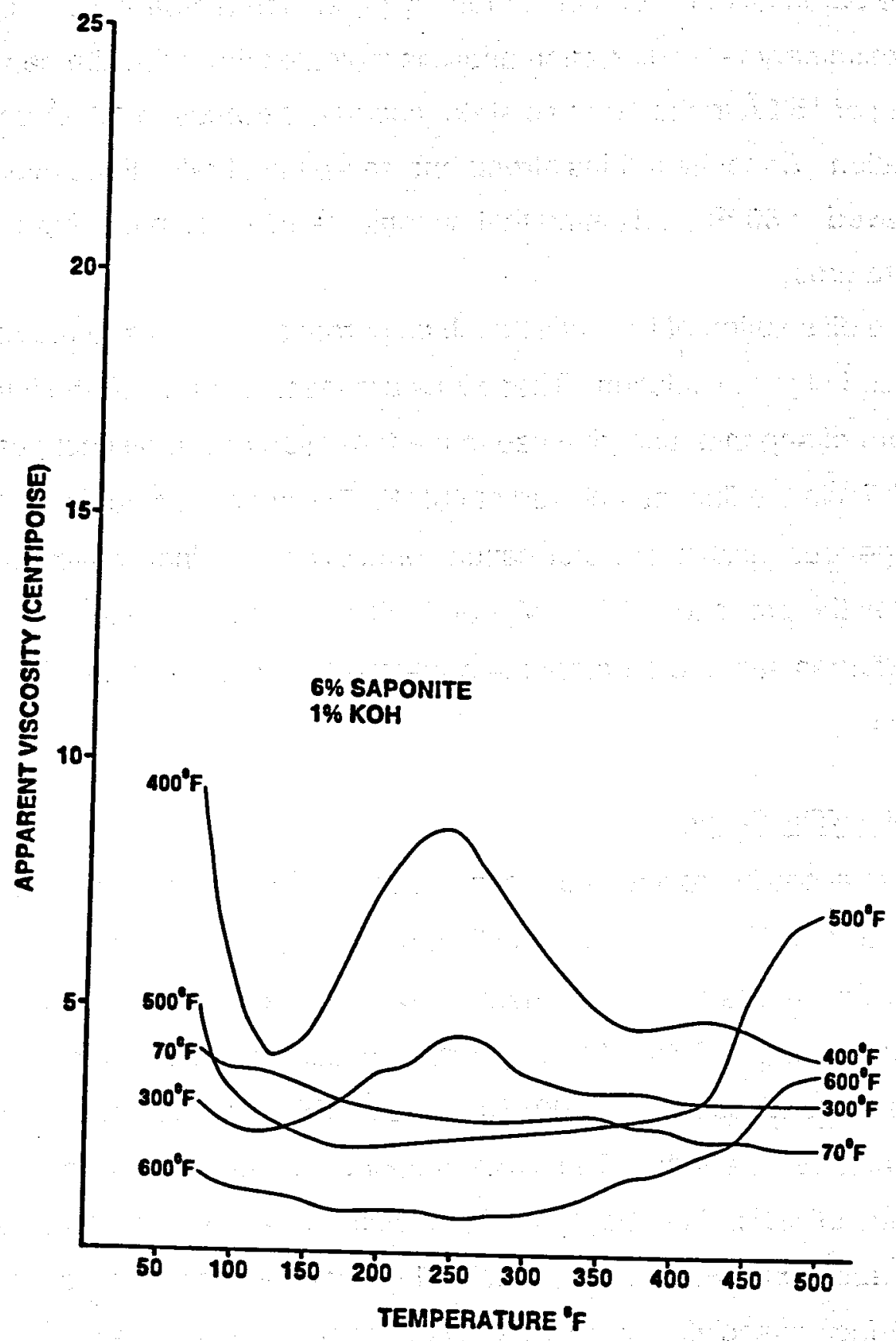

Figure 9. Viscosity profiles of $6 \%$ saponite $/ 1 \% \mathrm{KOH}$ fluids autoclaved at various temperatures. 
TABLE 4

PROPERTIES OF THE UNTREATED AND AUTOCLAVED FLUIDS CONSISTING OF $6 \%$ SAPONITE $/ 1 \% \mathrm{KOH}$

\begin{tabular}{|c|c|c|c|c|c|}
\hline \multirow[b]{2}{*}{ Fluid Properties } & \multicolumn{5}{|c|}{ Autoclaved at temperatures $\left({ }^{\circ} \mathrm{F}\right)$} \\
\hline & 70 & 300 & 400 & 500 & 600 \\
\hline Apparent Viscosity (centipoise) & 5 & 3 & 9 & 4 & 3 \\
\hline Plastic Viscosity (centipoise) & 3 & 2 & 3 & 4 & 3 \\
\hline Yield Point (lb/100 sq ft) & 3 & 1 & 11 & 0 & $\mathbf{0}$ \\
\hline Gel Strength (lb/100 sq ft) & $3 / 4$ & $1 / 3$ & $6 / 8$ & $.5 / .5$ & $.5 / .5$ \\
\hline API Filtrate $(\mathrm{ml} / 30 \mathrm{~min})$ & 36 & 37 & 39 & 90 & 168 \\
\hline Cake Thickness (inches) & $2 / 32$ & $2 / 32$ & $3 / 32$ & $4 / 32$ & $5 / 32$ \\
\hline HP-HT Filtrate $(\mathrm{ml} / 30 \mathrm{~min})^{*}$ & 216 & 172 & 114 & 228 & $256 / 11$ \\
\hline HP-HT Cake Thickness (inches) & $4 / 32$ & $6 / 32$ & $6 / 32$ & $9 / 32$ & $\cdots$ \\
\hline CEC (milliequivalents $/ 100 \mathrm{gms}$ ) & 65 & 71 & $\pi$ & 63 & 25 \\
\hline Surface Area $\left(m^{2} / g\right)$ & 509 & 556 & 603 & 493 & 196 \\
\hline $\mathrm{pH}$ & 12.8 & 12.8 & 12.8 & 12.6 & 12.5 \\
\hline
\end{tabular}

*The amount of filtrate and time (in minutes) until blowout is noted, respectively. 
with bentonite/KOH fluids. The basal spacing expands to $16.5 \AA$ upon glycolation. Saponite begins to break-down in the fluid autoclaved at $600^{\circ} \mathrm{F}$. The intensity of the primary basal reflection has been reduced considerably. This basal spacing ranges from 12.2 to $10.9 \AA$. The latter of which suggests the partial dehydration of the interlayer structure. There are no major mineral reactions in these fluids, except the formation of tremolite in small amounts at $600^{\circ} \mathrm{F}$.

\section{Saponite $\mathrm{Na}_{2} \mathrm{CO}_{3}$ Fluids}

The addition of $\mathrm{Na}_{2} \mathrm{CO}_{3}$ has significantly reduced the anomalous viscosity enhancement present in the pure saponite system (Figure 10). In fact, the viscosity remains between 3 and $13.5 \mathrm{cp}$ at all temperatures. Other fluid properties are given in Table 5. The API fluid loss is rather stable up to $400^{\circ} \mathrm{F}$ and ranges between 12 and $26 \mathrm{ml} / 30 \mathrm{~min}$; however, it shows a dramatic increase to 54 and $100 \mathrm{ml} / 30 \mathrm{~min}$ at 500 and $600^{\circ} \mathrm{F}$, respectively. Similarly, HP-HT fluid loss increases at 500 and $600^{\circ} \mathrm{F}$. CEC displays a pattern similar to fluid loss as it shows a considerable drop at and above $500^{2} \mathrm{~F}$. This seems to imply that the presence of $\mathrm{Na}_{2} \mathrm{CO}_{3}$ has affected the mode of aggregation of individual clay particles at high temperatures, which has decreased surface area, and consequently, decreased fluid properties.

$X$-ray diffraction indicates that saponite remains stable at high temperatures and does not undergo any major mineral reactions. Contrary to the high temperature mineral reactions of bentonite $/ \mathrm{Na}_{2} \mathrm{CO}_{3}$ fluids. The basal spacing remains stable at $12.2 \AA$ up to and including $500^{\circ} \mathrm{F}$, indicating one molecular layer of water. At $600^{\circ} \mathrm{F}$, however, the basal spacing ranges from 12.4 to $14.3 \AA$, which suggests a heterogenous mixture of one and two molecular layers of water. In addition, small amounts of tremolite also form at $600^{\circ} \mathrm{F}$. 


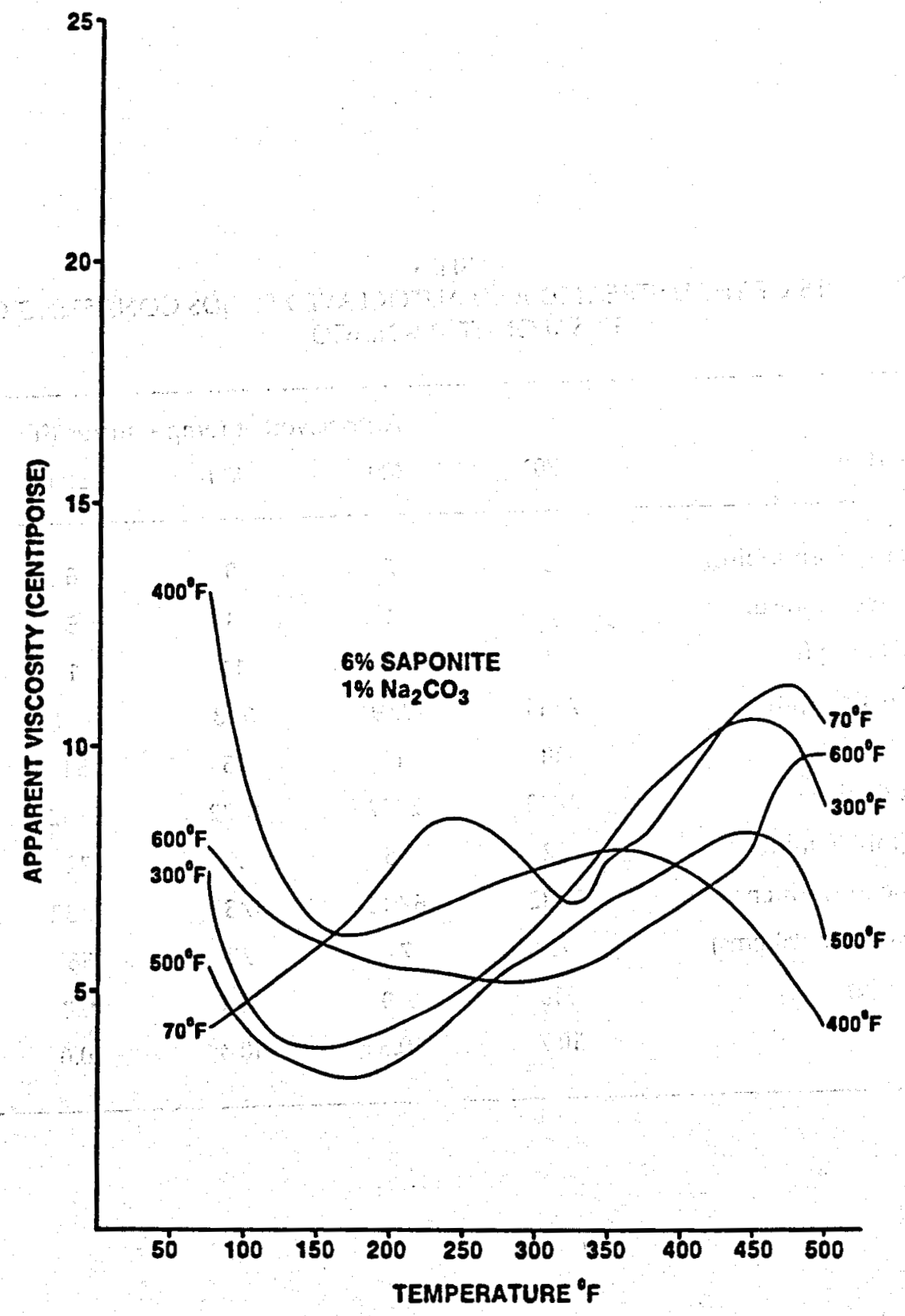

Figure 10 . Viscosity profiles of $6 \%$ saponite $/ 1 \% \mathrm{Na}_{2} \mathrm{CO}_{3}$ fluids autoclaved at various temperatures. 
TABLE 5

PROPERTIES OF THE UNTREATED AND AUTOCLAVED FLUIDS CONSISTING OF $6 \%$ SAPONITE $/ 1 \% \mathrm{Na}_{2} \mathrm{CO}_{3}$

\begin{tabular}{|c|c|c|c|c|c|}
\hline \multirow[b]{2}{*}{ Fluid Properties } & \multicolumn{5}{|c|}{ Autoclaved at temperatures $\left({ }^{\circ} \mathrm{F}\right)$} \\
\hline & 70 & 300 & 400 & 500 & 600 \\
\hline Apparent Viscosity (centipoise) & 5 & 7 & 9 & 6 & 7 \\
\hline Plastic Viscosity (centipoise) & 3 & 4 & 3 & 5 & 6 \\
\hline Yield Point ( $\mathrm{lb} / 100 \mathrm{sq} \mathrm{ft})$ & 3 & 5 & 11 & 1 & 2 \\
\hline Gel Strength (lb/100 sq ft) & $7 / 11$ & $3 / 9$ & $6 / 8$ & $1 / 1$ & $1 / 2$ \\
\hline API Filtrate (ml/30 min) & 18 & 17 & 26 & 54 & 100 \\
\hline Cake Thickness (inches) & $2 / 32$ & $2 / 32$ & $4 / 32$ & $6 / 32$ & $8 / 32$ \\
\hline HP-HT Filtrate $(\mathrm{ml} / 30 \mathrm{~min})$ & 62 & 58 & 66 & 72 & 130 \\
\hline HP-HT Cake Thickness (inches) & $6 / 32$ & $6 / 32$ & $8 / 32$ & $7 / 32$ & $8 / 32$ \\
\hline CEC (milliequivalents/100 gms) & 79 & 74 & 72 & 56 & 36 \\
\hline Surface Area $\left(\mathrm{m}^{2} / \mathrm{g}\right)$ & 618 & 579 & 563 & 438 & 282 \\
\hline $\mathrm{pH}$ & 10.7 & 10.5 & 10.4 & 10.0 & 10.0 \\
\hline
\end{tabular}




\section{Saponite/High Molecular Weight Polymer Fluids}

Rheological properties of this fluid system are summarized in Figure 11 and Table 6. The addition of $1 \%$ high molecular weight polymer completely leliminates the anomalous viscosity enhancement of pure saponite fluids. Subsequent levels of autoclaving decrease the initial viscosity of this fluid system up to and including the fluid autoclaved at $400^{\circ} \mathrm{F}$. The fluid autoclaved at $500^{\circ} \mathrm{F}$, however, exhibits a slight increase in rheological properties as seen in Figure 11 and Table 6. The filtration control of these fluids is extremely good at all temperatures. The CEC and $\mathrm{pH}$ values indicate that the polymer begins to break-down above $400^{\circ} \mathrm{F}$.

$X$-ray diffraction analysis indicates a smectite with a basal spacing that ranges from 14.5 to $12.5 \AA$ before autoclaving. After autoclaving at 300 and $400^{\circ} \mathrm{F}$, the basal spacing range contracts to a $12.5 \AA$ peak. Finally, at $500^{\circ} \mathrm{F}$ the basal spacing expands to $14.8 \AA$. This variation in basal spacing suggests that saponite has different hydration states in the presence of high molecular weight polymer. There are no mineral reactions present in these fluids.

Saponite/Low Molecular Weight Polymer Fluids

The addition of $1 \%$ low molecular weight polymer has rather favorable affects upon the fluid properties of saponite. Similar to the high molecular weight polymer system, low molecular weight polymer completely eliminates the viscosity enhancement at elevated temperatures (Figure 12). Therefore, it is used primarily as a thinning or deflocculating agent. Other fluid properties are listed in Table 7. The API and HP-HT fluid losses have been improved slightly as compared to the pure saponite system. The fluid pH remains moderately alkaline and ranges from 8.8 to 8.3 at 70 and $400^{\circ} \mathrm{F}$, respectively.

The basal spacing remains stable at $12.4 \AA$ and expands to $16.8 \AA$ upon glycolation. There are no mineral reactions present in this system. 


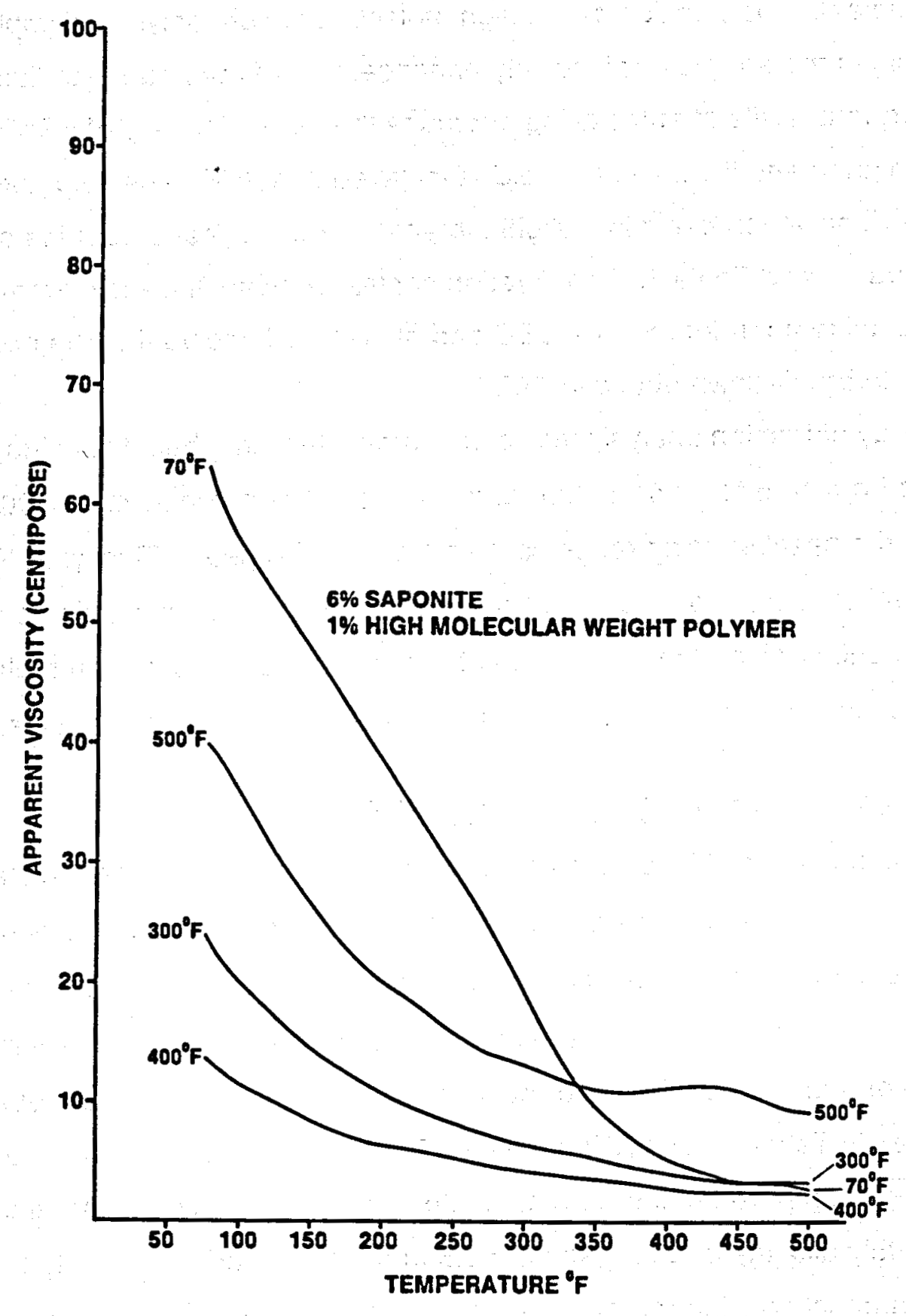

Figure 11. Viscosity profiles of $6 \%$ saponite $/ 1 \%$ high molecular weight polymer fluids autoclaved at various temperatures. 
TABLE 6

PROPERTIES OF THE UNTREATED AND AUTOCLAVED FLUIDS CONSISTING OF $6 \%$ SAPONITE $/ 1 \%$ HIGH MOLECULAR WEIGHT POLYMER

\begin{tabular}{lccccc}
\hline \multicolumn{1}{c}{ Fluid Properties } & \multicolumn{5}{c}{ Autoclaved at temperatures ( ${ }^{\circ \mathrm{F}}$ ) } \\
& 70 & 300 & 400 & 500 \\
\hline Apparent Viscosity (centipoise) & 62 & 26 & 18 & 47 \\
Plastic Viscosity (centipoise) & 42 & 20 & 14 & 28 \\
Yield Point (lb/100 sq ft) & 39 & 11 & 7 & 38 \\
Gel Strength (lb/100 sq ft) & $8 / 14$ & $5 / 6$ & $5 / 5$ & $6 / 9$ \\
API Filtrate (ml/30 min) & 4 & 3 & 3 & 4 \\
Cake Thickness (inches) & $1 / 32$ & $1 / 32$ & $1 / 32$ & $1 / 32$ \\
HP-HT Filtrate (ml/30 min) & 18 & 18 & 26 & 18 \\
HP-HT Cake Thickness (inches) & $2 / 32$ & $2 / 32$ & $2 / 32$ & $2 / 32$ \\
CEC (milliequivalents/100 gms) & 99 & 97 & 99 & 72 \\
Surface Area (m ${ }^{2} / \mathrm{g}$ ) & 775 & 759 & 775 & 571 \\
pH & 7.7 & 8.7 & 8.8 & 9.1 \\
\hline
\end{tabular}




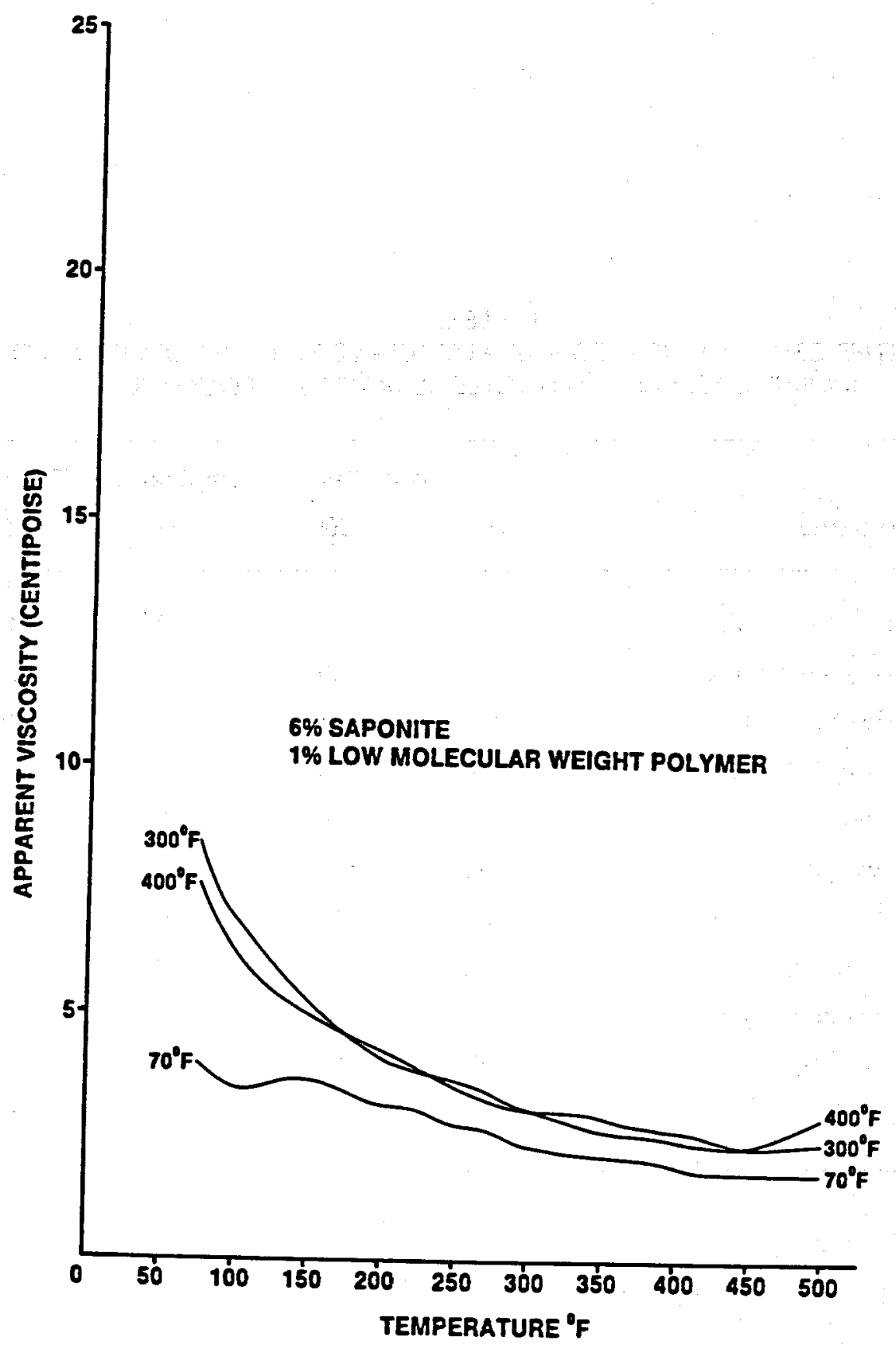

Figure 12. Viscosity profiles of $6 \%$ saponite $/ 1 \%$ low molecular weight polymer fluids autoclaved at various temperatures. 
TABLE 7:

PROPERTIES OF THE UNTREATED AND AUTOCLAVED FLUIDS CONSISTING OF 6\% SAPONITE/1\% LOW MOLECULAR WEIGHT POLYMER

\begin{tabular}{|c|c|c|c|}
\hline \multirow[b]{2}{*}{ Fluid Properties } & \multicolumn{3}{|c|}{ Autoclaved at temperatures $\left({ }^{\circ} \mathrm{F}\right)$} \\
\hline & 70 & 300 & 400 \\
\hline Apparent Viscosity (centipoise) & 6 & 10 & 10 \\
\hline Plastic Viscosity (centipoise) & 5 & 8 & 9 \\
\hline Yield Point (lb/100 sq ft) & 1 & 2 & 2 \\
\hline Gel Strength (lb/100 sq ft) & $1 / 1$ & $2 / 3$ & $1 / 2$ \\
\hline API Filtrate $(\mathrm{ml} / 30 \mathrm{~min})$ & 6 & 4 & 4 \\
\hline Cake Thickness (inches) & $1 / 32$ & $1 / 32$ & $1 / 32$ \\
\hline HP-HT filtrate $(\mathrm{ml} / 30 \mathrm{~min})$ & 30 & 24 & 28 \\
\hline HP-HT Cake Thickness (inches) & $2 / 32$ & $2 / 32$ & $2 / 32$ \\
\hline CEC (milliequivalents / 100 gms) & 79 & 79 & 75 \\
\hline Surface Area $\left(\mathrm{m}^{2} / \mathrm{g}\right)$ & 618 & 618 & 587 \\
\hline pH & 8.8 & 8.4 & 8.3 \\
\hline
\end{tabular}




\section{PROPERTIES AND RHEOLOGY OF SAPONITE - SEPIOLITE FLUIDS AT HIGH TEMPERATURES}

\section{Starting Material}

Sepiolite that was used in this investigation is from the Aschenbrenner deposit, Nye County, Nevada. It was provided by Industrial Mineral Ventures Company, Golden, Colorado.

The bulk chemical analysis of sepiolite is given in Table 1. Preliminary $x$-ray diffraction analysis indicates that sepiolite has a basal spacing of $12.1 \AA$. Sepiolite particles occur either as individual fibers up to 2.0 microns in length and 200-300 $\AA$ in width, or as birdnest-type aggregates of fibers as revealed by electron microscopy (Figure 13a). Quartz, feldspar, carbonates and illite are the common impurities found in the bulk sample.

Saponite used in this study is from Ballarat, California. A thorough account of its mineralogy has already been given.

A 1:1 ratio of saponite-sepiolite based drilling fluids has been autoclaved at temperatures from 300 to $600^{\circ} \mathrm{F}$ with the respective additives, and by procedures already discussed. A systematic examination of the rheology and changes in mineral components are described in the following.

\section{Saponite - Sepiolite Fluids}

The viscosity profiles of $6 \%$ saponite-sepiolite fluids before and after autoclaving are given in Figure 13b. The unautoclaved fluid has a viscosity profile somewhat different from that of pure saponite. This fluid has an initial viscosity of $30.5 \mathrm{cp}$ at $75^{\circ} \mathrm{F}$ compared to $19.9 \mathrm{cp}$ for the pure saponite fluid at $75^{\circ} \mathrm{F}$. Furthermore, saponitesepiolite displays two distinct but minor viscosity enhancements; at $225^{\circ} \mathrm{F}$ and $375^{\circ} \mathrm{F}$ with a corresponding viscosity of $41.9 \mathrm{cp}$ and $43.3 \mathrm{cp}$, respectively. After autoclaving saponite-sepiolite to $300^{9} \mathrm{~F}$, its viscosity profile is significantly different than pure saponite at the same temperature. This fluid has a broad viscosity 


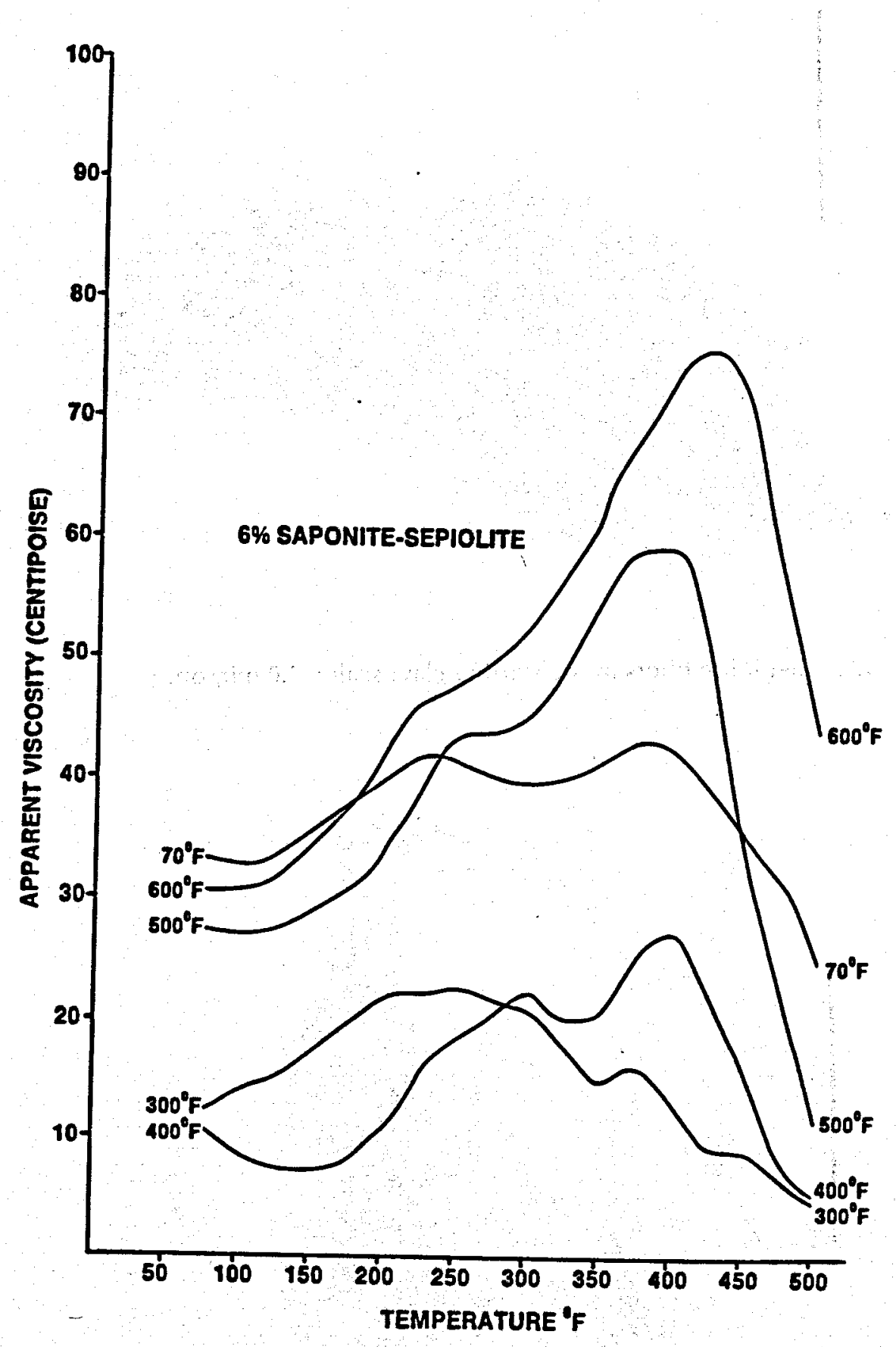

Figure 13b. Viscosity profiles of $6 \%$ saponite-sepiolite fluids autoclaved at various temperatures. 


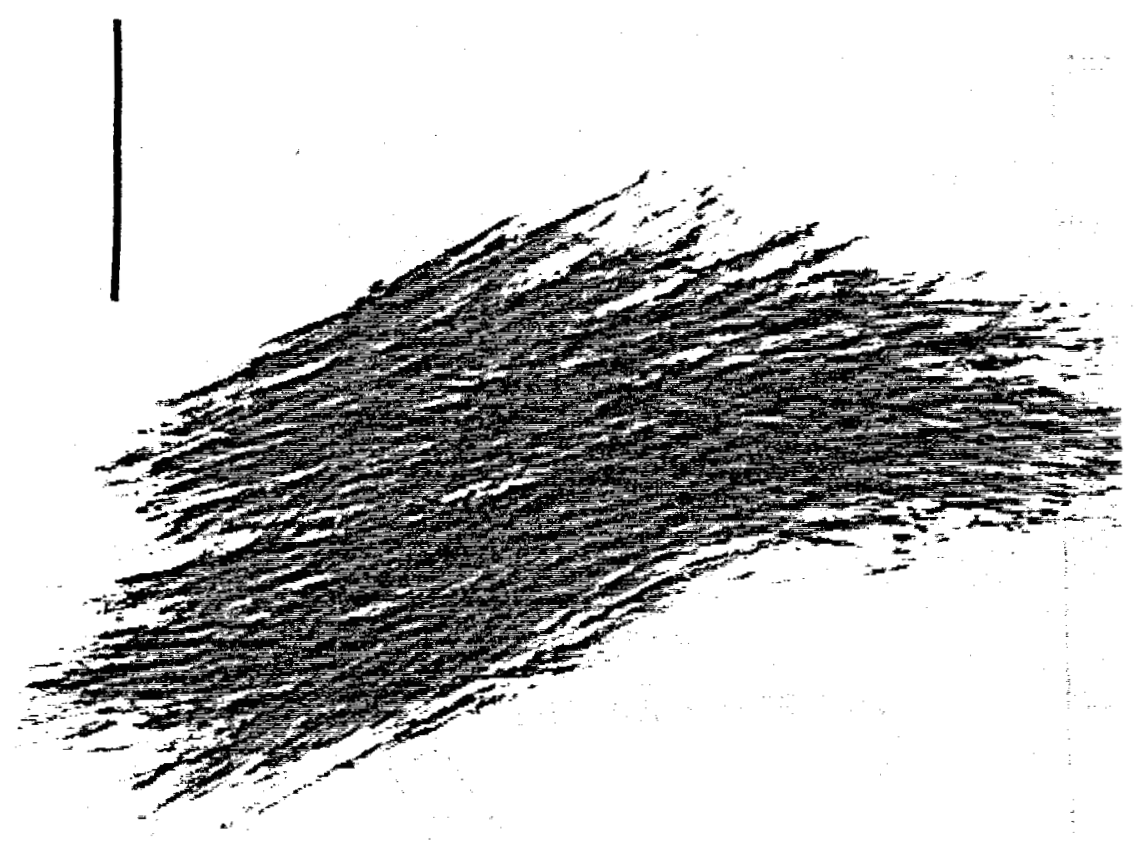

Figure 13a. Sepiolite fibers in the starting clay; scale: 1.0 micron.

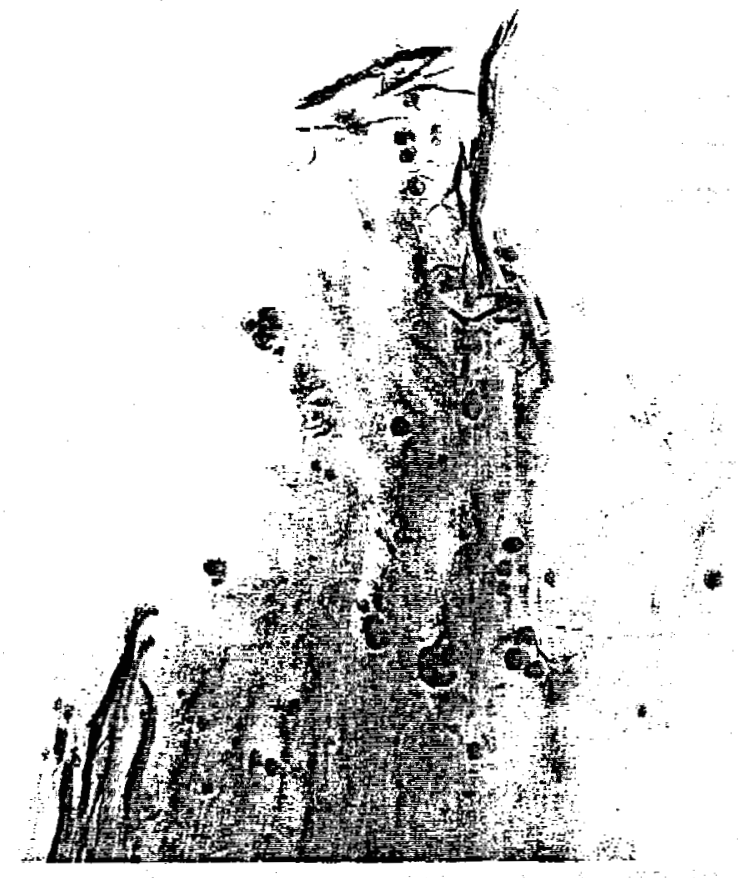

Figure 13c. Smectite (stevensite variety) formed from the sepiolite in the sepiolite fluid at $400^{\circ} \mathrm{F}$; scale: 1.0 micron. 
enhancement which reaches a maximum of $22.5 \mathrm{cp}$ at $250^{\circ} \mathrm{F}$. The fluid autoclaved at $400^{\circ} \mathrm{F}$ begins to illustrate a characteristic saponite profile, but on a much reduced scale. It is apparent in the fluids autoclaved at 500 and $600^{\circ} \mathrm{F}$ that smectite is the main clay component, as the viscosity profiles are analogous to that of pure saponite. However, the fluid autoclaved at $600^{\circ} \mathrm{F}$ only reaches a maximum of $75.9 \mathrm{cp}$ at $425^{\circ} \mathrm{F}$ compared to $165.0 \mathrm{cp}$ at $425^{\circ} \mathrm{F}$ for pure saponite. The addition of sepiolite to the saponite system, therefore, gives a viscosity enhancement to the fluid at elevated temperatures. This appears to result from the conversion of the fibrous sepiolite to a smectite, stevensite, with a thin film morphology. A typical stevensite that was formed in the fluid is illustrated in Figure 13c. The transformation mechanism of this reaction was described by Guven et al., (1982). Although the conversion begins at $300^{\circ} \mathrm{F}$, the reaction rate increases rapidly with higher temperatures.

The rest of the fluid data obtained with the Fann 35A viscometer, API and HP.HT filter presses are given in Table 8. Values for gel strengths, apparent and plastic viscosity decrease initially from the unautoclaved fluid $\left(70^{\circ} \mathrm{F}\right)$ to the fluid autoclaved at ${ }^{300^{\circ}} \mathrm{F}$. However, above this temperature range values generally increase. This appears to result from the gradual transition of fibrous sepiolite into thin films of smectite with increasing temperatures. The newly formed smectite films have a greater resistance to flow (increasing the apparent viscosity) and exhibit a subsequent increase in surface area (increasing the plastic viscosity). Similarly, the electrostatic charges of smectite layers, in contrast to the neutral sepiolite fibers, contribute to the increase in yield point and gel strengths. Furthermore, the conversion of sepiolite to smectite results in a considerable improvement in filtration properties. This can be seen by a significant drop in fluid loss from $90 \mathrm{ml} / 30 \mathrm{~min}$ for the unautoclaved fluid to $40 \mathrm{ml} / 30 \mathrm{~min}$ for the fluid autoclaved at $600^{\circ} \mathrm{F}$. The CEC increases from 49 to $79 \mathrm{meq} / 100$ grams from 70 to $500^{2} \mathrm{~F}$, respectively, indicating an increase in surface area. However, CEC drops to $62.9 \mathrm{meq} / 100$ grams at $600^{\circ} \mathrm{F}$, which suggests a change in the mode of aggregation or possibly a slight decomposition of clay particles. The fluid $\mathrm{pH}$ decreases with subsequent levels of 
TABLE 8

PROPERTIES OF THE UNTREATED AND AUTOCLAVED FLUIDS CONSISTING OF $6 \%$ SAPONITE-SEPIOLITE

\begin{tabular}{lccccc}
\hline \multicolumn{1}{c}{ Fluid Properties } & \multicolumn{3}{c}{ Autoclaved at temperatures ( ${ }^{\circ} \mathrm{F}$ ) } \\
\hline & 70 & 300 & 400 & 500 & 600 \\
\hline Apparent Viscosity (centipoise) & 27 & 10 & 12 & 25 & 28 \\
Plastic Viscosity (centipoise) & 5 & 5 & 10 & 13 & 10 \\
Yield Point (lb/100 sq ft) & 44 & 10 & 3 & 23 & 35 \\
Gel Strength (lb/100 sq ft) & $36 / 47$ & $10 / 15$ & $3 / 11$ & $17 / 29$ & $13 / 30$ \\
API Filtrate (ml/30 min) & 18 & 16 & 16 & 14 & 15 \\
Cake Thickness (inches) & $2 / 32$ & $3 / 32$ & $2 / 32$ & $3 / 32$ & $3 / 32$ \\
HP-HT Filtrate (ml/30 min) & 90 & 76 & 56 & 48 & 40 \\
HP-HT Cake Thickness (inches) & $8 / 32$ & $11 / 32$ & $8 / 32$ & $9 / 32$ & $8 / 32$ \\
CEC (milliequivalents/100 gms) & 49 & 55 & 71 & 79 & 63 \\
Surface Area (m ${ }^{2} / \mathrm{g}$ ) & 385 & 430 & 553 & 620 & 492 \\
pH & 9.1 & 8.0 & 8.0 & 8.1 & 8.3 \\
\hline
\end{tabular}


autoclaving. This is in agreement with the reaction mechanism for the conversion of sepiolite to smectite as documented by Guven and Carney (1979) and Guven et al. (1982).

$X$-ray diffraction analysis shows that saponite and sepiolite reflections superimpose in the air-dried state, but resolve into their respective $16.7 \AA$ and $12.1 \AA$ basal spacings upon glycolation. The fluid autoclaved at $300^{\circ} \mathrm{F}$ shows an appreciable conversion of sepiolite into smectite (approximately $60 \%$ ). A basal spacing range of 15.0 to $12.8 \AA$ seems to indicate a heterogenous mixture of interlayer cations ( $\mathrm{Na}, \mathrm{Ca}$, and $\mathrm{Mg}$ ), including two and one molecular layers of water, respectively. At $400^{\circ} \mathrm{F}$, the sepiolite to smectite conversion mechanism is complete. It was earlier proposed by Guven and Carney (1979) and Guven et al. (1982) that a $\mathrm{n}$-glide mechanism is responsible for the conversion of sepiolite to smectite (stevensite). Without further mention, it will be understood that the conversion of sepiolite to smectite is of the stevensite variety, and shall predominate throughout the remainder of the fluid systems. Free $\mathrm{Ca}^{2}+$ in solution readily precipitates in small amounts as calcite in the fluids autoclaved from 300 to $500^{\circ} \mathrm{F}$.

\section{Saponite-Sepiolite / High Molecular Weight Polymer Fluids}

The initial viscosity of the unautoclaved fluid is significantly higher than the pure saponite-sepiolite fluid, but much lower than the bentonite/high molecular weight polymer fluid. The fluid is thinned considerably from $58.5 \mathrm{cp}$ at $7^{\circ} \mathrm{F}$ to $8.0 \mathrm{cp}$ at $400^{\circ} \mathrm{F}$ (as measured with the Fann $50 \mathrm{C}$ viscometer) and then increases slightly to $16.4 \mathrm{cp}$ at $450^{\circ} \mathrm{F}$ (Figure 14). The fluids autoclaved at 300 and $400^{\circ} \mathrm{F}$ display a dramatic decrease in all rheological properties as illustrated in Figure 14 and Table 9. The fluid autoclaved at $500^{\circ} \mathrm{F}$ exhibits a slight increase of initial viscosity at room temperature, but also thins with temperature. Each of the fluids experience a "slight" increase in viscosity between 375 and $475^{\circ} \mathrm{F}$, however, it is apparent that high molecular weight polymer thins the fluid, and eliminates or drastically reduces the anomalous viscosity enhancement at high temperatures. 


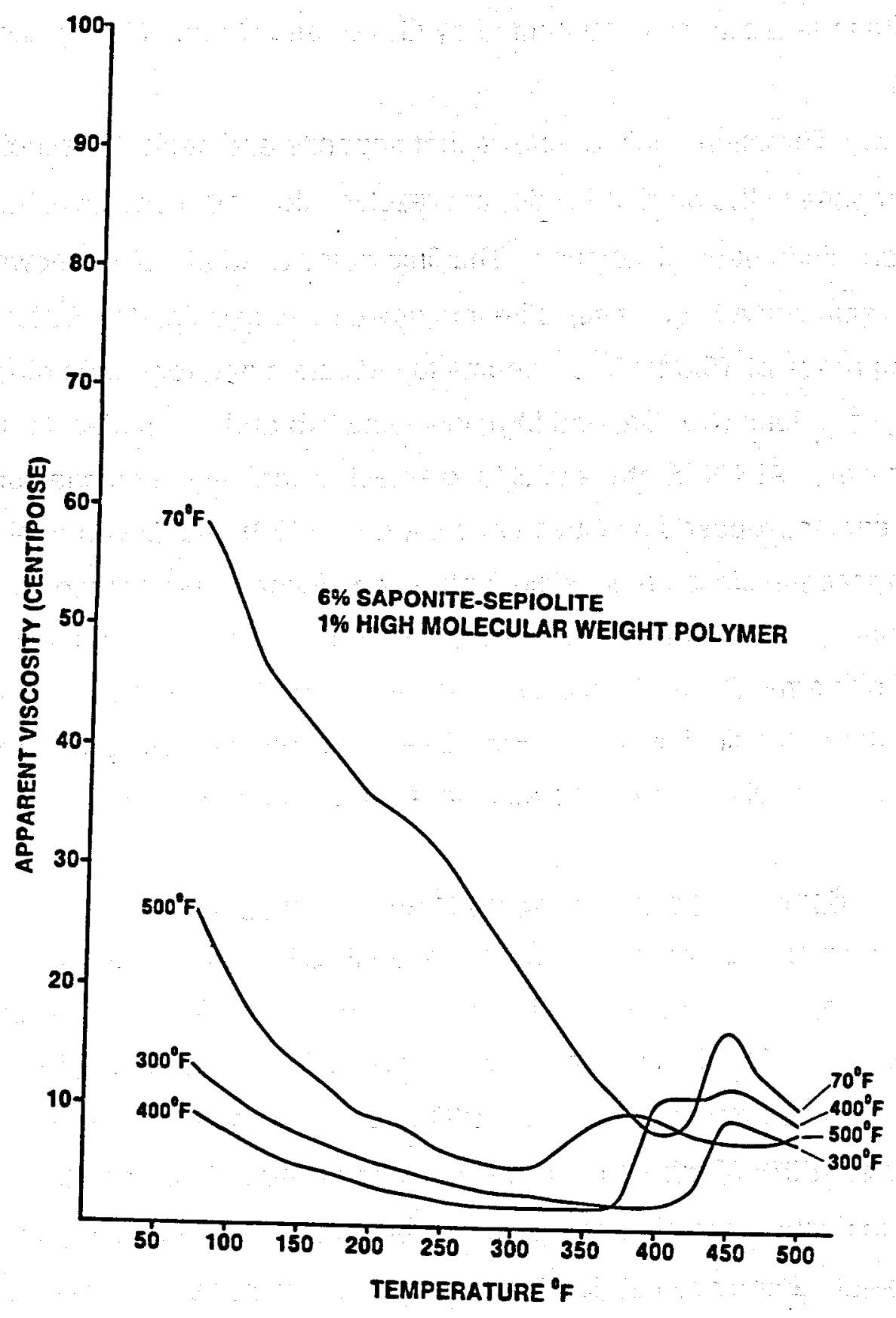

Figure 14. Viscosity profiles of $6 \%$ saponite-sepiolite $/ 1 \%$ high molecular weight polymer fluids autoclaved at various temperatures. 
TABLE 9

PROPERTIES OF THE UNTREATED AND AUTOCLAVED FLUIDS CONSISTING OF $6 \%$ SAPONITE-SEPIOLITE/1\% HIGH MOLECULAR WEIGHT POLYMER

\begin{tabular}{lcccc}
\hline Fluid Properties & \multicolumn{3}{c}{ Autoclaved at temperatures ( ${ }^{\circ} \mathrm{F}$ ) } \\
\hline & 70 & 300 & 400 & 500 \\
\hline Apparent Viscosity (centipoise) & 48 & 12 & 13 & 40 \\
Plastic Viscosity (centipoise) & 35 & 10 & 11 & 30 \\
Yield Point (lb/100 sq ft) & 26 & 3 & 3 & 20 \\
Gel Strength (lb/100 sq ft) & $4 / 7$ & $1 / 2$ & $1 / 2$ & $4 / 10$ \\
API Filtrate (ml/30 min) & 5 & 4 & 5 & 6 \\
Cake Thickness (inches) & $2 / 32$ & $1 / 32$ & $1 / 32$ & $2 / 32$ \\
HP-HT Filtrate (ml/30 min) & 32 & 22 & 30 & 30 \\
HP-HT Cake Thickness (inches) & $2 / 32$ & $2 / 32$ & $2 / 32$ & $3 / 32$ \\
CEC (milliequivalents/100 gms) & 66 & 66 & 78 & 84 \\
Surface Area (m ${ }^{2} / \mathrm{g}$ ) & 517 & 516 & 607 & 655 \\
pH & 8.3 & 8.7 & 8.4 & 8.2 \\
\hline
\end{tabular}


The API and HP-HT filtration losses of the fluids are listed in Table 9. API filtrate remains stable at $5 \mathrm{ml} / 30 \mathrm{~min}$ for all fluids. It is important to note that the addition of high molecular weight polymer reduces the unautoclaved HP-HT filtrate to $32 \mathrm{ml} / 30$ min as compared to $90 \mathrm{ml} / 30 \mathrm{~min}$ for the fluid without the polymer. In fact, the HP-HT fluid loss remains rather low at all temperatures, indicating that the addition of high molecular weight polymer enhances the filtration control of these fluids.

The CEC remains at $66 \mathrm{meq} / 100 \mathrm{~g}$ for the unautoclaved and the $300^{\circ} \mathrm{F}$ fluids, suggesting that sepiolite remains intact, but increases to 78 and $84 \mathrm{meq} / 100 \mathrm{~g}$ for the fluids autoclaved at 400 and $500^{\circ} \mathrm{F}$, respectively. Surface area and the CEC increase at high temperatures, and the fluid $\mathrm{pH}$ remains slightly alkaline (8.2 to 8.7).

$X$-ray diffraction analysis indicates that high molecular weight polymer also hinders the conversion of sepiolite to smectite. After autoclaving at $300^{\circ} \mathrm{F}$, there appears to be no appreciable change in the relative proportion of saponite to sepiolite. At $400^{\circ} \mathrm{F}$, however, $65 \%$ of the sepiolite is converted to smectite and by $500^{2} \mathrm{~F}$ the conversion rate is complete. The polymer begins to decompose above $300^{\circ} \mathrm{F}$, however, it remains stable until the conversion of sepiolite to stevensite enhances fluid properties. There are no major mineral reactions present in these fluids. The addition of high molecular weight polymer promotes the formation of a calcium acrylate, which inhibits the precipitation of calcite as seen in the pure saponite-sepiolite system.

\section{8\% Saponite-Sepiloite / High molecular Weight Polymer Fluids}

Figure 15 shows that a relative increase in the clay to polymer ratio, increases the fluid viscosity. The $70-400^{\circ} \mathrm{F}$ fluids exhibit a more pronounced viscosity enhancement between 350 and 450\% F. The fluid autoclaved at 500' F; however, experiences a broad viscosity "hump" between 200 and $400^{\circ} \mathrm{F}$. The ability of high molecular weight polmer to control fluid properties is a function of the polymer to clay ratio.

Other rheological properties are listed in Table 10. The API and HP-HT values 


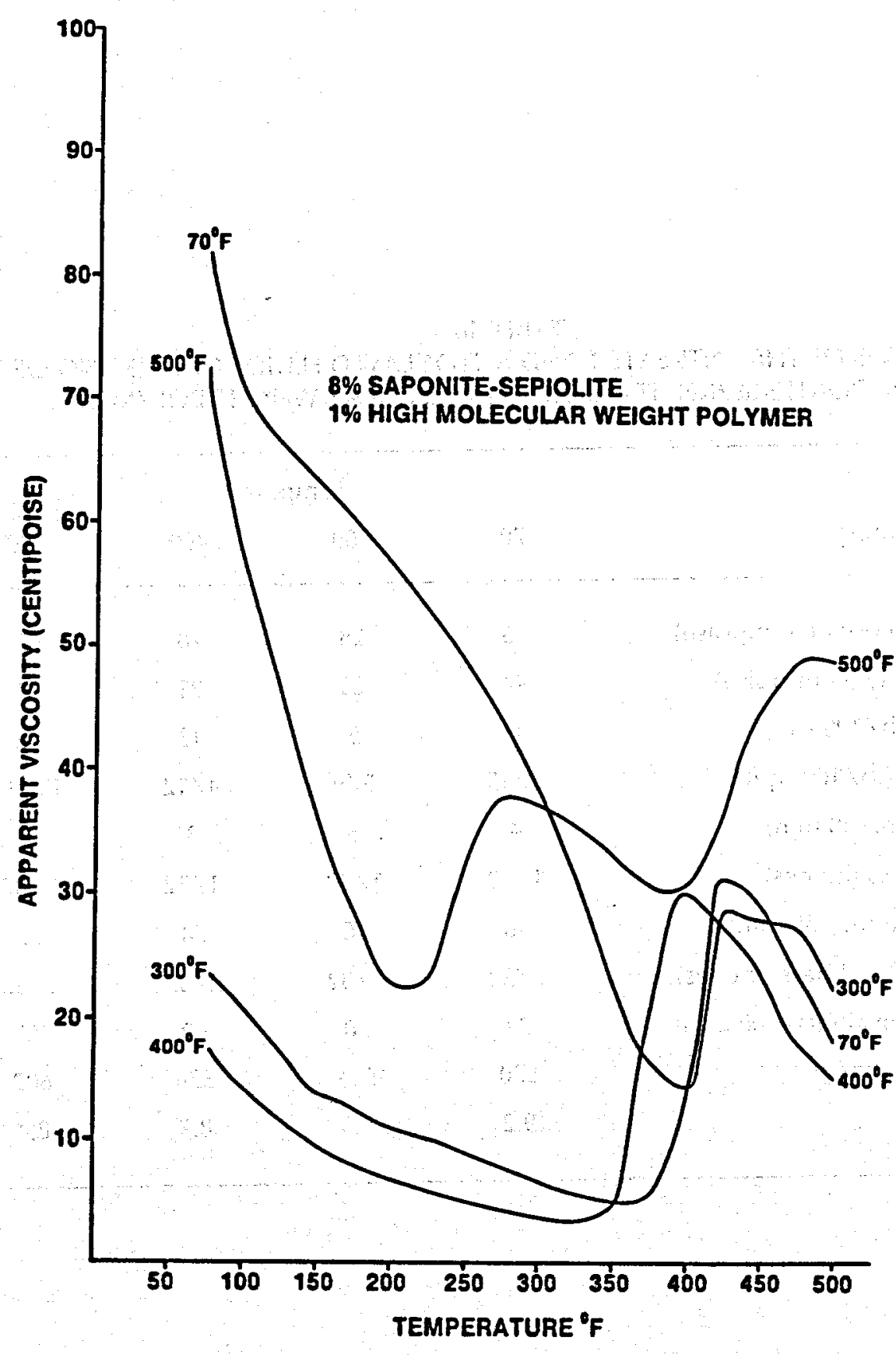

Figure 15. Viscosity profiles of $8 \%$ saponite-sepiolite $/ 7 \%$ high molecular weight polymer fluids autoclaved at various temperatures. 
TABLE 10

PROPERTIES OF THE UNTREATED AND AUTOCLAVED FLUIDS CONSISTING OF 8\% SAPONITE-SEPIOLITE/1\% HIGH MOLECULAR WEIGHT POLYMER

\begin{tabular}{lcccc}
\hline \multicolumn{1}{c}{ Fluid Properties } & \multicolumn{3}{c}{ Temp. ( ${ }^{\circ} \mathrm{F}$ ) } \\
& 70 & 300 & 400 & 500 \\
\hline Apparent Viscosity (centipoise) & 65 & 28 & 28 & 67 \\
Plastic Viscosity (centipoise) & 44 & 25 & 21 & 41 \\
Yield Point (lb/100 sq ft) & 41 & 5 & 13 & 52 \\
Gel Strength (lb/100 sq ft) & $8 / 15$ & $5 / 9$ & $4 / 12$ & $13 / 31$ \\
API Filtrate (ml/30 min) & 4 & 3 & 3 & 4 \\
Cake Thickness (inches) & $1 / 32$ & $1 / 32$ & $1 / 32$ & $1 / 32$ \\
HP-HT Filtrate (ml/30 min) & 16 & 16 & 24 & 22 \\
HP-HT Cake Thickness (inches) & $2 / 32$ & $2 / 32$ & $2 / 32$ & $3 / 32$ \\
CEC (milliequivalents/100 gms) & 73 & 70 & 69 & 77 \\
Surface Area (m ${ }^{2} / \mathrm{g}$ ) & 570 & 544 & 538 & 602 \\
pH & 9.2 & 8.8 & 8.7 & 8.4 \\
\hline
\end{tabular}


are very low. They exhibit a significant decrease in fluid loss compared to the $6 \%$ saponite-sepiolite/ $1 \%$ high molecular weight polymer system. This change reflects an increase in solids per unit volume of fluid.

The mineralogical changes in this fluid system are analogous to the previous fluid system. The sepiolite - to - smectite conversion rate is very similar with the exception of the fluid autoclaved at $400^{\circ} \mathrm{F}$, which shows a $55 \%$ rate of conversion. The basal spacing of saponite remains stable throughout the appropriate temperature range at $15.0 \AA$ in the air-dried state and expands to $16.7 \AA$ upon glycolation.

\section{Saponite-Sepiolite/Low Molecular Weight Polymer Fluids}

Rheological and fluid loss data of the $6 \%$ saponite- sepiolite $/ 1 \%$ low molecular weight polymer fluids is listed in Figure 16 and Table 11. This fluid system could not be heated to 500 or $600^{\circ} \mathrm{F}$ due to the nature of the polymer upon the autoclave. The viscosity profiles illustrate the thinning nature of this polymer (Figure 16). In fact, it completely eliminates the viscosity anomaly as previously seen in the pure $6 \%$ saponite-sepiolite system.

Table 11 summarizes other rheological properties. The apparent and plastic viscosity have increased slightly with temperature from 4 to $7 \mathrm{cp}$ and 3 to $7 \mathrm{cp}$, respectively. Both yield point and gel strength remain unchanged throughout the appropriate temperature range $\left(70-400^{\circ} \mathrm{F}\right)$. The API and HP-HT fluid losses have improved compared to the basic $6 \%$ saponite-sepiolite fluid system; both show a decrease in discharged filtrate from 70 to $400^{\circ} \mathrm{F}$. CEC has increased slightly, and pH has decreased as expected.

The addition of low molecular weight polymer hinders the conversion of sepiolite to smectite while autoclaving at $300^{2} \mathrm{~F}$, as no relative change in reflection intensities were detected with $x$-ray diffraction. The saponite and sepiolite reflections superimpose in the air-dried state and separate to their respective $16.8 \AA$ and $12.1 \AA$ basal spacings after glycolation. After autoclaving at $400^{\circ} \mathrm{F}$, the conversion rate is 


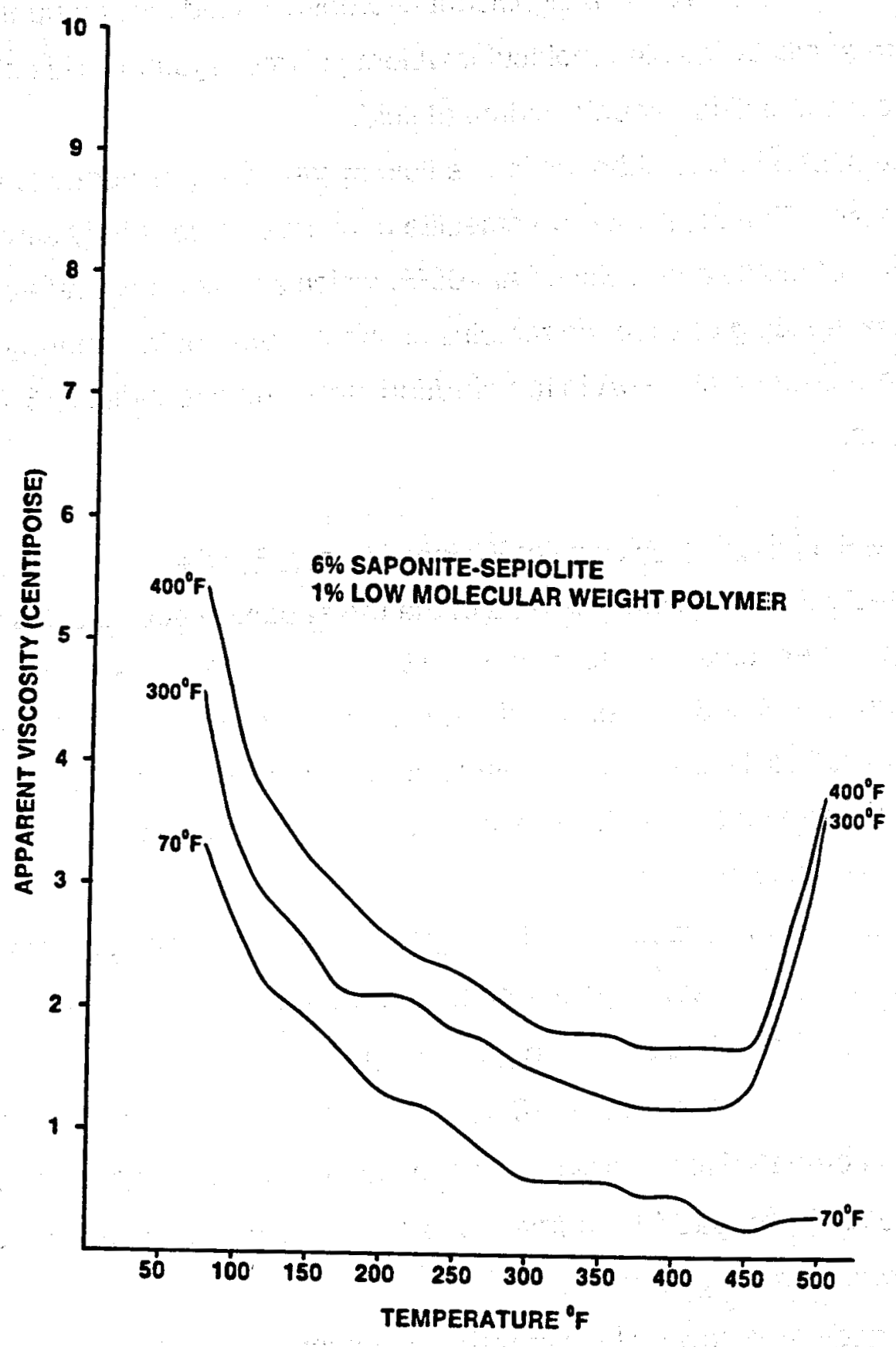

Figure 16. Viscosity profiles of $6 \%$ saponite-sepiolite $/ 1 \%$ low molecular weight polymer fluids autoclaved at various temperatures. 
PROPERTIES OF THE UNTREATED AND AUTOCLAVED FLUIDS CONSISTING OF 6\% SAPONITE-SEPIOLITE/1\% LOW MOLECULAR WEIGHT POLYMER

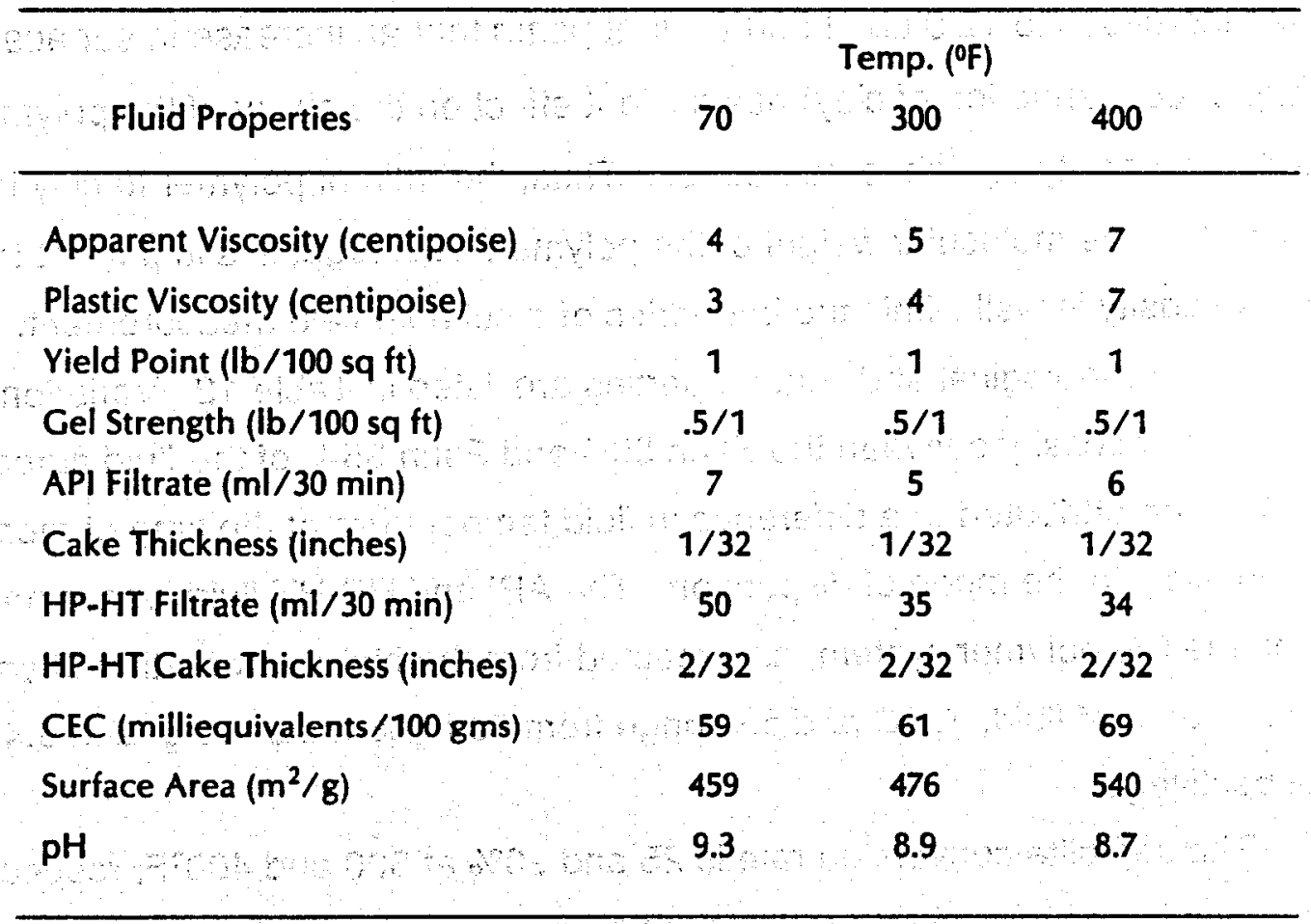


$85 \%$. It appears that the polymer begins to break down above $300^{\circ} \mathrm{F}$, thus the properties of the clays become the dominant factor for fluid control above $300^{\circ} \mathrm{F}$.

\section{8\% Saponite-Sepiolite / Low Molecular Weight Polymer Fluids}

The previous polymer system discussed was increased to an $8 \%$ concentration of clay. The viscosity profiles of the unautoclaved $\left(70^{\circ} \mathrm{F}\right)$ and the fluid autoclaved at $300^{\circ} \mathrm{F}$ are very similar to that of the previous polymer system. They exhibit only a slight increase in viscosity and remain between 1.5 and $7.0 \mathrm{cp}$ (Figure 17). The fluid autoclaved at $400^{\circ} \mathrm{F}$ has an initial viscosity of $20.9 \mathrm{cp}$, thins to $4.5 \mathrm{cp}$ at $350^{\circ} \mathrm{F}$, and then increases to $12.9 \mathrm{cp}$ at $500^{\circ} \mathrm{F}$. It appears that an increase in surface area (higher concentration of clay) has a slight effect on the ability of the polymer to control viscosity at high temperatures. Thus, the ratio of polymer to clay is important, as well as the molecular weight of the polymer. Although, it is important to note that this viscosity is well within the boundries of a suitable field measurement.

Other rheological and fluid properties are listed in Table 12. Variations in apparent viscosity between the Fann $50 \mathrm{C}$ and Fann $35 \mathrm{~A}$, of the fluid autoclaved at $400^{\circ} \mathrm{F}$, are attributed to a difference in fluid temperature at the time of measurement, or possibly to the mode of dispersion. The API and HP-HT fluid losses are lower than the $6 \%$ polymer system, as expected from the higher proportion of solids per unit volumn of fluid. CEC and $\mathrm{pH}$ range from 59 to $66 \mathrm{meq} / 100 \mathrm{~g}$ and 9.4 to 8.4, respectively.

The sepiolite conversion rate is 25 and $90 \%$ at 300 and $400^{\circ} \mathrm{F}$, respectively. The increase in conversion rate reflects the relative proportion of clay concentration to low molecular weight polymer. Once again, the polymer complex begins to break down above $300^{\circ} \mathrm{F}$.

\section{Saponite-Sepiolite / $\mathrm{CaCl}_{2}$ Fluids}

The ability of saponite-sepiolite fluids to maintain any favorable rheological 


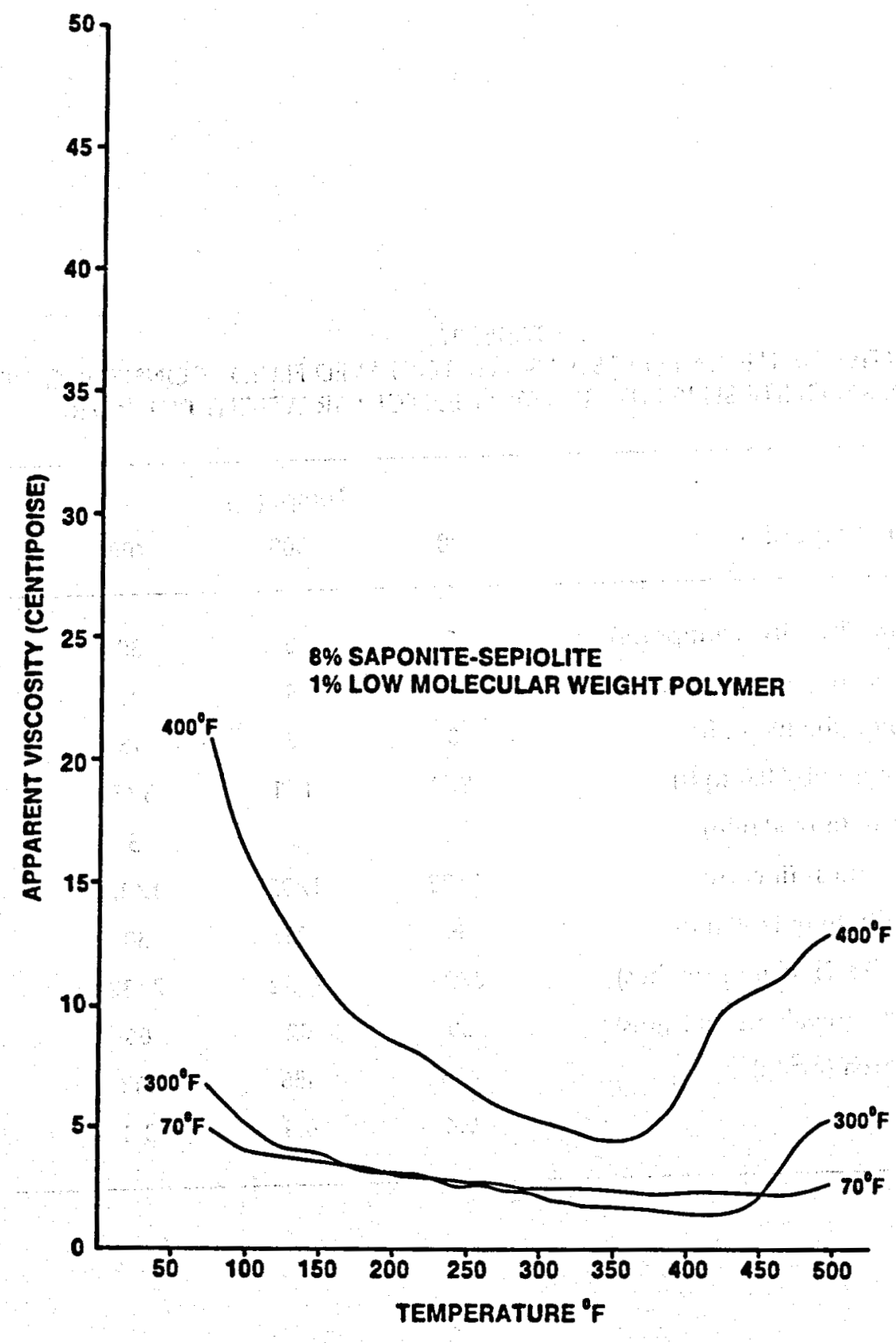

Figure 17. Viscosity profiles of $8 \%$ saponite-sepiolite $/ 1 \%$ low molecular weight polymer fluids autoclaved at various temperatures. 
TABLE 12

PROPERTIES OF THE UNTREATED AND AUTOCLAVED FLUIDS CONSISTING OF 8\% SAPONITE-SEPIOLITE/1\% LOW MOLECULAR WEIGHT POLYMER

\begin{tabular}{lccc}
\hline \multicolumn{1}{c}{ Fluid Properties } & Temp. (0F) \\
& 70 & 300 & 400 \\
\hline Apparent Viscosity (centipoise) & 5 & 8 & 30 \\
Plastic Viscosity (centipoise) & 5 & 5 & 22 \\
Yield Point (lb/100 sq ft) & 0 & 2 & 16 \\
Gel Strength (lb/100 sq ft) & $.5 / 1$ & $1 / 1$ & $3 / 5$ \\
API Filtrate (ml/30 min) & 4 & 5 & 5 \\
Cake Thickness (inches) & $1 / 32$ & $1 / 32$ & $1 / 32$ \\
HP-HT Filtrate (ml/30 min) & 36 & 25 & 30 \\
HP-HT Cake Thickness (inches) & $2 / 32$ & $2 / 32$ & $2 / 32$ \\
CEC (milliequivalents/100 gms) & 59 & 62 & 66 \\
Surface Area (m ${ }^{2} / g$ ) & 458 & 486 & 513 \\
pH & 9.4 & 8.9 & 8.4 \\
\hline
\end{tabular}


properties in the presence of calcium chloride is negligible. These properties remain extremely low at all temperatures as illustrated in Figure 18 and Table 13. The API and HP-HT fluid losses are very high at all temperatures. The $\mathrm{Ca}^{2+}$ ion promotes the flocculation of clay particles which leads to the deterioration of fluid properties. Individual clay particles are arranged into flocks with a smaller surface area which is exposed to the fluid. Consequently, the CEC values are relatively low. The fluid $\mathrm{pH}$ remains somewhat neutral ranging from 7.5 at $70^{\circ} \mathrm{F}$ to 7.0 at $600^{\circ} \mathrm{F}$.

$X$-ray diffraction analysis shows a sharp $15.2 \AA$ reflection that indicates $\mathrm{Ca}^{2}+$ is the predominant interlayer cation with two molecular layers of water. The addition of $\mathrm{CaCl}_{2}$ hinders the formation of smectite at $300^{\circ} \mathrm{F}$, as only 5 to $10 \%$ sepiolite was converted to stevensite. However, similar to the pure saponite-sepiolite system, the conversion is complete after autoclaving at $400^{\circ} \mathrm{F}$. The presence of free $\mathrm{Ca}^{2+}$ in solution readily leads to the precipitation of calcite in the fluids that were autoclaved at 300 and $400^{\circ} \mathrm{F}$.

\section{Saponite-Sepiolite / $\mathrm{Ca}(\mathrm{OH})_{2}$ Fluids}

The rheological properties of $6 \%$ saponite-sepiolite $/ 1 \% \mathrm{Ca}(\mathrm{OH})_{2}$ fluids are summarized in Figure 19 and Table 14. The viscosities of these fluids are relatively low at all temperatures with the exception of the fluid autoclaved at $300^{\circ} \mathrm{F}$. Similar to the calcium chloride system, calcium hydroxide is also extremely detrimental to fluid loss and wall-building properties. Table 14 shows that both API and HP-HT filtrate are very high. Furthermore, the presence of $\mathrm{Ca}(\mathrm{OH})_{2}$ also promotes the flocculation of clay particles, as CEC values are rather low. The $\mathrm{pH}$ of the initial fluid is highly alkaline (12.3 at $\left.70^{\circ} \mathrm{F}\right)$ and drops to 9.3 at $600^{\circ} \mathrm{F}$.

The addition of $\mathrm{Ca}(\mathrm{OH}) 2$ seems to promote the conversion of sepiolite to smectite. $X$-ray diffraction indicates that the conversion rate is complete after autoclaving at $300^{\circ} \mathrm{F}$. Saponite has a basal spacing of $15.3 \AA$ in the air-dried state and swells to $16.7 \AA$ upon glycolation. These values remain rather stable throughout 


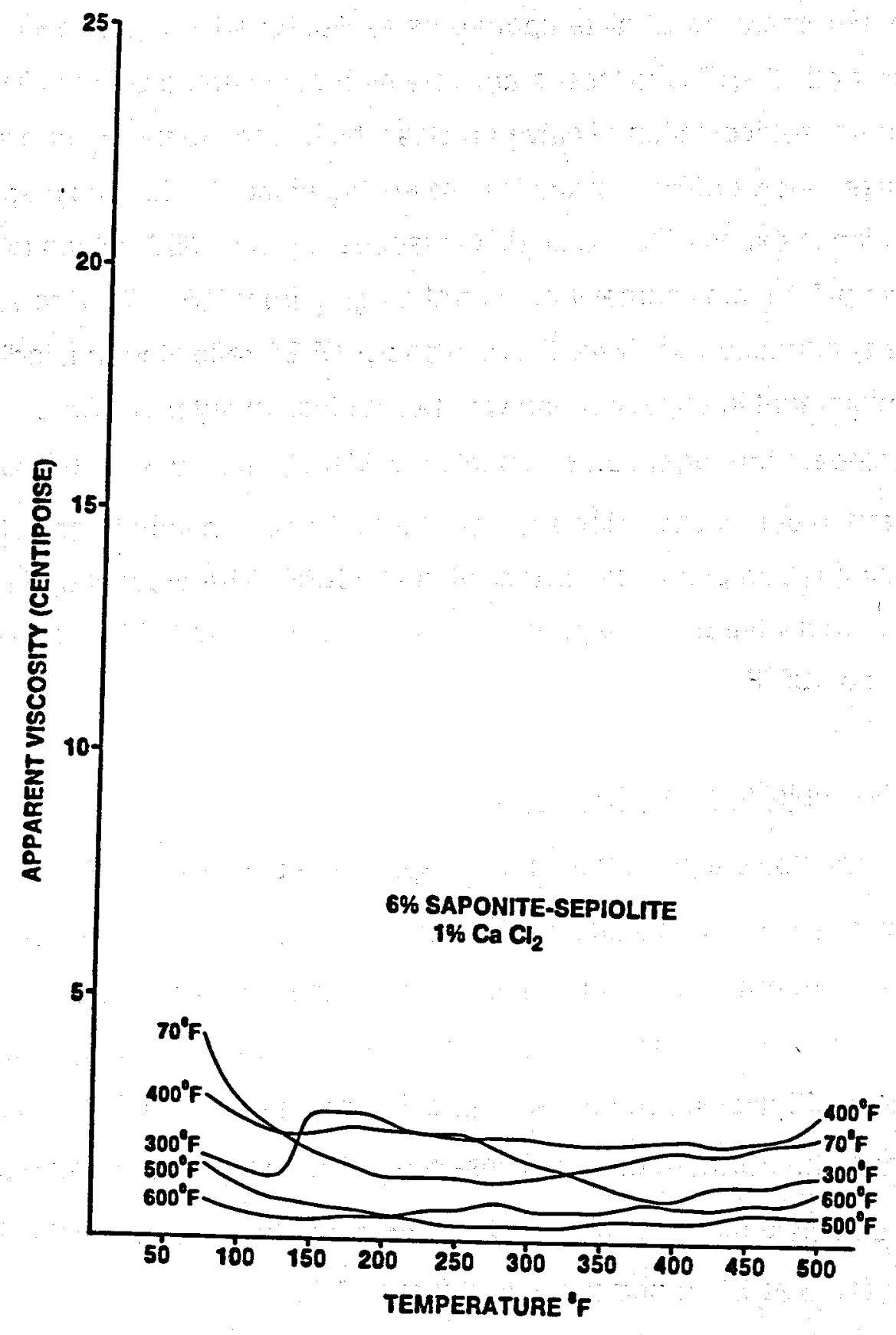

Figure 18. Viscosity profiles of $6 \%$ saponite-sepiolite $/ 1 \% \mathrm{CaCl}_{2}$ fluids autoclaved at various temperatures. 
TABLE 13

PROPERTIES OF THE UNTREATED AND AUTOCLAVED FLUIDS CONSISTING OF

$6 \%$ SAPONITE-SEPIOLITE $/ 1 \% \mathrm{CaCl}_{2}$

\begin{tabular}{lccccc}
\hline \multicolumn{1}{c}{ Fluid Properties } & \multicolumn{3}{c}{ Autoclaved at temperatures ( ${ }^{\circ}$ ) } \\
& 70 & 300 & 400 & 500 & 600 \\
\hline Apparent Viscosity (centipoise) & 5 & 4 & 4 & 2 & 2 \\
Plastic Viscosity (centipoise) & 2 & 2 & 2 & 1 & 1 \\
Yield Point (lb/100 sq ft) & 9 & 3 & 3 & 2 & 1 \\
Gel Strength (lb/100 sq ft) & $5 / 7$ & $3 / 10$ & $3 / 7$ & $1 / 1$ & $.5 / 1$ \\
API Filtrate (ml/30 min) & 72 & 114 & 102 & 170 & 206 \\
Cake Thickness (inches) & $4 / 32$ & $6 / 32$ & $6 / 32$ & $4 / 32$ & $5 / 32$ \\
HP-HT Filtrate (ml/30 min) & $238 / 11$ & $252 / 6$ & $248 / 7$ & $244 / 7$ & $265 / 5$ \\
HP-HT Cake Thickness (inches) & $4 / 32$ & $6 / 32$ & $7 / 32$ & $6 / 32$ &.- \\
CEC (milliequivalents/100 gms) & 38 & 45 & 60 & 57 & 53 \\
Surface Area (m ${ }^{2} / \mathrm{g}$ ) & 300 & 355 & 466 & 443 & 412 \\
pH & 7.5 & 6.9 & 6.8 & 6.7 & 7.0 \\
\hline
\end{tabular}

*The amount of filtrate and time (in minutes) when the blowout occurs. 


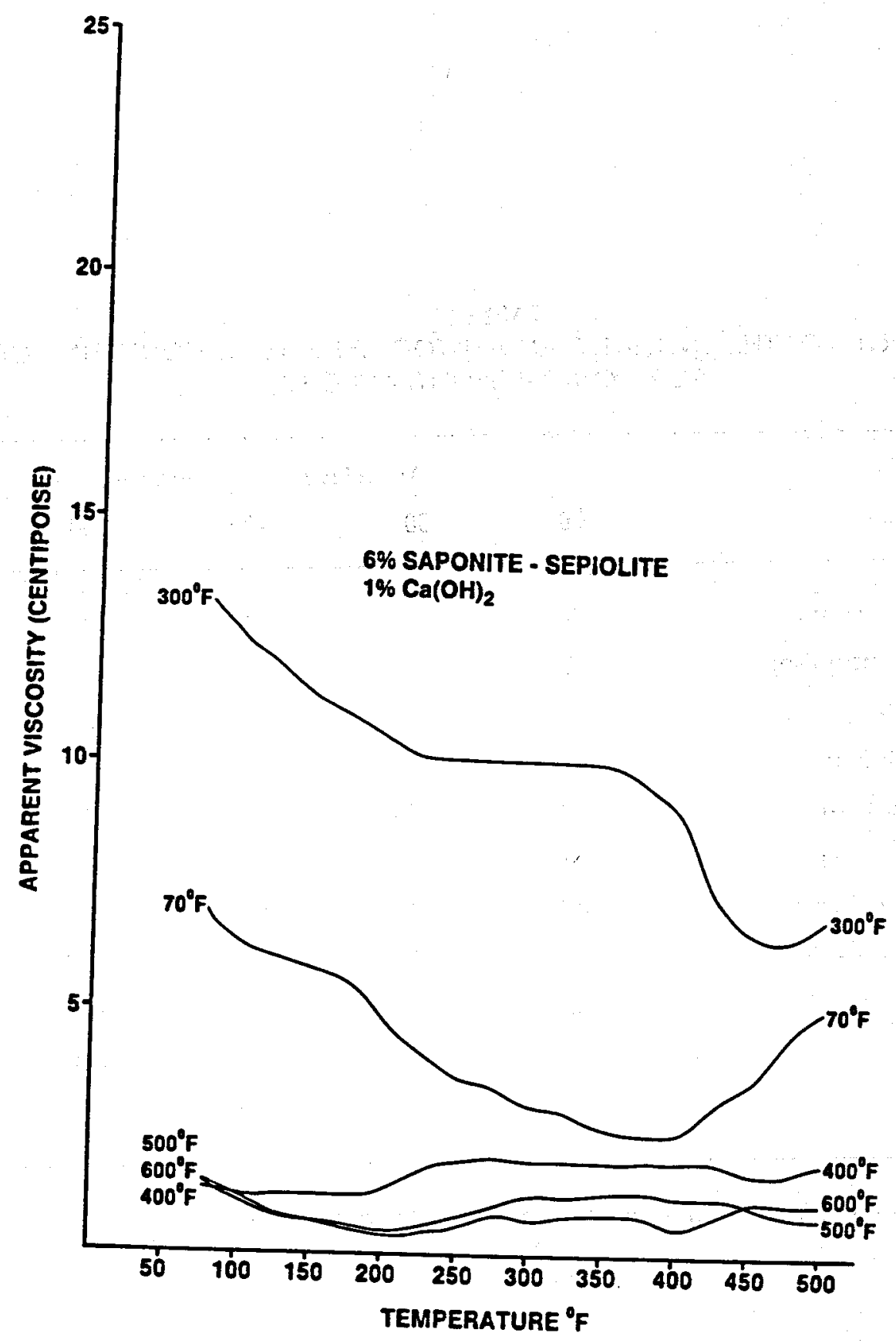

Figure 19. Viscosity profiles of $6 \%$ saponite-sepiolite $/ 1 \% \mathrm{Ca}(\mathrm{OH})_{2}$ fluids autoclaved at various temperatures. 
TABLE 14

PROPERTIES OF THE UNTREATED AND AUTOCLAVED FLUIDS CONSISTING OF $6 \%$ SAPONITE-SEPIOLITE/1\% $\mathrm{Ca}(\mathrm{OH})_{2}$

\begin{tabular}{|c|c|c|c|c|c|}
\hline \multirow{2}{*}{ Fluid Properties } & \multicolumn{5}{|c|}{ Autoclaved at temperatures $\left({ }^{\circ} \mathrm{F}\right)$} \\
\hline & 70 & 300 & 400 & 500 & 600 \\
\hline Apparent Viscosity (centipoise) & 6 & 10 & 2 & 2 & 2 \\
\hline Plastic Viscosity (centipoise) & 2 & 13 & 1 & 2 & 1 \\
\hline Yield Point (lb/100 sq ft) & 7 & 14 & 1 & 0 & 1 \\
\hline Gel Strength (lb/100 sq ft) & $3 / 4$ & $10 / 13$ & $.5 / 1$ & $.5 / .5$ & $.5 / .5$ \\
\hline API Filtrate $(\mathrm{ml} / 30 \mathrm{~min})$ & 208 & 754 & 136 & 96 & $\cdots$ \\
\hline Cake Thickness (inches) & $7 / 32$ & $4 / 32$ & $4 / 32$ & $6 / 32$ & -- \\
\hline HP-HT Filtrate $(\mathrm{ml} / 30 \mathrm{~min})^{*}$ & $170 / 1$ & $172 / 2$ & $222 / 6$ & $238 / 16$ & 180 \\
\hline HP-HT Cake Thickness (inches) & $9 / 32$ & $4 / 32$ & $6 / 32$ & $10 / 32$ & $10 / 32$ \\
\hline CEC (milliequivalents $/ 100$ gms) & 23 & 42 & 52 & 47 & 40 \\
\hline Surface Area $\left(\mathrm{m}^{2} / \mathrm{g}\right)$ & 147 & 326 & 408 & 381 & 309 \\
\hline $\mathrm{pH}$ & 12.3 & 11.3 & 10.0 & 9.6 & 9.3 \\
\hline
\end{tabular}

*The amount of filtrate and time (in minutes) if a blowout was occurred before 30 minutes. 
the appropriate temperature range. The major mineral reactions of this system are calcite and tobermorite. Lime readily converts to calcite at room temperature and at $300^{\circ} \mathrm{F}$. Tobermorite, a hydrated calcium silicate, has a characteristic reflection at 11.3A. This mineral, which seems to form at the expense of sepiolite, is present in trace amounts at $300^{2} \mathrm{~F}$ and in much larger quantities at $400^{\circ} \mathrm{F}$.

\section{Saponite-Sepiolite / KCL Fluids}

The fluid shows a drastic reduction in viscosity with higher temperatures in the presence of $\mathrm{KCl}$ (Figure 20 and Table 15). The initial viscosity drops steadily from $32.3 \mathrm{cp}$ at $75^{\circ} \mathrm{F}$ to $7.5 \mathrm{cp}$ at $500^{\circ} \mathrm{F}$. There is, however, a slight increase in viscosity between 375 and $475^{\circ} \mathrm{F}$. The effect of $\mathrm{KCl}$ as a thinner on fluid rheology is enhanced with subsequent levels of autoclaving. All of the autoclaved fluids exhibit veny low viscosities which range from 15 to $2.5 \mathrm{cp}$ at 70 and 500 $\mathrm{F}$, respectively. As seen in other fluid systems, there is an anomalous viscosity enhancement between 250 and $350^{\circ} \mathrm{F}$, however, it is only a slight increase in this case. Therefore, the addition of $\mathrm{KCl}$ actively controls the rheological properties of saponite-sepiolite fluids in the high temperature regime.

Other fluid properties are summarized in Table 15. It is important to note that the gel strengths are relatively high. In fact, there is a significant increase in readings with an increase in stagnation time. The $\mathrm{K}^{+}$ion seems to promote the thixotropic nature of these fluids. Both API and HP-HT filtrate losses are extremely high at all temperatures. CEC values seem to follow the general pattern familiar to most saponite-sepiolite systems; the CEC increases from 70 to $400^{\circ} \mathrm{F}$ (associated with the conversion of sepiolite to smectite which increases surface area) and drops at $\mathbf{5 0 0}$ and $600^{\circ} \mathrm{F}$ (surface area decreases in this temperature range as the clays begin to break-down). The fluid $\mathrm{pH}$ is moderately alkaline at room temperature ( 8.4 at $70^{\circ} \mathrm{F}$ ) and drops to 7.5 after autoclaving.

The addition of $\mathrm{KCl}$ inhibits the conversion of sepiolite to smectite at $300^{\circ} \mathrm{F}$. Only a trace amount ( $5 \%$ or less) of sepiolite was converted at $300^{\circ} F$, as detected by $x$-ray, 


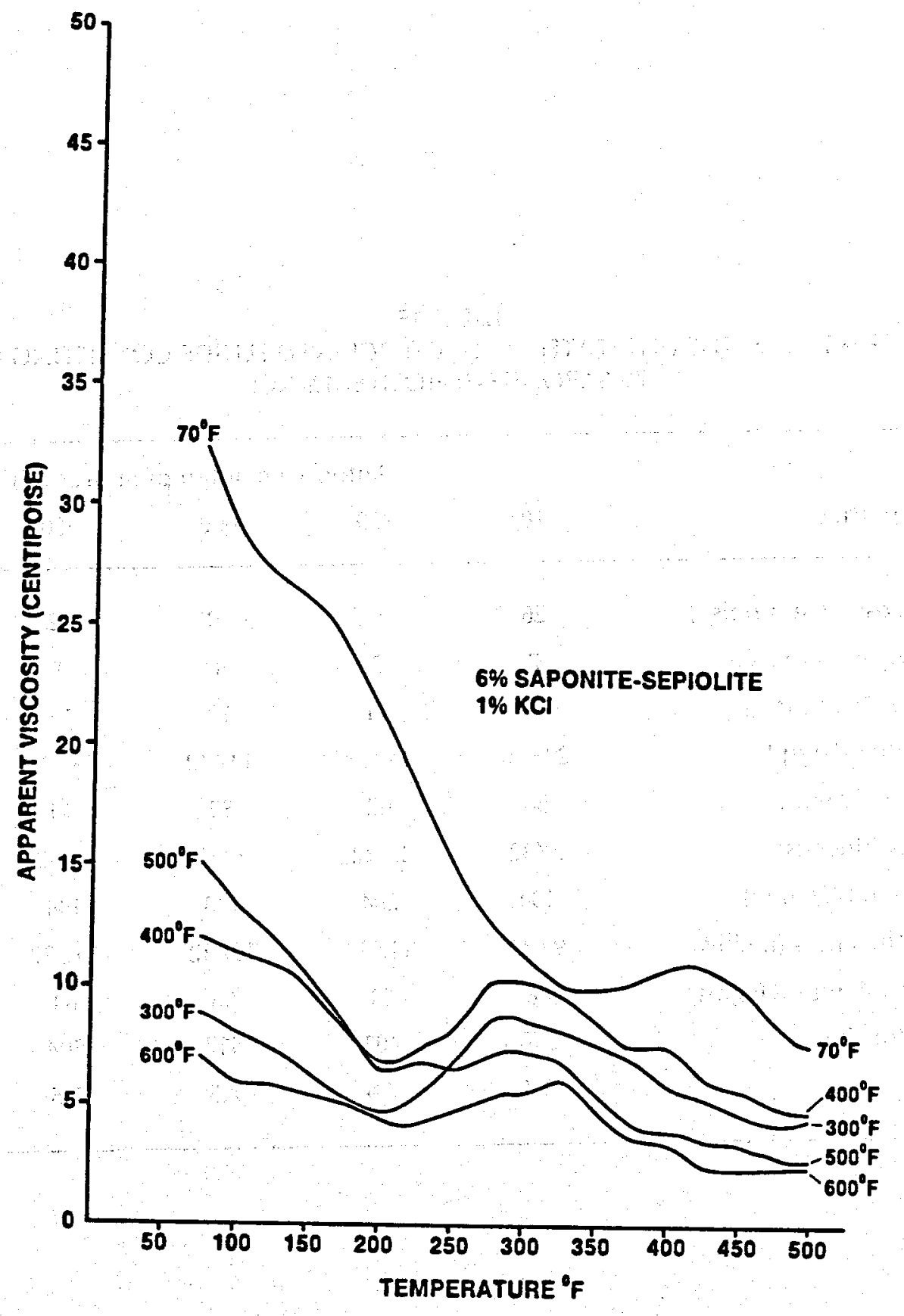

Figure 20. Viscosity profiles of $6 \%$ saponite-sepiolite $/ 1 \% \mathrm{KCl}$ fluids autoclaved at various temperatures. 
TABLE 15

PROPERTIES OF THE UNTREATED AND AUTOCLAVED FLUIDS CONSISTING OF $6 \%$ SAPONITE-SEPIOLITE/7\% KCl

\begin{tabular}{lccccc}
\hline \multicolumn{1}{c}{ Fluid Properties } & \multicolumn{5}{c}{ Autoclaved at temperatures ( ${ }^{\mathrm{O}} \mathrm{F}$ ) } \\
& 70 & 300 & 400 & 500 & 600 \\
\hline Apparent Viscosity (centipoise) & 26 & 9 & 10 & 12 & 6 \\
Plastic Viscosity (centipoise) & 7 & 3 & 4 & 4 & 2 \\
Yield Point (lb/100 sq ft) & 38 & 11 & 12 & 16 & 7 \\
Gel Strength (lb/100 sq ft) & $23 / 30$ & $14 / 38$ & $14 / 40$ & $19 / 46$ & $7 / 77$ \\
API Filtrate (ml/30 min) & 54 & 62 & 52 & 40 & 56 \\
Cake Thickness (inches) & $2 / 32$ & $2 / 32$ & $2 / 32$ & $5 / 32$ & $4 / 32$ \\
HP-HT Filtrate (ml/30 min) & 194 & 204 & 138 & 144 & 182 \\
HP-HT Cake Thickness (inches) & $9 / 32$ & $11 / 32$ & $10 / 32$ & $11 / 32$ & $11 / 32$ \\
CEC (milliequivalents/100 gms) & 46 & 51 & 66 & 64 & 55 \\
Surface Area (m ${ }^{2} / \mathrm{g}$ ) & 358 & 401 & 517 & 504 & 430 \\
pH & 8.4 & 7.4 & 7.5 & 7.5 & 7.7 \\
\hline
\end{tabular}


diffraction. At $400^{\circ} \mathrm{F}$, however, the conversion mechanism is complete. Once again the $15.2 \AA$ reflection of saponite indicates an interlayer arrangement with two molecular layers of water.

Saponite-Sepiolite / KOH Fluids

The rheological properties of the $6 \%$ saponite-sepiolite/ $1 \% \mathrm{KOH}$ fluids are given in Figure 21 and Table 16. Unlike the $\mathrm{KCl}$ fluid, the $70^{\circ} \mathrm{F}$ fluid displays an extremely thin viscosity rheogram. The fluid autoclaved at $300^{\circ} \mathrm{F}$ exhibits a slight viscosity enhancement at $225^{\circ} \mathrm{F}$, but thins to $5.0 \mathrm{cp}$ at $500^{\circ} \mathrm{F}$. The fluids autoclaved at 500 and $600^{\circ} \mathrm{F}$ are also very thin and remain below $5 \mathrm{cp}$ throughout the appropriate temperature range. This may be related to the fact that illite/smectite (I/S) mixed layers, illite, and K-feldspar make up a significant part of these fluids at higher temperatures.

The addition of $\mathrm{KOH}$ is highly detrimental to other fluid properties such as plastic viscosity, yield point, and gel strength (Table 16). There is a noticeable change in API filtrate loss from $42 \mathrm{ml} / 30 \mathrm{~min}$ to $86 \mathrm{ml} / 30 \mathrm{~min}$ at 500 to $600^{\circ} \mathrm{F}$, respectively. Once again, associated with the high temperature mineral reactions. The HP-HT filtrate loss is also very high. The pH drops steadily from 12.7 at $70^{8} \mathrm{~F}$ to 10.4 at $600^{\circ} \mathrm{F}$. The CEC shows an initial increase from 70 to $300^{\circ} \mathrm{F}$, but decreases significantly above this temperature. This reduction in CEC is consistent with the high temperature mineral reactions.

High temperature mineral reactions in these fluids are considerably different from those of other fluids. The saponite and sepiolite reflections superimpose at $12.3 \AA$ in the air-dried state and shift to their respective 16.5 and $12.0 \AA$ basal spacings after glycolation. A smectite reflection at $12.3 \AA$ indicates a clay mineral with one molecular layer of water within its interlayer structure. As opposed to the $\mathrm{KCl}$ fluid, the sepiolite conversion rate is almost complete at $300^{\circ} \mathrm{F}$ (greater than $95 \%$ ). LS mixed-layers, illite and K-feldspar are the major reaction products in these fluids. The formation of U/S mixed layers begin at $500^{\circ} \mathrm{F}$, and by $600^{\circ} \mathrm{F}$ a distinct 


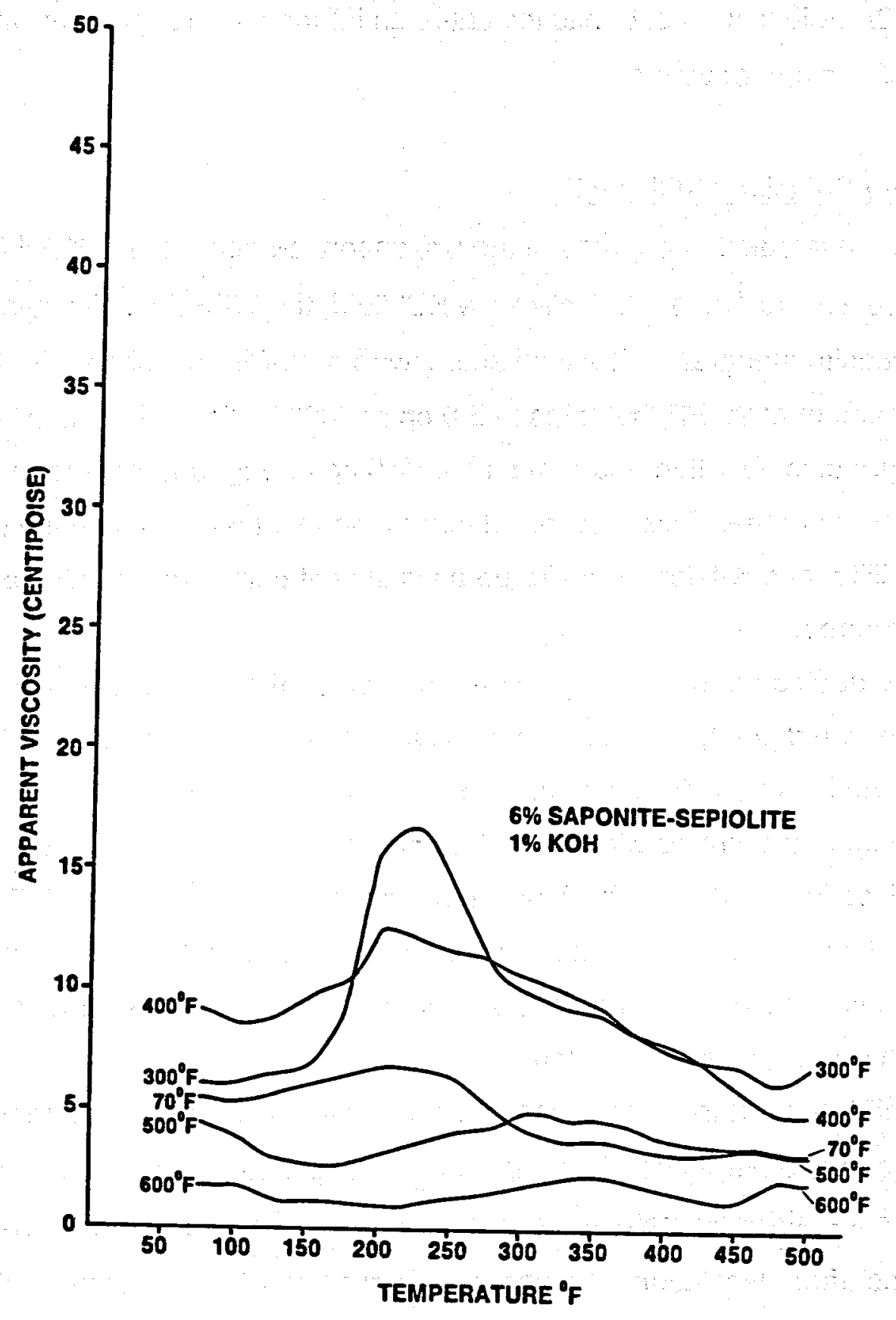

Figure 21. Viscosity profiles of $8 \%$ saponite-sepiolite $/ 1 \% \mathrm{KOH}$ fluids autoclaved at various temperatures. 


\begin{tabular}{|c|c|c|c|c|c|}
\hline \multirow{2}{*}{ Fluid Properties } & \multicolumn{5}{|c|}{ Autoclaved at temperatures ( $\left.{ }^{\circ} \mathrm{F}\right)$} \\
\hline & 70 & 300 & 400 & 500 & 600 \\
\hline Apparent Viscosity (centipoise) & 5 & 3 & 5 & 3 & 3 \\
\hline Plastic Viscosity (centipoise) & 2 & 2 & 4 & 3 & 3 \\
\hline Yield Point (lb/100 sq ft) & 5 & 2 & 2 & 0 & 0 \\
\hline Gel Strength (lb/100 sq ft) & $6 / 10$ & $.5 / 2$ & $.5 / 12$ & $.5 / 1$ & $.5 / 1$ \\
\hline API Filtrate $(\mathrm{ml} / 30 \mathrm{~min})$ & 43 & 51 & 49 & 42 & 86 \\
\hline Cake Thickness (inches) & $3 / 32$ & $5 / 32$ & $6 / 32$ & $6 / 32$ & $4 / 32$ \\
\hline HP-HT Filtrate $(\mathrm{ml} / 30 \mathrm{~min})^{*}$ & $222 / 29$ & $106 / 13$ & 98 & $106 / 3$ & $268 / 28$ \\
\hline HP-HT Cake Thickness (inches) & $12 / 32$ & $6 / 32$ & $10 / 32$ & $3 / 32$ & -- \\
\hline CEC (milliequivalents / $100 \mathrm{gms}$ ) & 50 & 68 & 59 & 48 & 24 \\
\hline Surface Area $\left(\mathrm{m}^{2} / \mathrm{g}\right)$ & 390 & 528 & 462 & 379 & 189 \\
\hline $\mathrm{pH}$ & 12.7 & 12.3 & 11.7 & 10.9 & 10.4 \\
\hline
\end{tabular}

*The amount of filtrate and time (in minutes) until blowout is noted, respectively. 
reflection at $10.7 \AA$ in the air-dried state suggests a significant proportion of $\mathrm{I} S$.

\section{Saponite-Sepiolite /Lignite Fluids}

Fluid properties of $6 \%$ saponite-sepiolite/1\% lignite are listed in Figure 22 and Table 17. The addition of lignite reduces the viscosity of the saponite-sepiolite system at all temperatures (better than with bentonite fluids). Each of the fluids, however, displays a minor viscosity enhancement at various temperatures. For example, the fluid autoclaved at $500^{\circ} \mathrm{F}$ exhibits two viscosity enhancements; the first at $200^{\circ} \mathrm{F}$ and the second at $400^{\circ} \mathrm{F}$. The fluid becomes very thin after autoclaving at $600^{\circ} \mathrm{F}$, but displays a slight viscosity "hump" between 350 and $475^{\circ} \mathrm{F}$.

It is important to note that lignite does not improve the filtration control of the saponite-sepiolite system, contrary to the popular belief of practical field applications with conventional drilling fluids. In fact, there is a considerable increase in fluid loss from that of the pure saponite-sepiolite system. This is probably due to the evolution of $\mathrm{CO}_{2}$ gas from lignite.

Saponites in this fluid appear to have a non-uniform interlayer composition with a basal spacing that ranges from 14.8 to $13.1 \AA$. The basal spacing increases steadily to $15.0 \AA$ upon autoclaving at $600^{\circ} \mathrm{F}$. The sepiolite conversion rate is $30 \%$ at $300^{\circ} \mathrm{F}$, and is complete by $400^{\circ} \mathrm{F}$. The fluid $\mathrm{pH}$ remains slightly above neutral, and consequently, there are no major mineral reactions in these fluids.

\section{Saponite-Sepiolite / Lignosulfonate Fluids}

The addition of lignosulfonate to the saponite-sepiolite fluid at room temperature, and after autoclaving to $300^{2} \mathrm{~F}$, has a notable affect on the viscosity of these fluids (Figure 23 and Table 18). Both fluids are relatively thin and range between 4.5 and $11.0 \mathrm{cp}$. However, the fluids autoclaved at $400^{\circ} \mathrm{F}$ and above display somewhat different viscosity profiles (Figure 23). These fluids exhibit prominent viscosity anomalies, between 250 and $450^{\circ} \mathrm{F}$, whose magnitude increase with subsequent 


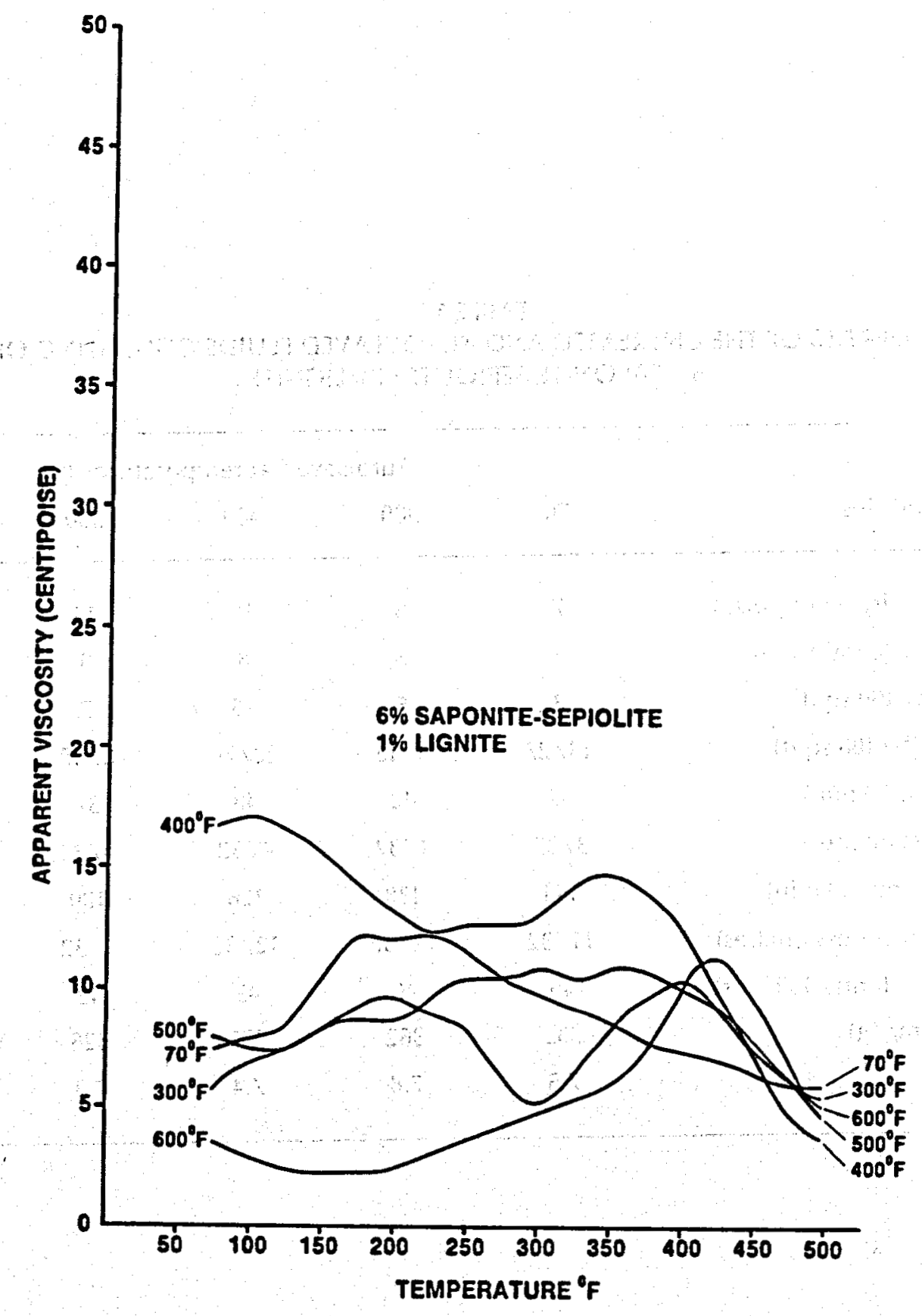

Figure 22 Viscosity profiles of $6 \%$ saponite-sepiolite $/ 7 \%$ lignite fluids autoclaved at various temperatures. 
TABLE 17

PROPERTIES OF THE UNTREATED AND AUTOCLAVED FLUIDS CONSISTING OF

6\% SAPONITE-SEPIOLITE/1\% LIGNITE

\begin{tabular}{lccccc}
\hline \multicolumn{1}{c}{ Autoclaved at temperatures ( ${ }^{\circ} \mathrm{F}$ ) } \\
\multicolumn{1}{c}{ Fluid Properties } & 70 & 300 & 400 & 500 & 600 \\
\hline Apparent Viscosity (centipoise) & 7 & 6 & 16 & 14 & 6 \\
Plastic Viscosity (centipoise) & 3 & 3 & 8 & 9 & 6 \\
Yield Point (lb/100 sq ft) & 8 & 5 & 16 & 7 & 1 \\
Gel Strength (lb/100 sq ft) & $13 / 27$ & $6 / 15$ & $22 / 70$ & $8 / 17$ & $.5 / 3$ \\
API Filtrate (ml/30 min) & 37 & 42 & 48 & 37 & 48 \\
Cake Thickness (inches) & $3 / 32$ & $4 / 32$ & $4 / 32$ & $4 / 32$ & $4 / 32$ \\
HP-HT Filtrate (ml/30 min) & 144 & 138 & 126 & 100 & 114 \\
HP-HT Cake Thickness (inches) & $11 / 32$ & $12 / 32$ & $12 / 32$ & $9 / 32$ & $9 / 32$ \\
CEC (milliequivalents/100 gms) & 49 & 46 & 43 & 42 & 38 \\
Surface Area (m ${ }^{2} / \mathrm{g}$ ) & 383 & 362 & 336 & 326 & 295 \\
pH & 7.5 & 7.8 & 7.4 & 7.3 & 7.8 \\
\hline
\end{tabular}




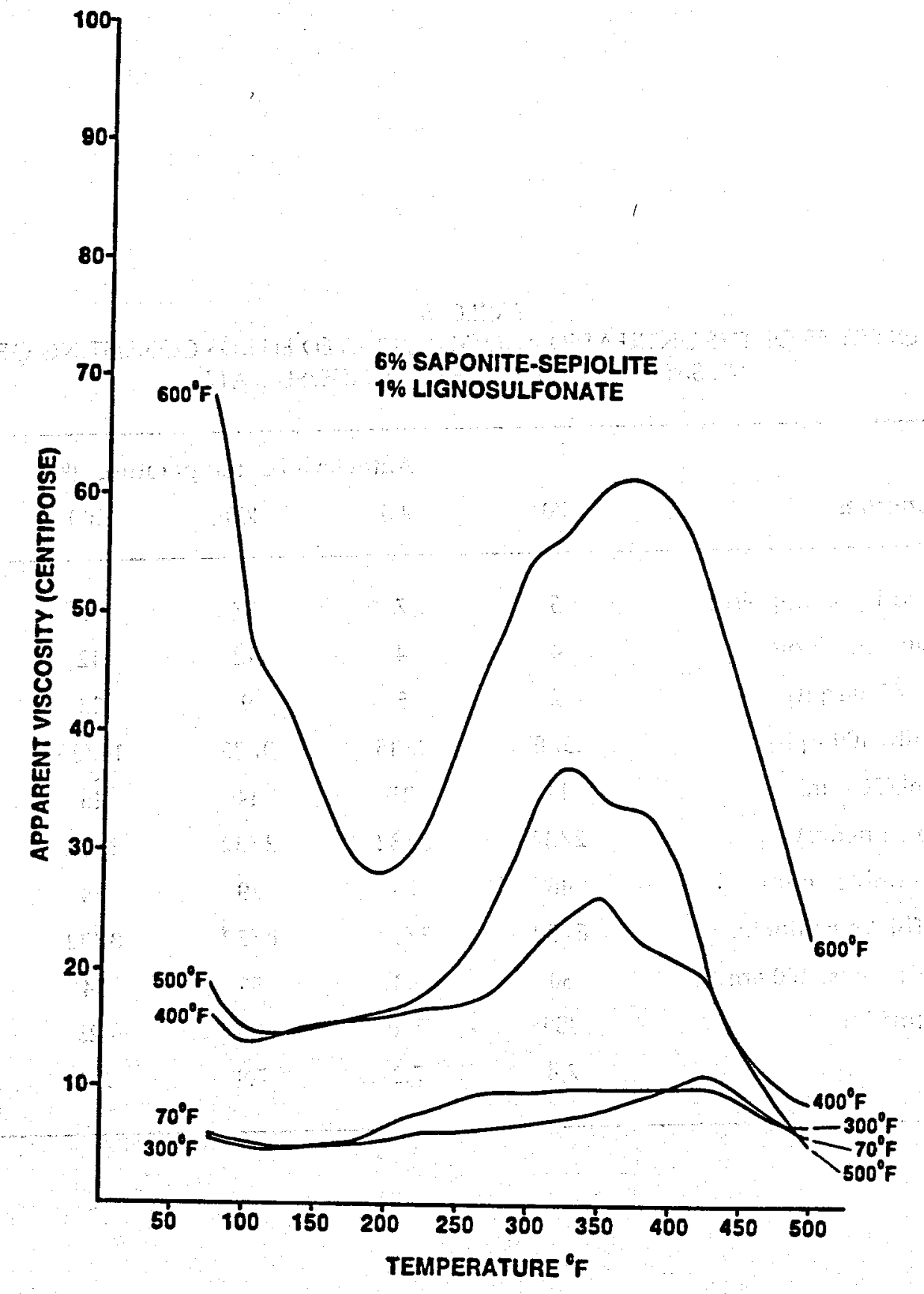

Figure 23. Viscosity profiles of $6 \%$ saponite-sepiolite $/ 1 \%$ lignosulfate fluids autoclaved at various temperatures. 
TABLE 18

PROPERTIES OF THE UNTREATED AND AUTOCLAVED FLUIDS CONSISTING OF $6 \%$ SAPONITE-SEPIOLITE/1\% LINGOSULFATE

\begin{tabular}{lccccc}
\hline \multicolumn{1}{c}{ Fluid Properties } & \multicolumn{5}{c}{ Autoclaved at temperatures ( ${ }^{\circ} \mathrm{F}$ ) } \\
& 70 & 300 & 400 & 500 & 600 \\
\hline Apparent Viscosity (centipoise) & 5 & 7 & 17 & 19 & 57 \\
Plastic Viscosity (centipoise) & 4 & 4 & 12 & 12 & 25 \\
Yield Point (lb/100 sq ft) & 2 & 5 & 9 & 13 & 63 \\
Gel Strength (lb/100 sq ft) & $.5 / 8$ & $3 / 15$ & $9 / 35$ & $14 / 35$ & $48 / 88$ \\
API Filtrate (ml/30 min) & 17 & 21 & 14 & 15 & 26 \\
Cake Thickness (inches) & $2 / 32$ & $3 / 32$ & $3 / 32$ & $3 / 32$ & $5 / 32$ \\
HP-HT Filtrate (ml/30 min) & 48 & 76 & 79 & 54 & 58 \\
HP-HT Cake Thickness (inches) & $6 / 32$ & $5 / 32$ & $8 / 32$ & $8 / 32$ & $9 / 32$ \\
CEC (milliequivalents/100 gms) & 50 & 43 & 55 & 54 & 52 \\
Surface Area (m ${ }^{2} / \mathrm{g}$ ) & 389 & 340 & 427 & 423 & 407 \\
pH & 7.4 & 7.3 & 7.4 & 7.6 & 7.6 \\
\hline
\end{tabular}


levels of autoclaving. Possible explanations for such viscosity maxima suggest the evolution of $\mathrm{CO}_{2}$ and $\mathrm{H}_{2} \mathrm{~S}$ gas as lignosulfonate decomposes at high temperatures, or possibly an increase in surface area as a result of a change in particle aggregation.

Table 18 summarizes other fluid properties. Apparent and plastic viscosity; yield point, and gel strength all increase with temperature. The lignosulfonate system has better filtration control than the lignite system, but it is interesting to note the increase in HP-HT filtrate from $48 \mathrm{ml} / 30 \mathrm{~min}$ at $70^{9} \mathrm{~F}$ to $76 \mathrm{ml} / 30 \mathrm{~min}$ at $300^{\circ} \mathrm{F}$. The fluid $\mathrm{pH}$ remains slightly above neutral.

Similar to the lignite system, lignosulfonate is also incorporated into the internal structure of saponite. The basal spacing of 14.9 to $13.2 \AA$ remains stable throughout the appropriate temperature range. The sepiolite conversion rate proceeds as follows; $0-5 \%$ at $300^{\circ} \mathrm{F}, 95 \%$ at $400^{\circ} \mathrm{F}$, and finally conversion is complete at and above $500^{\circ} \mathrm{F}$. No major mineral reactions take place in the presence of lignosulfonate at neutral $\mathrm{pH}$ values.

\section{Saponite-Sepiolite / NaClFluids}

Rheograms of the fluids containing $6 \%$ saponite- sepiolite $/ 1 \% \mathrm{NaCl}$ are displayed in Figure 24. The viscosity for the unautoclaved fluid at room temperature is higher than any other fluid in this system. Sepiolite provides good viscosity in both salt and fresh water at ambient temperature. Viscosity drops steadily with increasing temperature (as measured with the Fann $50 \mathrm{C}$ viscometer). The fluids autoclaved from $300-600^{2} \mathrm{~F}$ thin initially with temperature, experience a minor viscosity enhancement between 225 and $275^{\circ} \mathrm{F}$ and finally become very thin at $500^{\circ} \mathrm{F}$ (less than $5 \mathrm{cp}$ ).

Other rheological and wall-building properties are summarized in Table 19. The fluid autoclaved at $300^{\circ} \mathrm{F}$ has the highest API and HP.HT fluid loss values. Fluid loss values drop considerably above $300^{2} \mathrm{~F}$ (Table 19). The CEC evolves from 48 


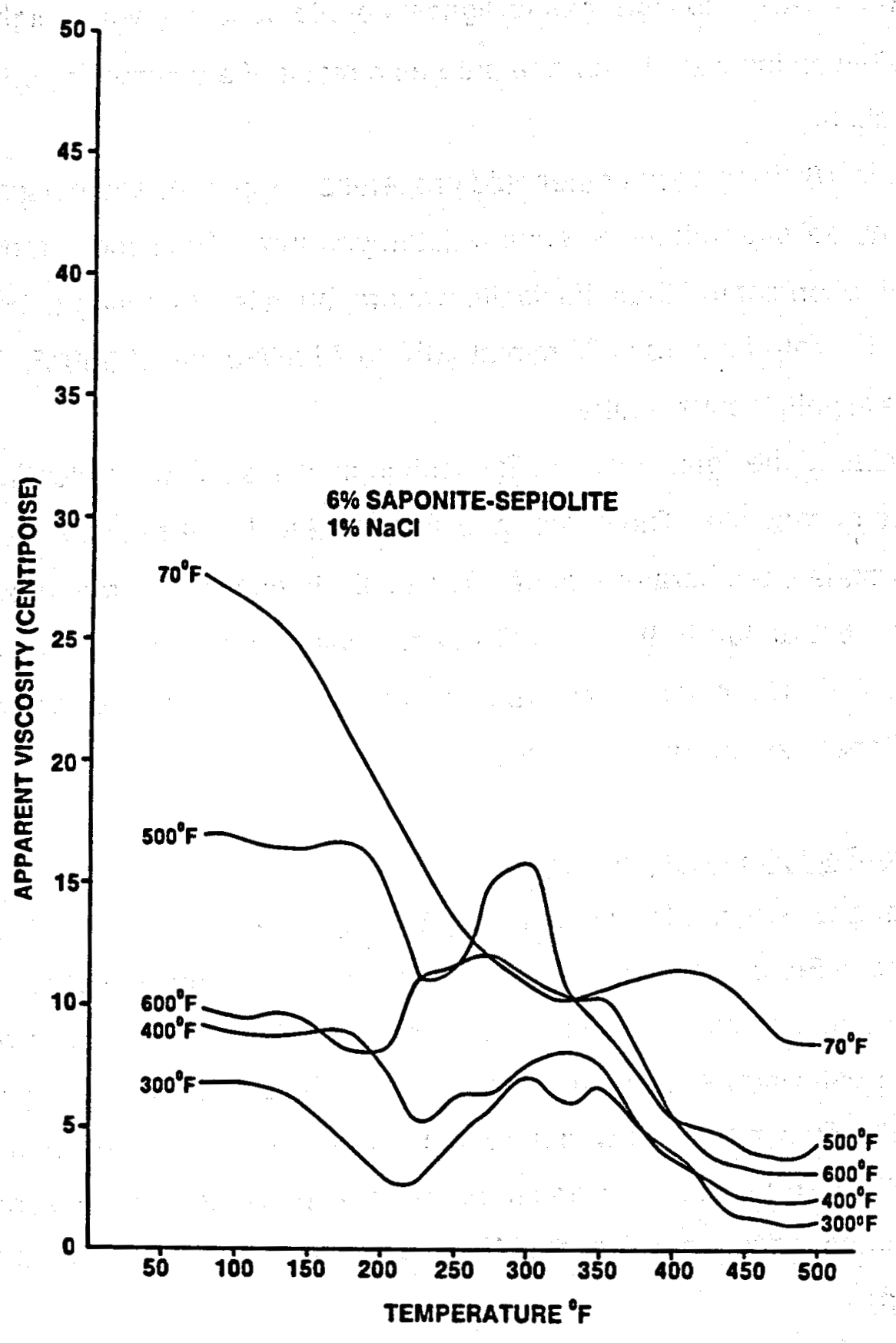

Figure 24. Viscosity profiles of $6 \%$ saponite-sepiolite $/ 1 \% \mathrm{NaCl}$ fluids autoclaved at various temperatures. 
TABLE 19

PROPERTIES OF THE UNTREATED AND AUTOCLAVED FLUIIDS CONSISTING OF $6 \%$ SAPONITE-SEPIOLITE $/ 7 \% \mathrm{NaCl}$

\begin{tabular}{|c|c|c|c|c|c|}
\hline \multirow[b]{2}{*}{ Fluid Properties } & \multirow[b]{2}{*}{70} & \multicolumn{3}{|c|}{ Autoclaved at temperatures $\left({ }^{\circ} \mathrm{F}\right)$} & \multirow[b]{2}{*}{600} \\
\hline & & 300 & 400 & 500 & \\
\hline & 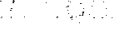 & & & & \\
\hline Apparent Viscosity (centipoise) & 21 & 8 & 10 & 15 & 8 \\
\hline Plastic Viscosity (centipoise) & 4 & 3 & 5 & 4 & 3 \\
\hline Yield Point (lb/100 sq ft) & 34 & 5 & 9 & 21 & 13 \\
\hline Gel Strength (lb/100 sq ft) & $21 / 30$ & $10 / 33$ & $9 / 24$ & $19 / 48$ & $10 / 28$ \\
\hline API filtrate $(\mathrm{ml} / 30 \mathrm{~min})$ & 40 & 70 & 36 & 31 & 40 \\
\hline Cake Thickness (inches) & $4 / 32$ & $8 / 32$ & $6 / 32$ & $4 / 32$ & $3 / 32$ \\
\hline HP-HT Filtrate $(\mathrm{ml} / 30 \mathrm{~min})$ & 158 & 194 & 124 & 92 & 104 \\
\hline HP-HT Cake Thickness (inches) & $8 / 32$ & $12 / 32$ & $11 / 32$ & $8 / 32$ & $8 / 32$ \\
\hline CEC (milliequivalents / $100 \mathrm{gms}$ ) & 48 & 52 & 57 & 66 & 54 \\
\hline Surface Area $\left(\mathrm{m}^{2} / \mathrm{g}\right)$ & 376 & 408 & 448 & 488 & 424 \\
\hline 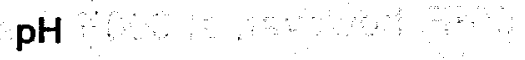 & 8.7 & 7.4 & 7.3 & 7.4 & 7.6 \\
\hline
\end{tabular}


meq $/ 100 \mathrm{~g}$ at $70^{\circ} \mathrm{F}$ to $62 \mathrm{meq} / 100 \mathrm{~g}$ at $500^{\circ} \mathrm{F}$, and then drops slightly at $600^{\circ} \mathrm{F}$.

There was no detectable change in relative sepiolite concentration after autoclaving the fluid to $300^{\circ} \mathrm{F}$; at $400^{\circ} \mathrm{F}$, however, conversion is complete. It is important to note that saponite has a $15.0 \AA$ basal spacing in the presence of the $\mathrm{Na}+$ ion, suggesting the presence of two molecular layers of water within the interlayer structure. The basal spacing contracts to $14.7 \AA$ in the air-dried state at $600^{\circ} \mathrm{F}$, and expands to $16.5 \AA$ upon glycolation. Free $\mathrm{Ca}^{2}+$ in solution readily precipitates as calcite in the unautoclaved fluid and fluids autoclaved at 400 and $500^{\circ} \mathrm{F}$.

\section{Saponite-Sepiolite / $\mathrm{Na}_{2} \mathrm{CO}_{3}$ Fluids}

The rheological properties of $6 \%$ saponite-sepiolite $/ 1 \% \mathrm{Na} 2 \mathrm{CO} 3$ are given in Figure 25a and Table 20. The viscosity profiles of the unautoclaved and fluids autoclaved from 300 to $500^{\circ} \mathrm{F}$ bear striking similarity (Figure 25a). The initial viscosity of these fluids range from 13 to $23 \mathrm{cp}$ at room temperature and decrease uniformly with temperature to a final viscosity of 5.6 to $7.6 \mathrm{cp}$ at $500^{\circ} \mathrm{F}$. The fluid autoclaved at $600^{\circ} \mathrm{F}$, however, demonstrates a marked difference in viscosity at room temperature. It has an initial viscosity of $76.3 \mathrm{cp}$, but drops rather abruptly to $8.4 \mathrm{cp}$ at $500^{\circ} \mathrm{F}$.

Other fluid properties are listed in Table 20. API and HP-HT fluid loss values improve with subsequent levels of autoclaving up to $500^{\circ} \mathrm{F}$; however, at $600^{\circ} \mathrm{F}$ there is a dramatic increase in fluid loss. The above variations in fluid properties reflect two sets of different mineral reactions at high temperatures:

a) sepiolite begins to convert to a smectite (stevensite) at $300^{\circ} \mathrm{F}\left(149^{\circ} \mathrm{C}\right.$ ) and this reaction is fully complete at $500^{\circ} \mathrm{F}\left(260^{\circ} \mathrm{C}\right)$. The new smectites in the fluid have a thin flaky morphology which is similar to that illustrated in Figure $13 \mathrm{c}$ and they increase the viscosity and improve the filtration losses; 


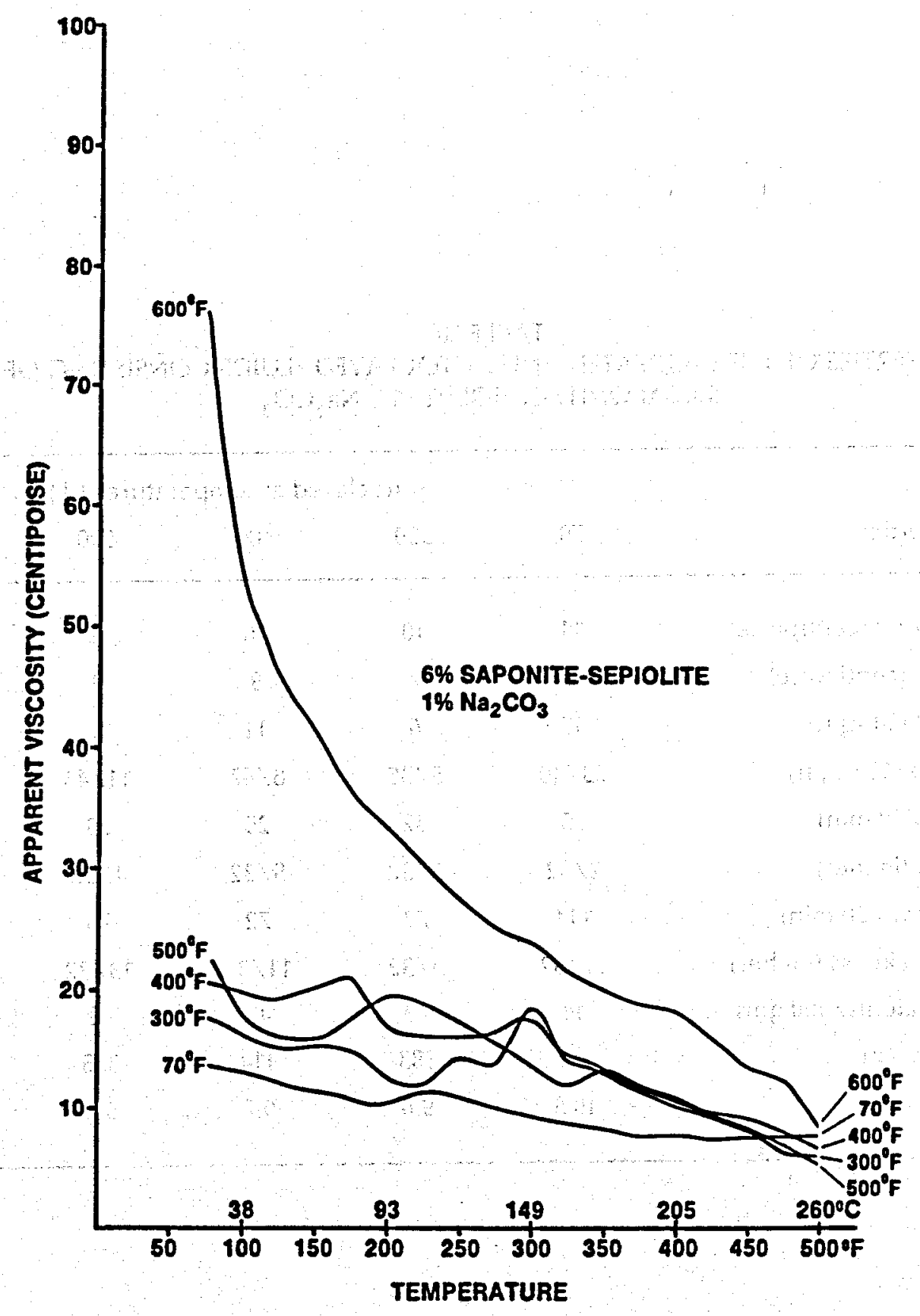

Figure $25 \mathrm{a}$. Viscosity profiles of $6 \%$ saponite-sepiolite $/ 1 \% \mathrm{Na}_{2} \mathrm{CO}_{3}$ fluids autoclaved at various temperatures. 
TABLE 20

PROPERTIES OF THE UNTREATED AND AUTOCLAVED FLUIDS CONSISTING OF

$6 \%$ SAPONITE-SEPIOLITE $/ 1 \% \mathrm{Na}_{2} \mathrm{CO}_{3}$

\begin{tabular}{|c|c|c|c|c|c|}
\hline \multirow[b]{2}{*}{ Fluid Properties } & \multicolumn{5}{|c|}{ Autoclaved at temperatures ( $\left.{ }^{\circ} \mathrm{F}\right)$} \\
\hline & 70 & 300 & 400 & 500 & 600 \\
\hline Apparent Viscosity (centipoise) & 11 & 10 & 16 & 19 & 64 \\
\hline Plastic Viscosity (centipoise) & 2 & 7 & 9 & 9 & 18 \\
\hline Yield Point (lb/100 sq ft) & 17 & 6 & 11 & 17 & 92 \\
\hline Gel Strength (lb/100 sq ft) & $23 / 40$ & $5 / 35$ & $8 / 47$ & $11 / 43$ & $36 / 36$ \\
\hline API Filtrate $(\mathrm{ml} / 30 \mathrm{~min})$ & 30 & 32 & 25 & 23 & 52 \\
\hline Cake Thickness (inches) & $2 / 32$ & $5 / 32$ & $5 / 32$ & $4 / 32$ & $\cdots$ \\
\hline HP-HT filtrate $(\mathrm{ml} / 30 \mathrm{~min})$ & 114 & 72 & 72 & 78 & 156 \\
\hline HP-HT Cake Thickness (inches) & $11 / 32$ & $9 / 32$ & $11 / 32$ & $13 / 32$ & $17 / 32$ \\
\hline CEC (milliequivalents/100 gms) & 44 & 49 & 43 & 43 & 28 \\
\hline Surface Area $\left(\mathrm{m}^{2} / \mathrm{g}\right)$ & 345 & 383 & 414 & 335 & 216 \\
\hline $\mathrm{pH}$ & 10.5 & 9.8 & 9.7 & 9.6 & 9.8 \\
\hline
\end{tabular}




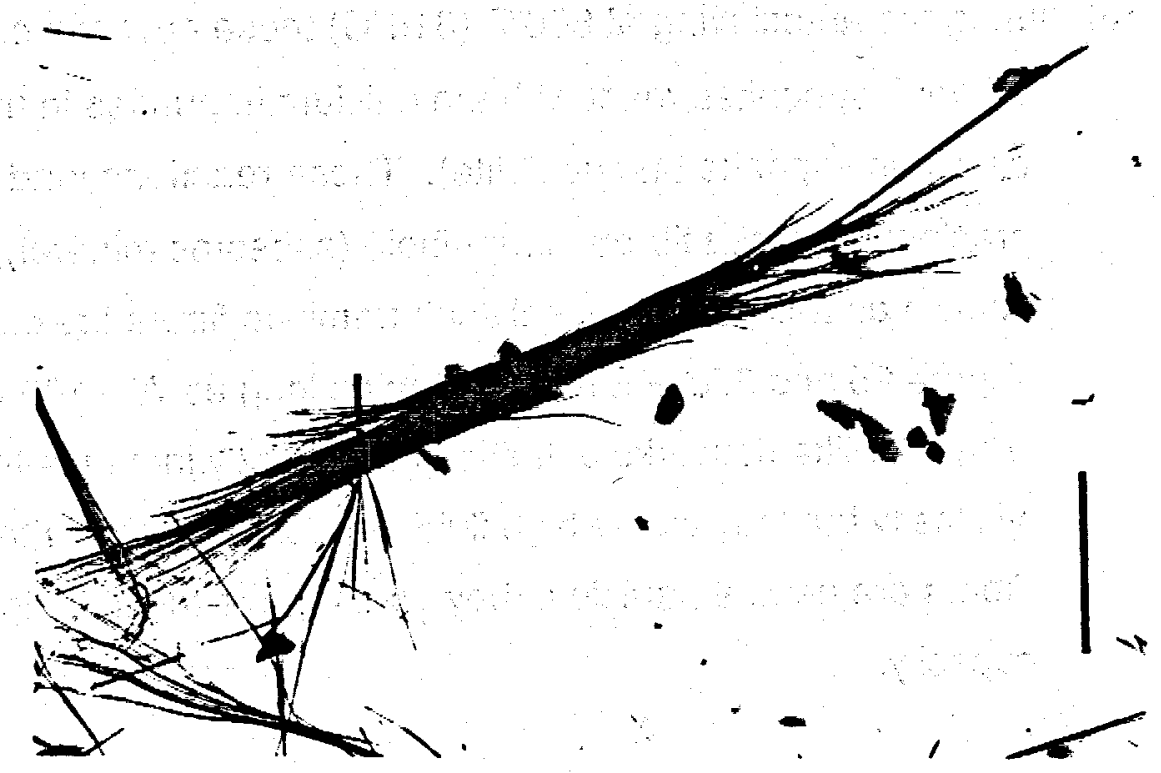

Figure 25b. Growth of tremolite fibers (an asbestos variety) in the sepiolitesaponite $/ \mathrm{Na}_{2} \mathrm{Cl}_{3}$ fluid; scale: 10 microns.

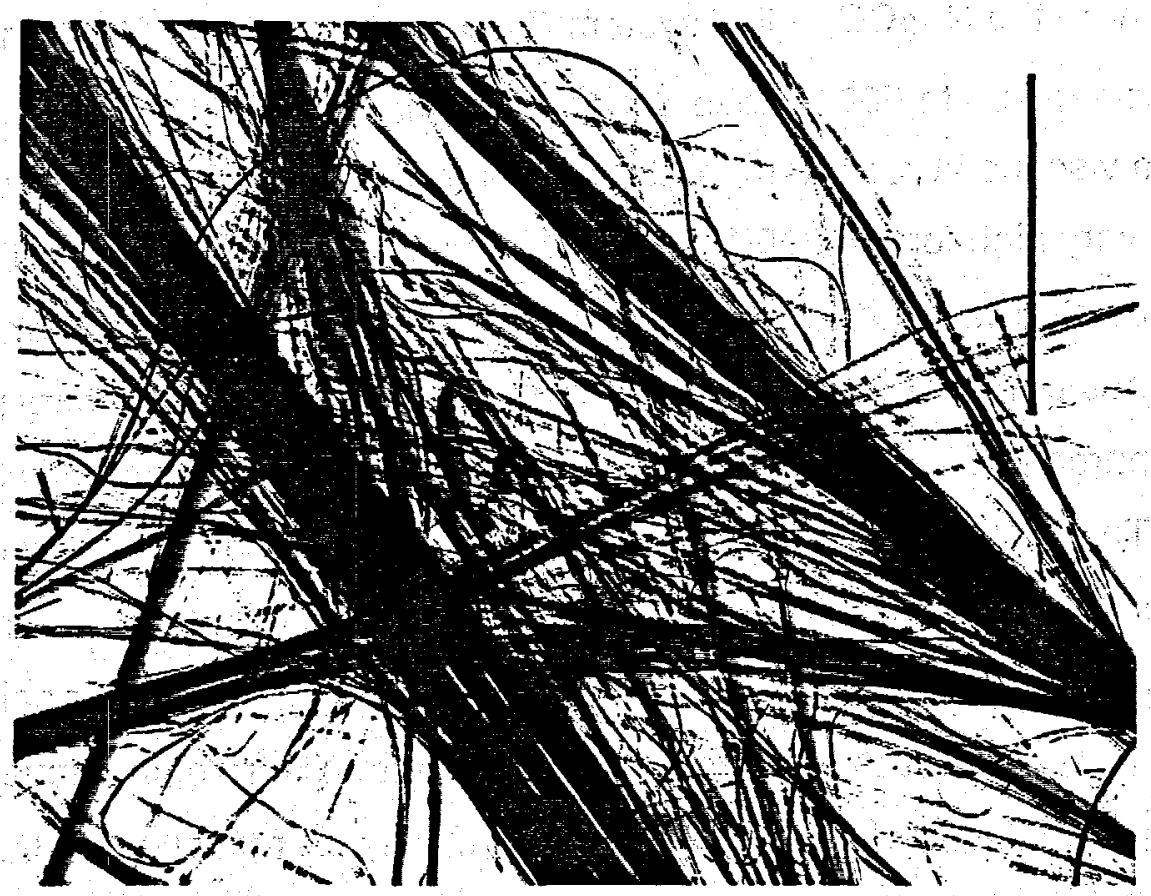

Figure 25c. A close view of tremolite fibers in the sepiolite-saponite $/ \mathrm{Na}_{2} \mathrm{Cl}_{3}$ fluid; scale: 0.5 microns. 
b) during the autoclaving at $600^{\circ} \mathrm{F}\left(316^{\circ} \mathrm{C}\right)$ these new smectites and the original saponites react with the calcium impurities in the clays (i.e. calcite in saponite and sepiolite). These reactions lead to the precipitations of a fibrous amphibole (asbestos mineral), which is known as tremolite. Typical such tremolite fibers are displayed in Figure 25 and $25 \mathrm{c}$ and they can be as long as $70-100$ microns. The web-like networks of these fibers greatly increase the fluid viscosity but they cause high fluid losses. Since the tremolite fibers are neutral particles, they do not have much cation exchange capacity.

\section{Saponite-Sepiolite / NaOH Fluids}

The viscosity profiles of $6 \%$ saponite-sepiolite $/ 1 \% \mathrm{NaOH}$ fluids are remarkably similar to the $\mathrm{Na}_{2} \mathrm{CO}_{3}$ fluid system (Figure 26 and Table 21). Once again, the fluids autoclaved up to $500^{\circ} \mathrm{F}$ have rather stable viscosities. The $600^{\circ} \mathrm{F}$ fluid is significantly more viscous at room temperature. Furthermore, yield point and gel strengths are also very high for the $600^{\circ} \mathrm{F}$ fluid. Filtration control improves from 70 to $400^{\circ} \mathrm{F}$ (associated with the conversion of sepiolite to smectite); However, the precipitation of fiberous tremolite at high temperatures ( 500 and $600^{\circ} \mathrm{F}$ ) (27 meq/100 grams) compared to $70 \mathrm{meq} / 100 \mathrm{grams}$ at $400^{\circ} \mathrm{F}$ is in direct agreement with the above data.

The highly alkaline environment in the presence of $\mathrm{NaOH}$ promotes the conversion of sepiolite to smectite up to $400^{\circ} \mathrm{F}$. In fact, the conversion rate is complete upon autoclaving at $300^{\circ} \mathrm{F}$. The basal spacing of saponite ranges from 13.2 to $14.9 \AA$, which indicates a heterogenous mixture of interlayer cations with one and two molecular layers of water, respectively. A reflection at $32.7 \AA$ verifies the co-existence of different interlayer cations. The precipitations of tremolite and some albite (Na-plagioclase) are the main mineral reaction in these fluids at high 
temperatures at the expense of smectite. The tremolite fibers increases greatly the fluid viscosity upon autoclaving at $600^{2} \mathrm{~F}$, but it proves to be detrimental to the filtration control of the fluid. 


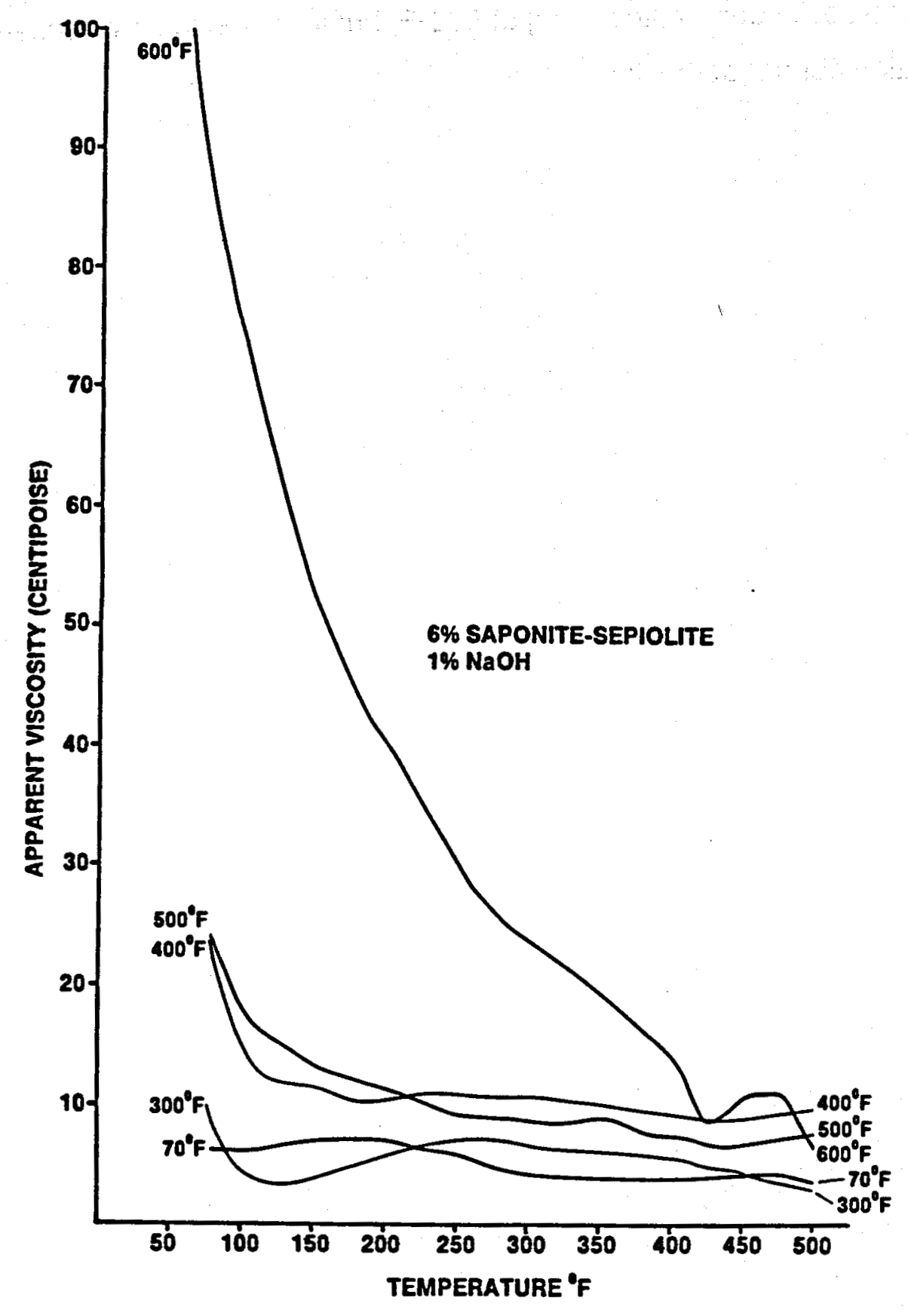

Figure 26. Viscosity profiles of $6 \%$ saponite-sepiolite $/ 1 \% \mathrm{NaOH}$ fluids autoclaved at various temperatures. 


\begin{tabular}{|c|c|c|c|c|c|}
\hline \multirow[b]{2}{*}{ Fluid Properties } & \multicolumn{5}{|c|}{ Autoclaved at temperatures $\left({ }^{\circ} \mathrm{F}\right)$} \\
\hline & 70 & 300 & 400 & 500 & 600 \\
\hline Apparent Viscosity (centipoise) & 6 & 10 & 21 & 24 & 77 \\
\hline Plastic Viscosity (centipoise) & 2 & 4 & 9 & 11 & 22 \\
\hline Yield Point (lb/100 sq ft) & 8 & 12 & 24 & 26 & 109 \\
\hline Gel Strength (lb/100 sq ft) & $7 / 10$ & $11 / 21$ & $11 / 28$ & $11 / 15$ & $50 / 50$ \\
\hline API Filtrate (ml/30 $\mathrm{min})$ & 47 & 37 & 38 & 42 & 47 \\
\hline Cake Thickness (inches) & $3 / 32$ & $4 / 32$ & $4 / 32$ & $4 / 32$ & --- \\
\hline HP-HT Filtrate $(\mathrm{ml} / 30 \mathrm{~min})^{*}$ & $220 / 24$ & 108 & 104 & 150 & $142 / 8$ \\
\hline HP-HT Cake Thickness (inches) & $11 / 32$ & $9 / 32$ & $10 / 32$ & $12 / 32$ & $\cdots$ \\
\hline CEC (milliequivalents $/ 100 \mathrm{gms}$ ) & 49 & 70 & 70 & 43 & 27 \\
\hline Surface Area $\left(\mathrm{m}^{2} / \mathrm{g}\right)$ & 385 & 547 & 545 & 335 & 211 \\
\hline $\mathrm{pH}$ & 12.8 & 12.6 & 12.3 & 11.5 & 10.8 \\
\hline
\end{tabular}

* The amount of filtrate and time (in minutes) until blowout is noted, respectively. 


\section{NEW FLUID FORMULATIONS}

A thorough account of the high temperature reactions of saponite and saponite/sepiolite fluids has provided a base upon which new fluids can be formulated. Having concluded that a blend of saponite/sepiolite would be the best primary viscosifier for water-based muds (considering salt make-up of waters), a series of new muds have been formulated and tested at high temperatures and pressures. These muds are referred to as Fluids A-E, and are formulated as follows:

Fluid A: $\quad 25 \mathrm{lbs} / \mathrm{bbl}$ Saponite-Sepiolite $5 \mathrm{lbs} / \mathrm{bbl}$ High molecular weight polymer $1 \mathrm{lbs} / \mathrm{bbl}$ Low molecular weight polymer

Fluid B: $\quad 25 \mathrm{lbs} / \mathrm{bb}$ Saponite-Sepiolite $5 \mathrm{lbs} / \mathrm{bbl}$ High molecular weight polymer $1 \mathrm{lbs} / \mathrm{bbl}$ Low molecular weight polymer $12 \mathrm{lbs} / \mathrm{gal}$ (weighted with barite)

Fluid C: $\quad 25 \mathrm{lbs} / \mathrm{bbl}$ Saponite-Sepiolite $5 \mathrm{lbs} / \mathrm{bbl}$ High molecular weight polymer $1 \mathrm{lbs} / \mathrm{bb}$ Low molecular weight polymer $14 \mathrm{lbs} / \mathrm{gal}$ (weighted with barite)

Fluid D: $\quad 25$ lbs/bbl Saponite-Sepiolite $5 \mathrm{lbs} / \mathrm{bbl}$ High molecular weight polymer $2 \mathrm{lbs} / \mathrm{bbl}$ Low molecular weight polymer $14 \mathrm{lbs} / \mathrm{gal}$ (weighted with barite)

Fluid E: $\quad 25 \mathrm{lbs} / \mathrm{bbl}$ Saponite-Sepiolite $5 \mathrm{lbs} / \mathrm{bbl}$ High molecular weight polymer $3 \mathrm{lbs} / \mathrm{bbl}$ Low molecular weight polymer $16 \mathrm{lbs} / \mathrm{bbl}$ (weighted with barite)

\section{Fluid A}

The rheological properties of Fluid A are given in Figure 27 and Table 22. This fluid formulation, for the most part, eliminates the anomalous viscosity 


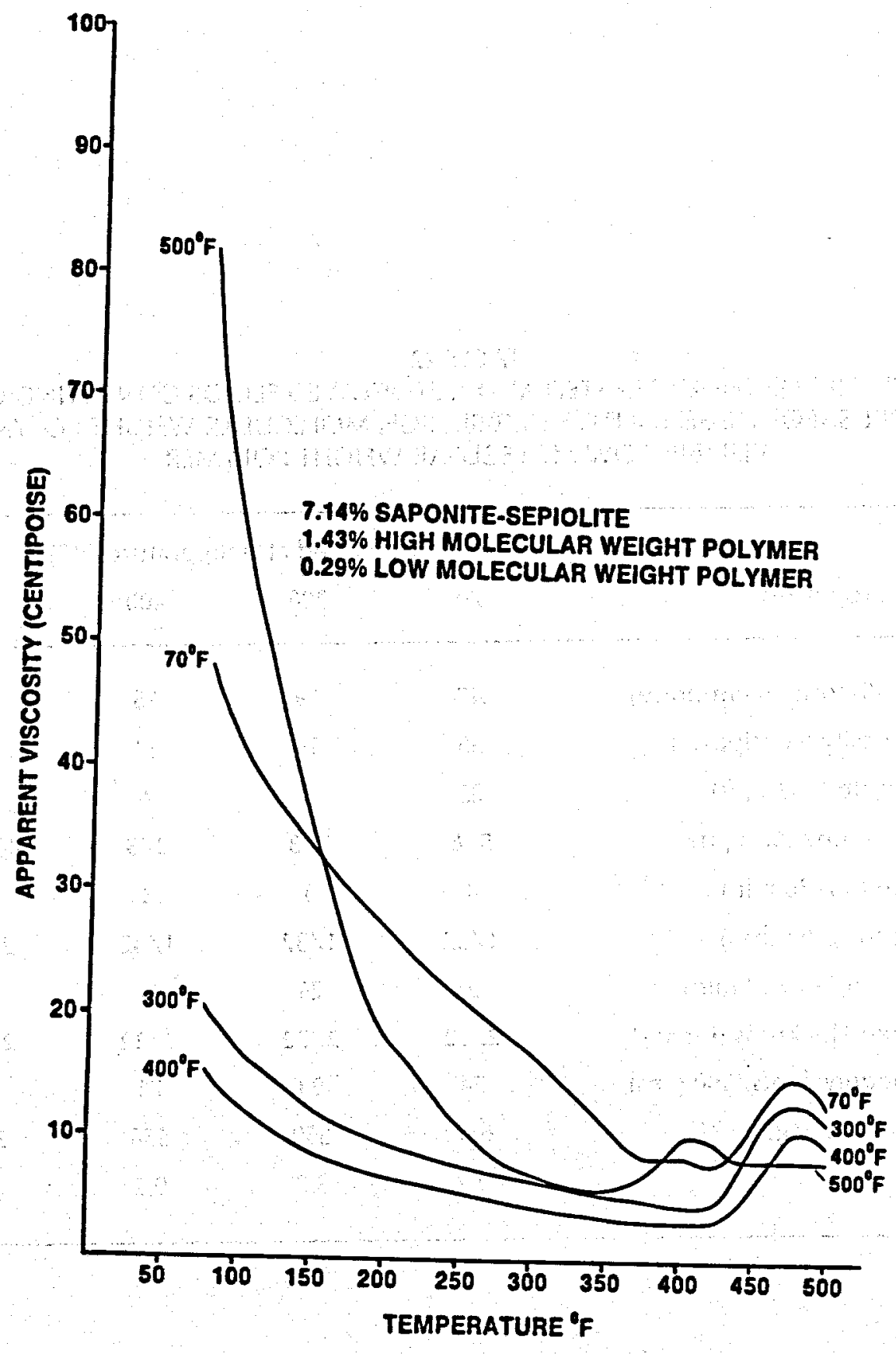

Figure 27. Viscosity profiles of Fluid A after autoclaving at various temperatures. 
TABLE 22

PROPERTIES OF THE UNTREATED AND AUTOCLAVED FLUIDS CONSISTING OF 25 LB/BBL SAPONITE-SEPIOLITE, 5 LB/BBL HIGH MOLECULAR WEIGHT POLYMER, 1 LB/BBL LOW MOLECULAR WEIGHT POLYMER

\begin{tabular}{lccccc}
\hline \multicolumn{1}{c}{ Fluid Properties } & \multicolumn{3}{c}{ Autoclaved at temperatures $\left({ }^{\circ} \mathrm{F}\right)$} \\
& 70 & 300 & 400 & 500 \\
\hline Apparent Viscosity (centipoise) & 47 & 19 & 16 & 98 \\
Plastic Viscosity (centipoise) & 35 & 16 & 14 & 26 \\
Yield Point (lb/100 sq ft) & 23 & 6 & 4 & 144 \\
Gel Strength (lb/100 sq ft) & $5 / 8$ & $2 / 3$ & $2 / 3$ & $46 / 58$ \\
API Filtrate (ml/30 min) & 4 & 3 & 3 & 6 \\
Cake Thickness (inches) & $1 / 32$ & $1 / 32$ & $1 / 32$ & $2 / 32$ \\
HP-HT Filtrate (ml/30 min) & 20 & 26 & 22 & 20 \\
HP-HT Cake Thickness (inches) & $2 / 32$ & $2 / 32$ & $2 / 32$ & $2 / 32$ \\
CEC (milliequivalents/100 gms) & 84 & 83 & 71 & 92 \\
Surface Area (m ${ }^{2} / \mathrm{g}$ ) & 657 & 650 & 556 & 720 \\
pH & 9.2 & 9.2 & 9.2 & 8.4 \\
\hline
\end{tabular}


enhancement present in the pure saponite-sepiolite fluids. As expected, the unautoclaved fluid is more viscous at room temperature than the saponite-sepiolite fluid. However, this fluid thins with increasing temperature, as measured with the Fann $50 \mathrm{C}$. Subsequent levels of autoclaving to 300 and $400^{\circ} \mathrm{F}$ reduce the fluid viscosities. The fluid autoclaved at $500^{\circ} \mathrm{F}$ exhibits a significant increase in fluid viscosity. Filtration control of this fluid is very good. In fact, these values (API and HP-HT) are well within the realm of operational limits.

Saponite and sepiolite reflections superimpose in the air-dried state and separate into their respective 16.3 and $12.1 \AA$ basal spacings upon glycolation. The sepiolite conversion was negligible at 300 and $400^{\circ} \mathrm{F}$; the conversion was, however, complete at $500^{\circ} \mathrm{F}$. It appears that the polymers begin to decompose above $400^{\circ} \mathrm{F}$, but, they remain intact until the sepiolite to smectite conversion is complete. This was confirmed by the change in fluid $\mathrm{pH}$ from 400 to $500^{\circ} \mathrm{F}$. There are no mineral reactions in these fluids.

\section{Fluid B}

Fluid A was weighted to $12 \mathrm{lbs} / \mathrm{gal}$ by adding the appropriate barite. As expected from the increase in surface area, the viscosity of the fluids has increased proportionally (with exception of the fluid autoclaved at $500^{\circ} \mathrm{F}$ ). As seen in Figure 28, these fluids experience a viscosity maximum above $350^{\circ} \mathrm{F}$. Filtration control has improved slightly over Fluid $\mathrm{A}$, and fluid $\mathrm{pH}$ exhibits the same pattern as the previous system (Table 23).

According to conventional field standards, yield point is slightly higher than operational limits. Therefore, $10 \%$ deionized water by volumn was added to this fluid system. Once again, the rheological properties of Fluid B were measured with the Fann 35A. In all cases, rheological measurements can be adjusted in order to obtain acceptable values. Furthermore, the addition of water had a rather favorable effect upon filtration control. As seen 


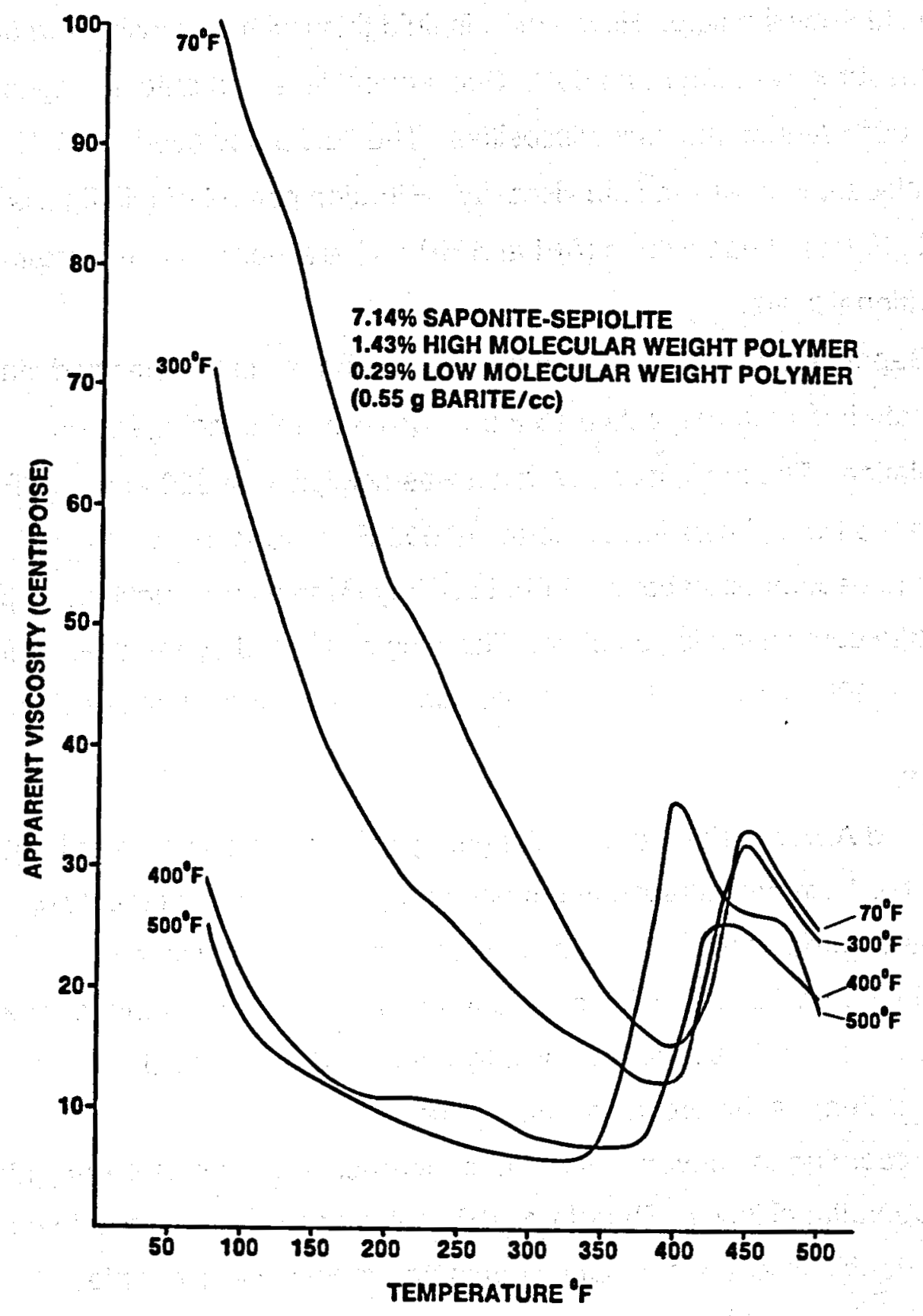

Figure 28. Viscosity profiles of Fluid B after autoclaving at various temperatures. 
TABLE 23

PROPERTIES OF THE UNTREATED AND AUTOCLAVED FLUIDS CONSISTING OF 25 LB/BBL SAPONITE-SEPIOLITE, 5 LB/BBL HIGH MOLECULAR WEIGHT POLYMER, 1 LB/BBL LOW MOLECULAR WEIGHT POLYMER, 12\#/GAL

\begin{tabular}{|c|c|c|c|c|}
\hline \multirow{2}{*}{ Fluid Properties } & \multicolumn{4}{|c|}{ Autoclaved at temperatures $\left({ }^{\circ} \mathrm{F}\right)$} \\
\hline & 70 & 300 & 400 & 500 \\
\hline Apparent Viscosity (centipoise) & 87 & 64 & 30 & 40 \\
\hline Plastic Viscosity (centipoise) & 64 & 48 & 25 & 29 \\
\hline Yield Point (lb/100 sq ft) & 46 & 32 & 10 & 22 \\
\hline Gel Strength (lb/100 sq ft) & $11 / 20$ & $8 / 11$ & $4 / 6$ & $5 / 12$ \\
\hline API Filtrate $(\mathrm{ml} / 30 \mathrm{~min})$ & 2 & 1 & 2 & 3 \\
\hline Cake Thickness (inches) & $1 / 32$ & $1 / 32$ & $1 / 32$ & $1 / 32$ \\
\hline HP-HT Filtrate $(\mathrm{ml} / 30 \mathrm{~min})$ & 18 & 16 & 18 & 22 \\
\hline HP-HT Cake Thickness (inches) & $3 / 32$ & $3 / 32$ & $3 / 32$ & $3 / 32$ \\
\hline $\mathrm{pH}$ & 9.1 & 9.0 & 9.2 & 8.7 \\
\hline
\end{tabular}


in the fluid autoclaved at $500^{\circ} \mathrm{F}$, for example, fluid loss dropped from $22 \mathrm{ml} / 30$ $\min$ to $18 \mathrm{ml} / 30 \mathrm{~min}$, suggesting an increase in dispersion.

$X$-ray diffraction analysis and CEC were omitted in the weighted fluids due to the high concentration of barite.

\section{Fluid C}

The viscosity profiles of Fluid $C$ are illustrated in Figure 29. These fluids exhibit a decrease in viscosity with subsequent levels of autoclaving. Similar to Fluid B,these fluids experience a viscosity enhancement above $350^{9} \mathrm{~F}$, and yield point is also in excess of operational limits (Table 24). Therefore, $15 \%$ water by volume was added to the fluids. Once again, the rheological properties can be adjusted to obtain operational values. The addition of water seems to increase dispersion. This can be confirmed by a decrease in filtrate from $24 \mathrm{ml} / 30 \mathrm{~min}$ to $18 \mathrm{ml} / 30 \mathrm{~min}$ in the fluid autoclaved at $500^{\circ} \mathrm{F}$.

\section{Fluid D}

Low molecular weight polymer was increased in order to remedy the high yield point in Fluid $C$. Consequently, these fluids exhibit a subsequent decrease in yield point, but they are still relatively high (Table 25). Therefore, $15 \%$ water was also added to these fluids. Similar to the previous fluid formulations, yield point is lowered without a loss in filtration control. The viscosity profiles of these fluids are given in Figure 30.

\section{Fluid E}

Finally, the fluid formulation was weighted to $16 \mathrm{lbs} / \mathrm{gal}$ by adding the appropriate barite. As expected from an increase in solids content per unit volume of water, the rheological properties have increased accordingly (Figure 31 and Table 26). These properties may be adjusted to the acceptable field limits by controlling the concentration of saponite-sepiolite. The fluid loss control of these fluids is extremely good (Table 26). 


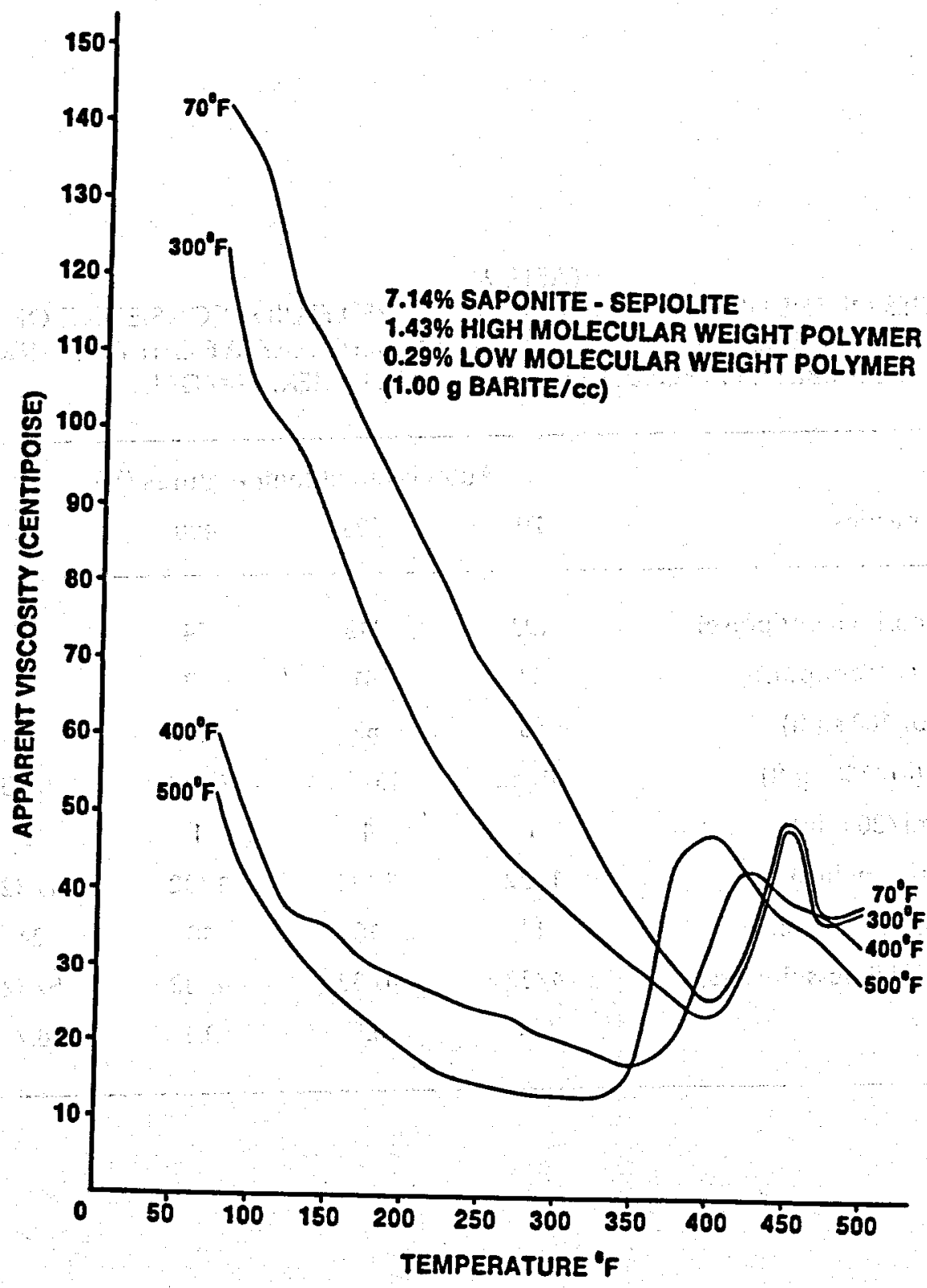

Figure 29. Viscosity profiles of Fluid $C$ after autoclaving at various temperatures. 
TABLE 24

PROPERTIES OF THE UNTREATED AND AUTOCLAVED FLUIDS CONSISTING OF 25 LB/BBL SAPONITE-SEPIOLITE, 5 LB/BBL HIGH MOLECULAR WEIGHT POLYMER, 1 LB/BBL LOW MOLECULAR WEIGHT POLYMER, 14\#/GAL

\begin{tabular}{lcccc}
\hline \multicolumn{1}{c}{ Fluid Properties } & \multicolumn{4}{c}{ Autoclaved at temperatures ( $\mathrm{F}$ ) } \\
& 70 & 300 & 400 & 500 \\
\hline Apparent Viscosity (centipoise) & 123 & 113 & 54 & 57 \\
Plastic Viscosity (centipoise) & 83 & 81 & 42 & 40 \\
Yield Point (lb/100 sq ft) & 80 & 63 & 23 & 34 \\
Gel Strength (lb/100 sq ft) & $20 / 42$ & $15 / 22$ & $6 / 12$ & $8 / 23$ \\
API Filtrate (ml/30 min) & 1 & 1 & 1 & 2 \\
Cake Thickness (inches) & $1 / 32$ & $1 / 32$ & $1 / 32$ & $1 / 32$ \\
HP-HT Filtrate (ml/30 min) & 14 & 16 & 18 & 24 \\
HP-HT Cake Thickness (inches) & $4 / 32$ & $4 / 32$ & $4 / 32$ & $5 / 32$ \\
pH & 9.3 & 8.8 & 9.1 & 8.7 \\
\hline
\end{tabular}




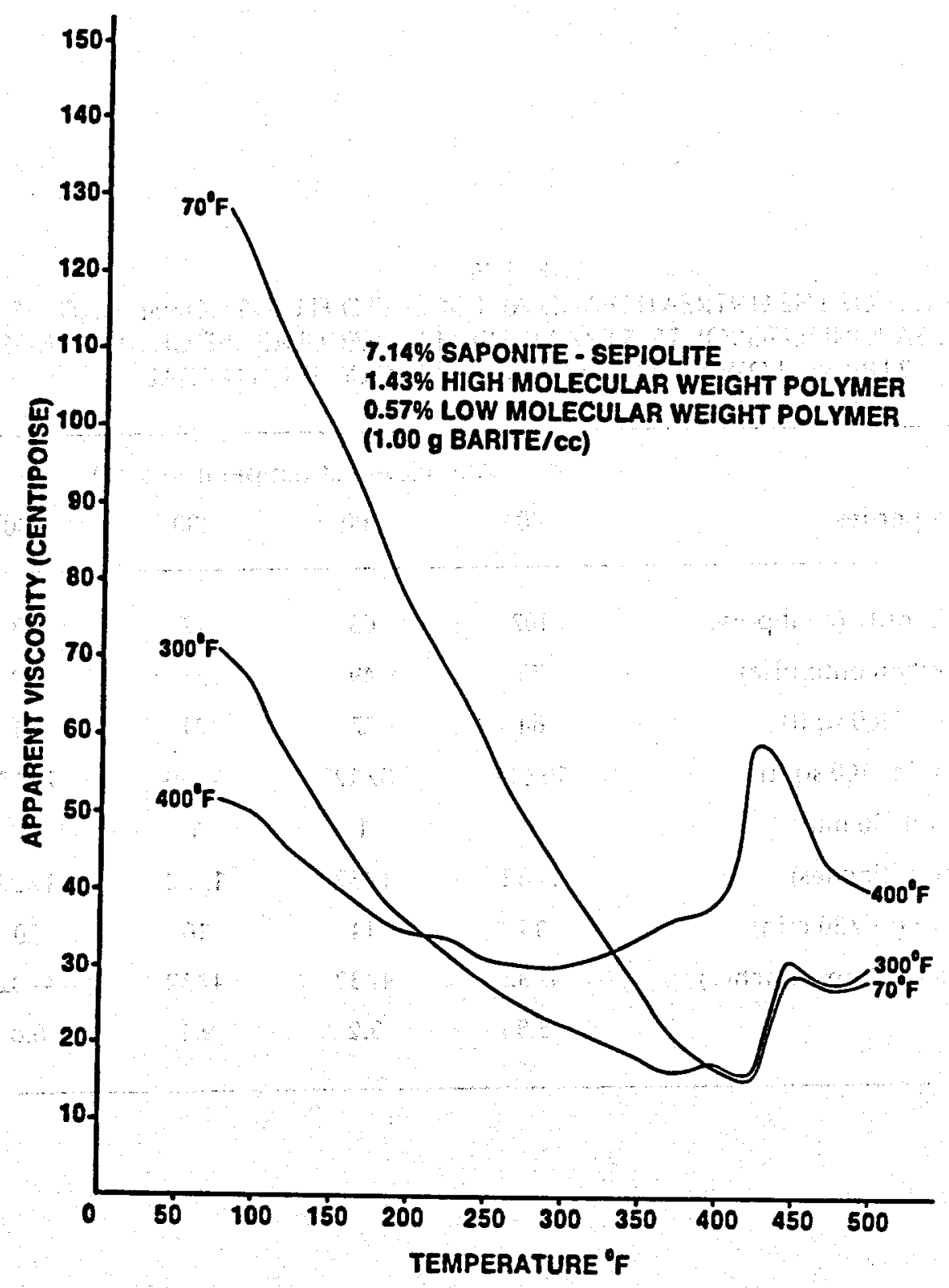

Figure 30. Viscosity profiles of Fluid D after autoclaving at various temperatures. 
TABLE 25

PROPERTIES OF THE UNTREATED AND AUTOCLAVED FLUIDS CONSISTING OF 25 LB/BBL SAPONITE-SEPIOLITE, 5 LB/BBL HIGH MOLECULAR WEIGHT POLYMER, 2 LB/BBL LOW MOLECULAR WEIGHT POLYMER, 14\#/GAL

\begin{tabular}{lcccc}
\hline \multicolumn{4}{c}{ Fluid Properties } & \multicolumn{4}{c}{ Autoclaved at temperatures ( ${ }^{\circ}$ ) } & \\
& 70 & 300 & 400 & 500 \\
\hline Apparent Viscosity (centipoise) & 107 & 63 & 47 & 53 \\
Plastic Viscosity (centipoise) & 75 & 49 & 36 & 32 \\
Yield Point (lb/100 sq ft) & 64 & 27 & 21 & 41 \\
Gel Strength (lb/100 sq ft) & $16 / 34$ & $8 / 12$ & $6 / 10$ & $7 / 15$ \\
API Filtrate (ml/30 min) & 1 & 1 & 1 & 3 \\
Cake Thickness (inches) & $1 / 32$ & $1 / 32$ & $1 / 32$ & $1 / 32$ \\
HP-HT Filtrate (ml/30 min) & 14 & 14 & 16 & 20 \\
HP-HT Cake Thickness (inches) & $4 / 32$ & $4 / 32$ & $4 / 32$ & $4 / 32$ \\
pH & 8.8 & 9.2 & 9.1 & 8.8 \\
& & & & \\
\hline
\end{tabular}




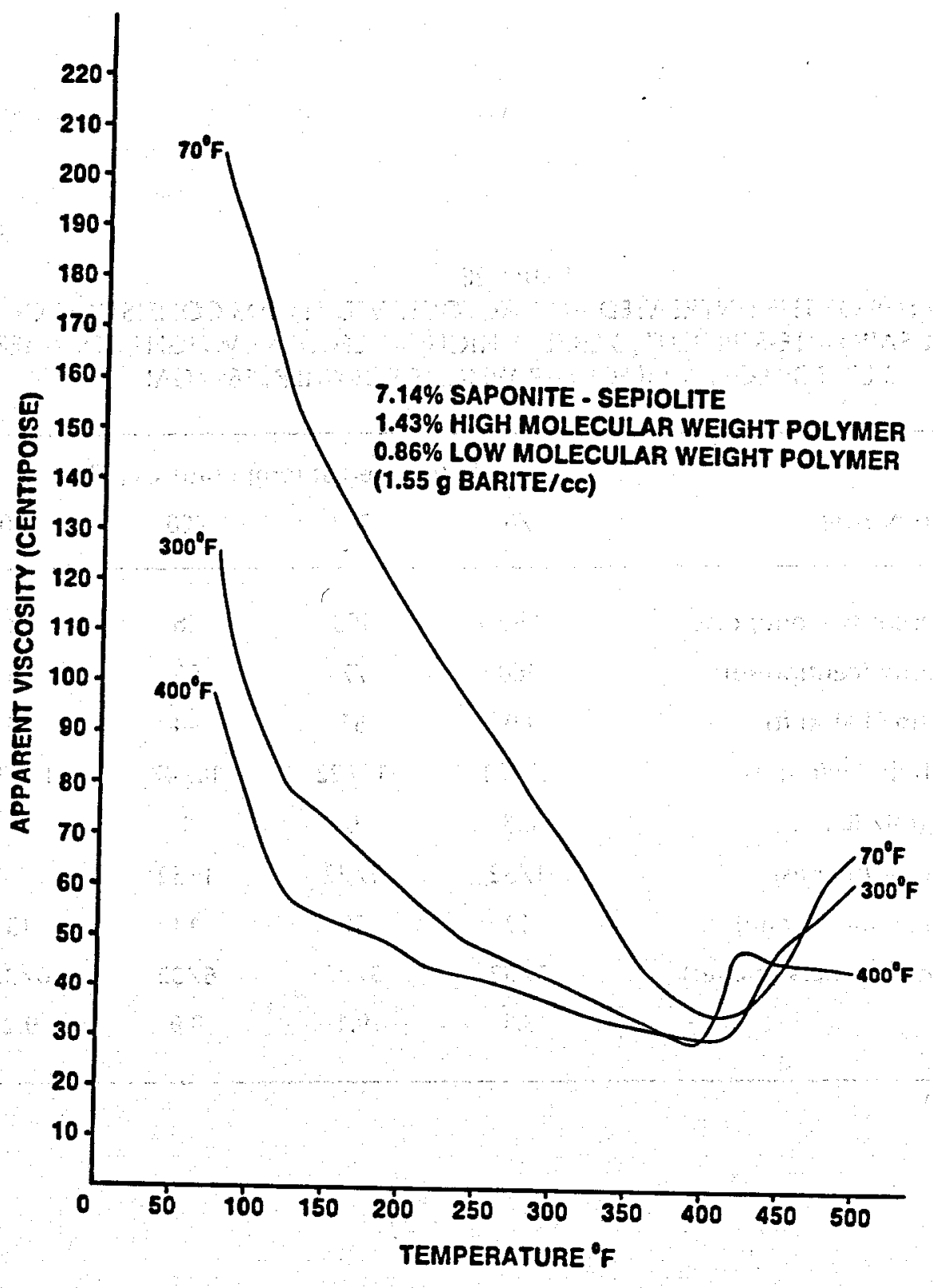

Figure 31. Viscosity profiles of Fluid E after autoclaving at various temperatures. 
TABLE 26

PROPERTIES OF THE UNTREATED AND AUTOCLAVED FLUIDS CONSISTING OF 25 LB/BBL SAPONITE-SEPIOLITE, 5 LB/BBL HIGH MOLECULAR WEIGHT POLYMER, 3 LB/BBL LOW MOLECULAR WEIGHT POLYMER, 16\#/GAL

\begin{tabular}{|c|c|c|c|c|}
\hline \multirow[b]{2}{*}{ Fluid Properties } & \multicolumn{4}{|c|}{ Autoclaved at temperatures $\left({ }^{\circ} \mathrm{F}\right)$} \\
\hline & 70 & 300 & 400 & 500 \\
\hline Apparent Viscosity (centipoise) & 190 & 103 & 88 & 81 \\
\hline Plastic Viscosity (centipoise) & 160 & 77 & 66 & 58 \\
\hline Yield Point (lb/100 sq ft) & 60 & 51 & 44 & 45 \\
\hline Gel Strength (lb/100 sq ft) & $29 / 63$ & $13 / 22$ & $16 / 47$ & $12 / 25$ \\
\hline API Filtrate $(\mathrm{ml} / 30 \mathrm{~min})$ & 0.5 & 0 & 1 & 2 \\
\hline Cake Thickness (inches) & $1 / 32$ & $1 / 32$ & $1 / 32$ & $1 / 32$ \\
\hline HP-HT Filtrate $(\mathrm{ml} / 30 \mathrm{~min})$ & 12 & 16 & 14 & 18 \\
\hline HP-HT Cake Thickness (inches) & $5 / 32$ & $5 / 32$ & $6 / 32$ & $6 / 32$ \\
\hline $\mathrm{pH}$ & 9.1 & 9.1 & 8.9 & 9.2 \\
\hline
\end{tabular}




\section{CONCLUSIONS}

A satisfactory mud system can be formulated using a saponite/sepiolite blend as the primary viscosifier. This blend can be added to a variety of make-up waters to give good hole cleaning capacity and drilling efficiency during spud-in and upper-hole drilling operations. The saponite/ sepiolite blend is easier to use and more proficient than bentonite partially hydrolyzed polyacrylamide blends. As solids increase (i.e. drill solids and/or by the addition of weighting material), the rheology of saponite/sepiolite blends can be controlled by the addition of low molecular weight polyacrylates and copolymers of these acrylates. In the case of potassium based systems, potassium neutralized salts of these polymers can be used to keep sodium at a minimum.

It is essential to keep fluid loss values at a minimum during drilling, therefore, the addition of high molecular weight polyacrylates or polyacrylamides can be used to control both fluid loss and theological properties in most systems. For highly contaminated systems, sulfonated copolymers can be used to control rheology and fluid loss properties instead of, or in addition to the above polymers.

These fluid formulations can be used from low to ultra- high temperatures, and from low to high weights using a variety of weighting materials. Therefore, this system is more resistant to temperature, contamination. carbonate and cementing problems than conventional bentonite-based systems.

A saponite/sepiolite blend can be operated in a pH range from 7.0 to 12.5 . It is important to understand the reactions of fluids run at low pH values, first of all because the chemistry is different from those fluids run at high $\mathrm{pH}$ values, and secondly, low pH ranges give better stability to both the system and the borehole wall.

This system is low in toxicity and contains no heavy metals. It is an ideal system to use where formation evaluation is critical, and where formation 
damage needs to be held to a minimum.

In the very final analysis, this study shows that a drilling fluid can be designed, operated, monitored, and maintained by using the following constituents:

1. Water (various kinds).

2. Saponite/sepiolite.

3. Low molecular weight deflocculants.

4. High molecular weight fluid loss additives.

5. Weighting material (barite or iron oxide).

This fluid system can be used to drill any borehole requiring temperature stability up to $600^{\circ} \mathrm{F}$, weights up to $18 \mathrm{lbs} / \mathrm{gal}$, low fluid loss values, optimum rheology and fluidity under static conditions for tripping, coring, logging and running pipe. By adjusting the above constituents as drilled solids are incorporated into the system; satisfactory parameters for drilling fluid properties can be obtained in any given situation.

This system lends itself to easy understanding, clear chemical control and interpretation, good shale stability, as well as temperature stability. There are no internal products that will temperature degrade and cause problems with rheology or fluid loss control. The components of this system have been thoroughly studied versus temperature so that core evaluation can be enhanced and differentiated from the components of the system itself. 


\section{REFERENCES}

Carney, L. L. and Meyer, R., 1976, A new approach to high temperature drilling fluids. Soc. Pet. Eng., SPE 6025.

Gray, G. R., Darley, H. C. H., and Rogers, W. F., 1980, Composition and properties of oil well drilling fluids. Gulf Publishing Co., Houston.

Guven, N. and Carney, L. L., 1979, The hydrothermal transformation of sepiolite to stevensite and the effects of added chlorides and hydroxides. Clays and Clay Minerals, v. 27 , no. 4, pp. 253-260.

Guven, N. and Carney, L. L., 1979, Investigation of changes in the structure of the clays during hydrothermal study of drilling fluids. Soc. Pet. Eng., SPE 7896.

Guven, N., Carney, L. L., Lee, L. J., and Bernard, R.P., 1982 , Clay based geothermal drilling fluids. Final report for Sandia Contract \#13-5104.

Guven, N., Carney, L. L., and Panfil, D. J., 1988, High temperature behavior of saponite fluids and contributions of polymers to the fluid properties. Final report for Sandia Contract \#215352.

Hang, P. T. and Brindley, G. W., 1970, Methylene blue adsorption by clay minerals. Clays and Clay Minerals, v. 18, pp. 203-212.

Magcobar a Division of Dresser Industries, INC., 1972 , Drilling fluid Engineering Manual. Houston, Texas.

Nevins, M. J. and Weintritt, D. T., 1967, Determination of cation exchange capacity by methylene blue adsorption. Amer. Ceramic Soc. Bull., v. 46, pp. 587-592.

Post, J.L., 1984, Saponite from near Ballarat, California: Clays and Clay Minerals, v. 32, pp. 203 - 212. 
Roseland, D., 1980, Rules-of-thumb aid mud-solids control.

Oil \& Gas Jour., pp. 166-167.

Savins, J. G. and Roper, W. F., 1954, A direct indication viscometer for drilling fluids. API Drill. Prod. Proc.,

pp. 7-22.

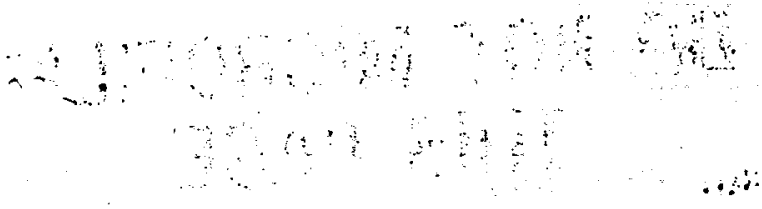




\section{DISTRIBUTION}

Tom Anderson

Drilling Fluid Consultants 17726 SW Overlook Ln.

Lake Oswego, OR 97034

Ed Bingman

Shell Oil Company

Two Shell Plaza

P. O. Box 2099

Houston, TX 77001

Jim Combs

Geothermal Resources Int'1., Inc.

1825 S. Grant, Suite 900

San Mateo, CA 94402

Larry Diamond

Smith Dyna-Drill

P. O. Box C-19576

Irvine, CA 92713

John E. Fontenot

NL Petroleum Services

P. 0. Box 60087

Houston, TX 77205

Mel Friedman, Dean

Texas A\&M University

Dept. of Geosciences

College Station, TX 77843

Dr. Necip Guven (30)

Dept. of Geosciences

Texas Tech University

Lubbock, TX 79409

James Langford

Security Division

Dresser Industries

P. 0. Box 2467

Dallas, TX 75224

B. J. Livesay

Livesay Consultants

2616 Angel1 Ave.

San Diego, CA 92122
Ed Martin

Mobil Research \& Development Corporation

Dallas Research Center 13777 Midway Rd.

Dallas, Texas 75224

Larry Matson

Stratabit

600 Kenrick, Suite Al

Houston, TX 77060

Gene Polk

P. 0. Box 280

Sandia Park, NM 87047

Steve Pye

UNOCAL Geothermal

461 S. Boylston

Los Angeles, CA 90017

George P. Tennyson DOE/ALO

P. O. Box 5400

Albuquerque, NM 87115

U. S. Dept of Energy (3)

Geothermal Technologies Div.

Attn: Lew Pratsch Gladys Hooper Marshall Reed

Forrestal B1dg., CE-324

1000 Independence Ave., SW

Washington, DC 20585

3141 S. A. Landenberger (5)

3151 W. I. Klein (3)

3154-1 C. L. Ward for DOE/OSTI (8)

6200

6252

6252

6252

6252

8524

G. E. Loeppke

J. R. Wackerly 